\title{
HAMBRE, PESTE Y GUERRA: \\ LOS EMBATES DE LA MUERTE \\ EN EL CONDADO DE COCENTAINA (1609-1709).
}

\author{
Por Primitivo J. PLA ALBEROLA
}

Universidad de Alicante

El análisis de la mortalidad es el que tradicionalmente ha despertado un mayor interés entre los estudiosos de la población. En buena medida es, o mejor ha sido, el motor que ha hecho evolucionar a la demografia como ciencia, de forma que sus métodos se han impuesto en el análisis de otras variables poblacionales hasta fechas recientes. En palabras de Chaunu, «la demografía nació de la cifra y de la muerte, de las tablas de mortalidad en tiempos de peste y de los cálculos acerca de la esperanza de vida»(1).

Pero la muerte no siempre ofrecía los mismos perfiles. Las gráficas de defunciones que los registros parroquiales permiten elaborar tienen un pulso nervioso, con incrementos particularmente importantes en el número de óbitos que se suceden de forma periódica.

A fame, peste et bello, libera nos Domini. Así reza una letanía que resume el permanente temor de nuestros antepasados ante el azote de los Jinetes del Apocalipsis. Si los niveles habituales de la muerte dejaban ya unas magras espectativas de crecimiento demográfico, las ganancias acumuladas durante años podían consumirse cuando la parca señoreaba en una sociedad dejada de la mano de Dios.

Es la razón por la que se suele diferenciar entre una mortalidad ordinaria y otra de carácter extraordinario. Una distinción que es interesante mantener, dado el discutido papel que las crisis de mortalidad tuvieron en la evolución de los efectivos de la sociedad y que su presencia, tipología y frecuencia nos pueden informar de algunas características básicas de las poblaciones en estudio, y ello pese a que la frontera entre lo habitual y lo excepcional sea controvertida(2)

Y el estudio de la mortalidad extraordinaria constituye el objeto de estas páginas, centrando nuestra atención en un siglo definido en términos de crisis -el 
Seiscientos-y en un área -el condado de Cocentaina- donde tuvieron especial incidencia toda una serie de factores adversos que son citados para describir con tintes sombríos este período de nuestra historia: la expulsión de los moriscos supuso la pérdida de las tres cuartas partes del vecindario del condado, una pérdida que no fue fácil de cubrir pese a las perspectivas optimistas abrigadas en los primeros momentos; la detracción señorial contemplada en las cartas pueblas firmadas en los años inmediatos a la expulsión es de las más elevadas del reino, razón por la que Muro sería uno de los focos de la Segunda Germanía en 1693; la villa cabecera del condado - que ya pasaba por momentos difíciles en 1609- vio desarticuladas las bases económicas de su anterior prosperidad -la manufactura textil y el comercio- por el grave endeudamiento que arrastró durante toda la centuria, lo que condujo a la alienación de sus rentas, a la debilitación de sus posturas reivindicativas frente al conde y a un emprobrecimiento de su espectro social. ${ }^{(3)}$

Al hablar de las «mortalidades» del pasado - por utilizar un término habitual entre sus contemporáneos y que hace referencia a su característica más inmediata y visible- entramos en el tiempo corto, casi el elemento fáctico, de la historia de la población, sin que de ello resulte detrimento alguno de su importancia: su estudio interesa no sólo en su vertiente demográfica, sino, además, por las reacciones suscitadas en unos hombres ante momentos particularmente difíciles en los que está en juego su propia supervivencia. Así,las "crisis demográficas» han sido definidas como «le fait majeur de la démographie d'Ancien Régime»(4); una expresión sobre la que pesa de forma determinante el Beauvais de Goubert, $\mathrm{y}$ que otros muchos autores se negarían a suscribir.

El estudio de las crisis de mortalidad ha originado una importante bibliografía desde el ya clásico trabajo de Meuvret, pero está fuera de lugar el esbozar aquí un estado de la cuestión, otros autores lo han hecho en fechas recientes, y a su trabajo me remito ${ }^{(5)}$. Sin embargo, sí que conviene apuntar dos cuestiones que interesen al posterior desarrollo del tema.

Una primera se refiere a la misma identificación del objeto en estudio. Dejando aparte precisiones semánticas, la calificación de una punta de mortalidad como crisis o no, según los valores que alcance, depende en buena medida de los criterios utilizados para su estimación, y de ellos también depende la posterior evaluación de su incidencia. Han sido propuestas distintas fórmulas, más o menos elaboradas, sin que ninguna haya quedado exenta de criticas ${ }^{(6)}$. Por ello, en un estudio localizado como éste, donde las parroquias tienen una entidad poblacional tan dispar y la mortalidad ordinaria registra diferencias significativas entre las distintas localidades y a lo largo del tiempo, prefiero utilizar un índice sencillo que pone en relación las series de bautismos y defunciones. Centraré mi atención en los años en los que el número de los difuntos supere el medio de los bautizados. Se trata de identificar aquéllos en los cuales las expectativas de futuro de una población resultan comprometidas por un saldo negativo, y para evitar el efecto distorsionador de las oscilaciones del número de los nacidos - creando aparentes 
crisis y enmascarando otras - opero sobre una media de bautismos de nueve términos centrada sobre el quinto (4.1.4); sin perder de vista la posible significación de alguna de las bajas pronuncidas de nacimientos como atribuibles a una crisis más o menos larvada. Después, la intensidad quedará definida por las habituales lasas de mortalidad.

Cabe criticar lo inadecuado del año civil para delimitar el campo de observación. Las crisis definidas por Meuvret (7) cabalgan sobre dos años consecutivos, $y$ algunos factores epidémicos tienen una configuración estacional semejante(8). Con el fin de obviar tal inconveniente he calculado también el número de concepciones, matrimonios y defunciones por años-cosecha-delimitados por las fechas de recolección del cereal panificable por excelencia: el trigo- que se extenderán desde principios de julio hasta fines de junio del año siguiente ${ }^{(9)}$.

Desde luego, tampoco es posible calcular las tasas de mortalidad de forma ortodoxa, pues desconocemos los totales de población. En algunos momeritos cabe recurrir a vecindarios elaborados en fechas próximas, pero dado lo aleatorio de su aparición y su siempre discutible fiabilidad, es mejor evaluar los efectivos totales a partir del número medio de bautizados. Así, estimaré el total de habitantes suponiendo una tasa uniforme de natalidad del $40 \% 0$, lo que significa aplicar un coeficiente mult iplicador de 25 , y a partir de la media de nueve años antes mencionada. No he considerado oportuno eliminar de la misma los años que difieren más de la media, porque los bautismos tienen una variabilidad menor que las defunciones, son afectados de forma sólo indirecta por las crisis de mortalidad y, frecuentemente, en un doble sentido.

De todas formas, quedan algunos problemas que no he creido preciso corregir - la pretensión de alcanzar una mayor exactitud no puede ser más que ilusoria - aunque convenga tenerlos presentes. Al tomar un mismo coeficiente multiplicador para todas las parroquias, en la medida que las de características más urbanas registren tasas de natalidad menores - por la mayor importancia de célibes y la presencia de transeúntes sin sus respectivas familias - resulta una subevaluación del número de habitantes, y así se estarán calculando tasas de mortalidad por encima de las realmente alcanzadas. Pero el inconveniente más grave, y de difícil solución, es que en las mayores crisis - como veremos: la peste de 1648 y la Guerra de Sucesión- tienen lugar desplazamientos de población cuya importancia no es posible conocer. Cuanto mayor haya sido la fuga de habitantes del área de cobertura de los registros, y reducido por tanto los efectivos de población sobre los que se basan nuestras observaciones, mayor será la subestimación de la mortalidad, por aplicar en el cálculo de las tasas un divisor superior al número real de habitantes en los momentos de la crisis.

La segunda cuestión que antes mencionaba atañe a la caracterización de las crisis y al intento de dilucidar cuáles son las causas de las mismas. La conocida trilogía de hambre, peste -en su sentido más lato-y guerra está en el origen de la mayoría de las mortalidades de los tiempos modernos, y sólo cabría añadir la esporádica incidencia, muy localizada, de catástrofes de diversos tipos, como los terremotos ${ }^{(10)}$.

Las indicaciones contenidas en las actas de defunción apenas son utilizables para identificar el origen de las sobremortalidades, y ello llevó a intentar hacerlo 
a través de la distribución estacional de los óbitos y el impacto registrado en las series de bautismos y matrimonios: diferirían según fuese una mortalidad atribuible a factores epidémicos o a las crisis de subsistencias.

Pero los esquemas planteados en los primeros momentos han resultado insuficientes para cubrir el objetivo que perseguían: debemos hablar mejor de crisis mixtas, en tanto que el hambre suele venir acompañada por epidemias que guardan con ella estrecha relación y también las mortalidades epidémicas puras pueden alterar el discurrir normal de las concepciones efectivas y la celebración de matrimonios ${ }^{(11)}$.

\section{LAS EPIDEMIAS DE PESTE EN EL CONDADO DE COCENTAINA}

La peste, a lo largo del período en estudio, representa una de las grandes catástrofes a la que están expuestas las gentes del condado. Los simples rumores que sobre ella circulan, la certidumbre de su proximidad, cuánto más la epidemia declarada, ponen repetidas veces en tensión los mecanismos de defensa tanto a nivel individual como colectivo.

La peste, con el hambre y la guerra, forman el sustrato de los miedos de la sociedad de la época. Con razón habla de ella Bennassar como de «un grand per-

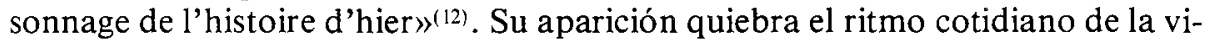
da en los lugares afectados. Son puestos a prueba la cohesión de la sociedad, la fuerza de los vínculos de solidaridad, la responsabilidad de los grupos rectores, la misma confianza en las creencias religiosas y, en un nivel más concreto, en la del poder intercesor de determinados santos tutelares ${ }^{(13)}$.

Todos estos temores, de forma periódica, encuentran su reflejo, aunque de una manera si se quiere formal, en los arrendamientos de diezmos, de los derechos señoriales y de los municipales.

Los arrendamientos de diezmos estipulan

«(...) que los dits venedors (arrendadores) no sien tenguts ni obligats a tala alguna feta o fahedora per rahó de guerra, ni dany, ni a refacció alguna per rahó de pedra, neula, diluvi, esterilitat, seca, mal temps, mortaldat, tempestad, lagosta o altre qualsevol sinestre, cas cogitat o incogitat que dir y nomenar se puga, així per permissió divina com per malícia dels hómens causat o causadors $(\ldots)^{(14)}$

Con tan eximios valadores, la cláusula se extiende en los contratos de arrendamiento de derechos dominicales e, incluso, en los más modestos, relativos a tierras arrendadas por particulares. En los arrendamientos del condado de 1497, 1515 y $1516^{(15)}$ es reconocida al arrendatario la capacidad de rescindir el contrato en caso de "guerres, debats o mortaldats» que produzcan una mengua del valor de las rentas. La mención a una renuncia a cualquier rebaja por estas causas, tal como arrienda el arzobispo los diezmos, figura por primera vez en 1626 y $1635^{(16)}$. No constará en 1644 , el año que hubiese sido necesario, aunque quizá se regulase por las escrituras anteriores. Sin embargo ya no faltará, explícita o implícitamente, a partir de 1644; pero con la significativa modificación de que en caso de peste, langosta o guerra que produjese una reducción en el valor de las rentas superior a 500 libras, será rebajada su cuantía según la estimación de ex- 
pertos, manteniéndose la renuncia total a menoscabos sólo en los casos de inclemencias climatológicas ${ }^{(17)}$. La peste de 1648 deja aquí la huella de su paso por el condado.

El temor a la peste y a la guerra no podía dejar de aperecer también en los arrendamientos de derechos municipales: son sucesos que, a menudo, inciden con más gravedad en las aglomeraciones urbanas y, además, interrumpen el comercio, actividad que interesa especialmente para la rentabilidad de esos derechos. En los Capítols de les imposicions de la vila de Cocentayna de $1457^{(18)}$ no aparece mención alguna a la peste. Quizás sean las sucesivas epidemias de 1459$62,1465-67$ y $1475-78^{(19)}$ las que decidirán al consell a la incorporación en 1489 de una cláusula que contempla este supuesto: si en el año del arrendamiento o el posterior se registran en la villa «mortaldats», por las cuales huyan un número superior a diez familias, pueden los arrendatarios, y mientras dure su ausencia, rescindir el contrato ${ }^{(20)}$.

\subsection{Algunos precedentes}

Antes de entrar en las epidemias que más nos interesan aquí por su cronología, quiero ofrecer algunas referencias dispersas sobre las pestes de la centuria anterior, tanto porque no son fáciles de conseguir y pueden interesar a trabajos más amplios, como porque ponen de relieve ciertas constantes que no dejerán de aparecer en los brotes ulteriores.

El padre Arques, cuyos manuscritos serán citados repetidas veces en este trabajo, resume un acta notarial de 28 de mayo de $1496^{(21)}$, por la cual el arrendatario de las sisas de Cocentaina, dado que

«(...) en dit contracte aseguraren de morts, ço és que morint-se en la dita vila de pestilència, e per causa de les dites morts exirien deu casades fora lo terme de la dita vila, los dits honorables jurats remprearien e cobrarien dites imposicions. E per quant tota la gent de la dita vila estiga y stà comoguda e avalotada de anar-se'n del terme de aquella per causa de dites morts, com per speriència se vega que tots trosen la roba per anar-se'n per que dix que restituhia, dexava e derinclia les dites imposicions (...)».

Hay explícita mención a muertos por «pestilència», pero los jurados niegan la rescisión del contrato: «dixeren y respongueren que tota ora e quant deu casades exerien fora lo terme farien ço que deguen de justícia». La desbandada aún no había comenzado.

Las noticias sobre la peste de 1522 apuntan a una reacción similar. A pesar del bando publicado el 20 de octubre con el objeto de aislar la villa de los focos de Ia epidemia, ésta infectó a los contestanos a fines de ese año y durante el siguiente, sin poder precisar más las fechas. Se conoce la muerte de apestados, la huida de algunos vecinos a Alcoy - donde no parece que corriesen mejor suerte-y que en octubre de 1523 todavía hay una casa, al menos, cerrada por los jurados al haber muerto allí apestados ${ }^{(22)}$.

El comercio vuelve a ser el principal perjudicado cuando en 1558 el «mal contagiós» se apoderó de Valencia y otras partes del reino que no especifica. Así, 
como el mercado semanal convoca a mucha gente y «se poría fàcilment pegar aquest mal contagiós», acuerdan suspenderlo durante los meses de julio y agosto, asumiendo las pérdidas de los arrendatarios de las sisas por las cantidades que dejasen de percibirir ${ }^{(23)}$. Desde luego, es escaso el reflejo que una epidemia tan próxima alcanza en los libros de consells.

Otro será el caso de la epidemia de 1589, más lejana, y quizá por ello no tengan reparo en hablar de «peste». El 30 de julio es publicada una crida precaviendo contra los individuos y ropas que provengan de las zonas apestadas, pero las localidades que se mencionan son Barcelona, Igualada, Santa Perpetua de Moguda y otras, todas ellas de Cataluña ${ }^{(24)}$.

Son pocas las alusiones a la peste recogidas para tan dilatado período. Una razón, sin duda, está en que no he procedido a un vaciado sistemático de la documentación de la época, pero también hay que hablar de la menor riqueza de datos de los libros de consells, la fuente aquí utilizada, conforme nos remontamos en el tiempo, por cuestiones que ahora no vienen al caso.

\subsection{La peste de Játiva}

Tras esta rápida mención de algunos datos sobre epidemias anteriores, entramos en el estudio de las tres grandes pestes del Seiscientos que afectaron, con mayor o menor intensidad, al reino de Valencia.

La primera de ellas es la que asoló la península entre los años 1596 y $1602^{(25)}$. Es una peste fundamentalmente castellana, pero que penetró en algunas comarcas interiores del reino a través de la ruta comercial que unía los talleres de seda en Toledo con las zonas productoras valencianas ${ }^{(26)}$. De todas formas, su área de expansión es poco conocida. Denominada la peste de Játiva -porque castigó duramente a esta ciudad-, por estar en una encrucijada de rutas, se temió que fuera incontrolable en su marcha hacia el sur y en la infección de la capital. La referencia más citada de esta peste es la que hace Perales: afectaría a Onteniente, Alcoy, Agres, Agullent, «y en general todos los pueblos de las comarcas montañosas»; Valencia, según una piadosa tradición sería preservada por su patrono San Vicente, aunque Perales habla de que se llegaron a producir algunos casos ${ }^{(27)}$. Vemos que, según este autor, la peste infectó las comarcas próximas al condado de Cocentaina.

En los libros de consells la peste aparece ya a principios de julio de 1599 . El temor a la epidemia se concreta el día 7 -según el acta de 21 del mismo mespor la llegada de unos castellanos con cargas de lana procedentes de zonas infectadas; a los cuales, habiendo desoído las órdenes de que abandonasen Cocentaina, les es quemada la mercancía. El mismo día, el consell acuerda celebrar la fiesta de San Roque, abogado contra la peste, tal como habían hecho en otras villas; y también los arrendatarios de las sisas presentan la acostumbrada solicitud de refacción por el daño causado con la paralización del comercio, aunque sólo está interrumpido con Castilla y Barcelona, pero no con localidades del reino(28).

Falta el libro de consells que comprende los años 1600 a 1605; así, es imposible seguir de forma adecuada las medidas tomadas para prevenir la invasión de la epidemia y, en su caso, durante la misma. Hemos de referirnos de nuevo a las no- 
tas del padre Arques, quien, si bien tampoco pudo consultar los consells de esos años, tuvo acceso a otra documentación ahora desaparecida, y se interesó por la epidemia al estar relacionada con el origen del patronazgo de San Hipólito en Cocentaina.

De un antiguo libro de cabreves copia Arques el sorteo efectuado con el fin de nombrar un santo patrón que les protegiese del mal, que ya afectaba a los lugares circunvecinos. El ritual seguido es el acostumbrado, y no falta la intervención milagrosa. De una bolsa donde habían depositado los nombres de varios santos en sus respectivas bol.letes, una mano inocente extrae la que resulta corresponder a San Hipóilito:

«lo qual, oït per lo poble y gran concurs que allí estava, dixeren que no volien tal sant, per quant no el conexien, y que axí en tragueren altre dels que en dita bolsa avien possat $)^{(29)}$.

La voluntad popular no se conforma con los designios divinos que, al cabo, vienen a imponerse cuando en una segunda y tercera extracción vuelve a aparecer San Hipólito.

A esta decisión siguen las rogativas y demás actos religiosos, sobre los que no interesa extenderse; pero sí decir que, según todos los indicios, Cocentaina se vio libre ese año de la peste. Así lo asegura el documento citado, aunque su redacción, al ser de mediados del XVIII, pueda suscitar alguna reserva, y lo corrobora una noticia contenida en el Libro Racional de la parroquia de Santa Maria del año 1600:

«Est any fonch lo any de la pesta, que y ague en aquest regne, y en Cocentayna no $n^{*} y$ ague, a Déu gràcies (30). $^{(30}$.

Y tampoco las series disponibles de bautismos y matrimonios registran oscilaciones anormales que hagan pensar en una epidemia.

\subsection{La peste de 1647 a 1652}

El paso de la peste de mediados de siglo por el condado es el que nos ha legado un mayor número de testimonios - aunque referidos en su mayor parte a Cocentaina - circunstancia que permite esbozar algunos aspectos de ese cúmulo de reacciones desatadas por la epidemia en cualquier sociedad de la época, a la vez que estimar con aproximación su impacto demográfico.

No deja de ser lógico que nos haya llegado un mayor volumen de documentación de esta "segunda ofensiva» de la muerte en el Seiscientos. Si la peste de 1596-1602 tuvo una incidencia localizada en las comarcas del interior, sin llegar a afectar a Cocentaina; y otros brotes posteriores, como los de 1629-1630(31) en Cataluña o los de 1637 en Almería, quedaron aislados geográficamente, la de 16471652 campea a lo largo y ancho de la geografía valenciana - desde su centro difusor en la capital (32) - , aunque no podemos todavía ofrecer unas rutas e identificar las localidades afectadas, ni tampoco más balance de su paso que el general transmitido por los autores de la época como Pruñonosa, Gavaldá o Arcayna, junto a algunas estimaciones de carácter local(33). 


\subsubsection{Cronología de la epidemia}

En Cocentaina, el temor siempre latente al azote de cualquiera de los Jinetes del Apocalipsis se acentúa con las alarmantes noticias llegadas desde Valencia, donde la peste cobra sus primeras víctimas en julio de 1647 .

Las medidas son las habituales: precaución, alerta ante los avances de la enfermedad, aislamiento de cualquiera que pudiese ser portador del mal.

En el consell de 12 de septiembre de 1647 aparece por primera vez con extensión el tema de la peste, exponiendo el jurat en cap

«que en la ciutat de Xàtiva han tancat los portals, axí seria molt bo que es fés en Cocentayna. Y que algunes persones havien vengut de València, que si volien que els fessen exir de Cocentayna fins tant està vist lo que serà. Nemine discrepante: que no aculgen en Cocentayna a ningun, y que si ni y a en Cosentayna que ixquen ${ }^{(34)}$.

Y el mismo consell procede al nombramiento de una junta con poderes amplios, compuesta por los magistrados locales, diecisiete prohombres, cura, vicario y cinco clérigos. Aunque no se indique de manera expresa, sus funciones son las de prevenir la epidemia; y con idéntico objeto se implanta un registro de las patentes de sanidad, para comprobar la validez de las presentadas por quienes pretendían entrar en la villa y expedir el correspondiente bol.latí a los que de ella partiesen $^{(35)}$.

Las primeras actuaciones son inmediatas y expeditivas. Interrogan a un $t r a-$ giner proveniente de Valencia acerca de si en la capital hay «mal contagiós». A pesar de su respuesta negativa, le conceden un plazo de dos horas para abandonar Cocentaina ${ }^{(36)}$. Desde entonces es puesta en práctica la expulsión de las personas procedentes de Valencia, siendo la causa principal de la génesis de un conflicto de competencias con el gobernador.

Noticias indirectas hablan de que la máxima autoridad señorial en el condado había mandado a los magistrados locales inhibirse en la cuestión «del morbo y mal contagiós que es preten y ha en la ciutat de València». Y el conflicto se endurece cuando pretenden expulsar de la ermita de San Cristóbal a la viuda e hija del anterior procurador general. Les manda entonces, pena de 200 libras, permitan a las dos mujeres vivir allí, pues lo dispuesto

«és contra tot orde de justícia y rahó natural, per haver habitat en dit puesto altres persones que han vengut de dita ciutat, majorment estant com es deu saver il.leses de tot mal contagiós, y per ser dit puesto acomodat y apartat de la contribució de dita vila y no haver altre puesto més acomodat per a semblants persones $\rangle^{(37)}$.

Destaca la extensión alcanzada por la diáspora de los vecinos de una población atacada por la peste. También el consell de Muro había asignado guardas a un huido de Valencia ya en diciembre de 1647 , y podemos encontrar vecinos de la capital hasta en los confines del reino: algunos de ellos, los que no huyeron a tiempo, mueren de peste ${ }^{(38)}$. Semejante dispersión de potenciales portadores del temible mal evidencia que las autoridades no tomaron a tiempo medidas eficaces para atajar su extensión, y puede explicar la posterior aparición de la epidemia en puntos alejados del foco original. 
Con la llegada del invierno parece que la preocupación decrece. También quizá sea el momento de preparar mejor las medidas necesarias, pues da la impresión de que el primer embate del miedo cogió desprevenida a la administración municipal. Por de pronto, sin conocer cuándo se llega a un acuerdo, resuelven las cuestiones de competencias y, al año siguiente, la máxima autoridad ante la peste recaerá en una junta de elects, compuesta por los magistrados locales y cuatro representantes del conde.

Posteriores informes hablan de que la peste va ganando terreno: Alicante y Gandia caen en enero, Orihuela en febrero, el resto del Bajo Segura, Aspe y Elche en marzo, Crevillente a fines de abril( ${ }^{(39)}$.

Ante la proximidad de los ejércitos de la muerte es declarado el estado de sitio en todas las localidades, y las viejas murallas, allí donde las hay, vuelven a cumplir su función de defensa, pero ahora contra un enemigo mucho más temible. Desde el circuito murado, si bien no se podrá impedir la entrada de los aires «pútridos» y «corrompidos» que las extendidas doctrinas aeristas identifican como el origen de la enfermedad, sí se podrá controlar un tránsito de hombres y mercancías, medida que la experiencia muestra como único remedio eficaz contra el terrible mal. Así, las murallas de Cocentaina son reforzadas y las puertas tapiadas, excepto dos, para ejercer un mejor control de las entradas y salidas. Además, los ediles toman las medidas necesarias sobre avituallamiento y asistencia médica para resistir un cerco de imprevisible duración.

Desconfiando de las fuerzas de los hombres, los contestanos recaban las ayudas de los santos valedores, a cuya intercesión atribuyen la salvación en otros momentos de peligro. El uno de mayo es llevada en Cocentaina la imagen de Nuestra Señora del Milagro a la parroquia de Santa María, celebrándose diversos actos religiosos. Ante el desarrollo que la epidemia alcanza, el 28 de junio, a instancias de los jurados nuevamente,

«per les necesitats del present regne y en particular per lo mal contagiós que al present patien moltes viles y pobles, es determina portassen en procesó la imatge de Nostra Senyora del Milacre a la present esglèsia [de Santa María] y es celebràs una dobla cantada de Nostra Senyora, etcètera $)^{(40)}$.

Sin embargo, estas últimas rogativas son ya in extremis, pues, aunque no lo reconozcan, en la villa se ha declarado la epidemia. La actuación de los jurados había sido expeditiva contra cualquier tránsito que pudiese introducir el contagio. La junta de elects había mandado pregonar que nadie entrase ni saliese de la villa, ni trajese ropa sin la previa inspección de los jurados ${ }^{(41)}$. La dureza de las penas impuestas a los transgresores de las disposiciones son un fiel reflejo del miedo a la peste. Sirva para ello un ejemplo recogido en los libros de consells.

Francisco Martí, labrador residente extramuros de Cocentaina, declara el 23 de junio, bajo juramento, que tiene en su casa dos fardos de lienzo peligrosos por proceder de Alicante, «infecta que estava y està del mal del contagi». La trayectoria de las telas refleja la contraposición entre los intereses particulares y los públicos; entre el valor de una mercancía y su peligrosidad como potencial vehículo transmisor de la epidemia. De Alicante habían sido llevados a Alcoy por un vecino de esta localidad, quien -obligado a cumplir la cuarentena y ante el temor 
«que dit Silvestre tenia de que -ls jurats de la vila de Alcoy no la cremassen»-la remitió a Martí hacía ya mes y medio. La decisión de los jurados es que sean quemados los dos fardos junto con la ropa de quien osó transgredir la normativa de la peste, siendo además desterrado a perpetuidad de la villa y su término(42).

Sin embargo, todas las medidas precautorias resultaron ineficaces. El mismo día que Martí debía salir para su destierro, se recibió la declaración jurada de un testigo que, al querer entrar en Penáguila con un certificado de sanidad de Muro, obtuvo como respuesta de los guardianes

«que el bol.letí era bo, però per quant auria passat dit Bernat Garri-

do per la present vila de Cocentayna no $l$ volgueren dexiar entrar $\gg^{(43)}$.

$\mathrm{Y}$ habían sido más explícitos los mismos guardias el día anterior, según declaración prestada el 28 de junio, pues a Miguel Mora no lo dejaron entrar «per ço que li dixeren les guardes que la present vila de Cocentayna estava infecta del mal contagiós $)^{(44)}$.

Como solía suceder, la declaración de peste en cualquier localidad era hecha pública antes por los concejos limítrofes que por sus propias autoridades. Esta situación era fruto de lo contrapuesto de sus respectivos intereses: los primeros, a la menor sospecha, declaraban a sus vecinos -en este caso a Cocentaina - como apestados, derivándose de ello el aislamiento en un intento de precaverse del mal del contagio. Los propios ediles, en cambio, intentarían dar, mientras ello fuera posible, una imagen de tranquilidad, que en esos momentos era tanto como decir de salud. Se trataría entonces de aislar los casos detectados, esperando que el mal no se extendiese a todo el vecindario. En el intento de impedir la incomunicación, que de por sí podía ser tan temible como la peste ${ }^{(45)}$, las autoridades municipales podían servirse de las mismas dudas de los médicos de la época respecto si la peste se definía por unos síntomas o por el alcance de la infección ${ }^{(46)}$.

Es una situación observable en el ejemplo que nos ocupa. El 28 de junio se ruega por la salud de «moltes viles y pobles», sin que nada haga pensar que entre ellos está incluida Cocentaina, pero hacía más de una semana que Penáguila había cortado las comunicaciones. Y aunque tras finalizar la epidemia hablan de «lo mal contagiós que comensa en los darrers dies del mes de juny passat» ${ }^{(47)}$, un relato contemporáno de la misma, que Arques copió del Libro Racional, de una cronología algo distinta:

«En los messos del estiu passat de 1647 comensaren unes enfermetats en la ciutat de València molt rigoroses que causaren gran terror y es moria molta gent, y fonch declarat per peste y mal contagiós. Y avent-se fet en la present vila moltes diligències en possa guardes als portals, per a que de eixa manera no entràs lo dit contagi y mal (però nisi Dominus costudierit etc.) fonch nostre Senyor servit que als primers del mes de juny del present 1648 es morí una filla de Pere Agulló en lo raval repentinament. Los senyors jurats feren les diligències degudes en procurar atallar dit mal, y luego, de allí a pochs dies, moriren en lo hostal de Vicent Sespulgues dos filles y lo dit Vicent Sespulgues, $\mathbf{y}$ de allí a poch temps comenzaren a caure del mal contagiós algunes persones y es determinà es fés y nomenàs casa blanca y deputada per els que cayguesen de dit mal (...) $)^{(48)}$. 
Víctimas aisladas desde principios de junio $-\mathrm{y}$ entre las primeras, significativamente, el mesonero y parte de su familia-, incontrolable ya al terminar el mes, cuando los jurados señalan «casa blanca» -que es tanto como el reconocimiento oficial de estar la villa apestada-; la epidemia se extiende en una primera etapa hasta los primeros días de diciembre, sin poder establecer una cronología más precisa sobre los momentos en que alcanza su mayor incidencia ${ }^{(49)}$. Será en la junta de 6 de diciembre donde se acuerda remitir a una persona cualificada de la villa para que exponga a las autoridades de Jijona y Alicante el fin de la epidemia en Cocentaina ${ }^{(50)}$.

Sin embargo, es una decisión quizá apresurada, movida sin duda por el interés de normalizar los intercambios, pues o todavía era precipitado hablar de salud o la remisión de la peste no fue más que temporal. Pocos días después se habla de nuevos enfermos en la villa y el arrabal, y acuerdan volver a contratar al doctor que había atendido a los apestados hasta entonces. El contrato es desde el día doce de diciembre $y$, en un principio, por un mes $^{(51)}$; período que después se alarga hasta un total de cuarenta y nueve días, es decir, hasta la segunda mitad de enero ${ }^{(52)}$.

En repetidas ocasiones se ha puesto de manifiesto lo caprichosos que pueden llegar a parecer los trayectos por los que discurre la peste: ataca a una ciudad y la inmediata permanece sana y salva, focos aislados surgen de repente lejos de cualquier otro punto de infección. Sin salir de los límites del condado, en tan estrecho marco, encontramos el reflejo de las mencionadas irregularidades en la expansión de la epidemia. Si Cocentaina es atacada en junio, Muro -según Momblanch - resultó indemne en los primeros ocho meses del año, pese a la corta distancia $(5 \mathrm{~km}$.) que le separaba de la villa apestada.

En Muro, la peste no hizo acto de presencia hasta los últimos días de septiembre o los primeros de octubre de 1648, pues el consell celebrado el siete de este mes es el que toma las primeras medidas para el caso de que no pudiese controlarse una epidemia ya declarada. En él, el jurat en cap plantea a los asistentes

«que si acàs pasava avant lo mal que quin reperient (sic) buscarien y determinarien per a poder afavorir als que hixiran fora malats com als que staran fent la quarentena, com també pagar y sostenir lo doctor, confessor y sirurgià y tot lo demés neçessari per a dit efecte».

Y el consell acuerda utilizar una cantidad que habían tomado a cambio, pedir ayuda a la condesa, hacer un reparto vecinal tras la epidemia, nombrar a tres vecinos «que sàpien lletra» para anotar todos los productos que, de orden de los jurados, se entregasen a los enfermos - con el objeto de cobrarlos después-y, en último extremo, gastar toda su hacienda con tal de que no muriera nadie del pueblo, «ab la confianza en Déu Omnipotent y la interçesió del gloriós sen Roch $)^{(53)}$.

De la duración de la epidemia en Muro no nos han llegado más que noticias indirectas: hay contratados varios enterradores entre el diez de octubre y el ocho de noviembre; el doctor y cirujanos de la «casa blanca» prestan sus servicios entre el ocho de octubre e igual día del mes de noviembre, pero el doctor cobra aparte «por la primera visita que hizo a Muro antes de concertarse» y es de nuevo contratado entre el uno y el veinticinco de diciembre ${ }^{(54)}$. 
Para el resto de las localidades del condado no se conserva otra documentación que los registros parroquiales, y el paso de la peste sólo encuentra reflejo en los de La Alcudia, la parroquia más próxima a Cocentaina, pero no en Gayanes ni Alcocer ${ }^{(55)}$. Una situación a relacionar con el comportamiento habitual de la peste, de la cual escapan con mayor facilidad las localidades más pequeñas ${ }^{(56)}$.

\subsubsection{Una sociedad ante la muerte}

Durante unos ocho meses, entre junio de 1648 y enero de 1649 , la sociedad contestana se vio lacerada por el azote de la peste, sin que sea posible seguir puntualmente el desarrollo de las medidas tomadas en el intento de paliar los efectos de la enfermedad. No parece atribuible tal ausencia de documentación a la huida de las autoridades municipales, como sucedió en tantos otros lugares ${ }^{(57)}$, sino a que las determinaciones de la junta de elects no serían anotadas en los libros de consells, y a que la misma característica contagiosa de la peste desaconsejaría convocar a los vecinos a un consell general. Desde fines de junio, al menos ${ }^{(58)}$, no es convocado el consell general hasta el dos de diciembre de 1648, nuevamente en los últimos días del mes para dar posesión al procurador del nuevo conde, para, por fin, recobrar el ritmo normal de las asambleas desde principios del siguiente año.

Como he apuntado, los cargos municipales, al menos los más representativos, no abandonaron sus puestos; aparte de las menciones en esporádicos documentos generados durante la epidemia ${ }^{(58)}$, una prueba indirecta de su presencia se encuentra en las partidas de gastos satisfechos una vez transcurrida aquélla: un llencer percibe la cantidad de 737'5 sueldos que «se li dehuen de tanta tela se prengué de aquell en lo temps del contaxi per a bestes als jurats y demés que servien en dit contaxi» ${ }^{\left({ }^{(6)}\right.}$; $y$ los jurados son la pieza clave de la administración municipal. Otra actuación es la del gobernador, quien huye a Bocairente(61).

Las atenciones, dentro de las posibilidades, de las finanzas municipales no quedaron desatentidas. Tampoco faltaron los auxilios espirituales a quienes afrontaron sus últimos momentos. No parece que el clero abandonase a su feligresía. Sobre el secular no tengo más argumento que el favorable de la continuidad de los registros parroquiales. Aunque sí llegaron a correr rumores acerca de la huida de los religiosos franciscanos. Unos rumores infundados, según se desprende de una carta del provincial de la orden fechada el dieciocho de agosto de ese mismo año, en los momentos culminantes de la epidemia:

«La de V.R. nos sacó de una pena que nos afligía al corazón, porque corrió aquí una nueva, no sabemos quien la truxo, y era que por haver V.R. faltado al pueblo estavan los de villa tan sentidos con V.R. que les havían quitado la pitança y tratavan fundar convento de capuchinos. Pero por la de V.R. veo lo contrario; pues me dice en ella que los frayles legos se han ofrecido al servicio de los enfermos y dos sacerdotes para administrar los sacramentos, los otros para ir personalmente por las barracas a pedir limosna para socorrer a los pobres. Todo eso está bien hecho, y no han de ser sólo ofrecimientos sino obras» ${ }^{(62)}$. 
En líneas generales, las cabezas rectoras de la sociedad, con excepción del gobernador, no abandonaron la villa en sus momentos más dramáticos; cosa que no se puede decir de los particulares.

En diciembre, en una mirada retrospectiva, el escrivà de la sala habla de «los grans treballs que la present vila y particulars de aquella, del arraval y Fraga han patit per lo mal contagiós (...) obligant tancar les cases y anar-se'n casi tots los habitadors $)^{(63)}$. La huida es, desde luego, la forma más eficaz de librarse de la peste. Una precaución de tipo individual, recomendada una y otra vez por los médicos y por cualquiera que conociese la importancia real de las medidas terapéuticas de la medicina de la época: «huye presto, vete a lejos tierras y buelve tarde a la que apestada dexaste) $)^{(64)}$.

La villa se despuebla, parcialmente desde luego, pero sin que podamos saber en qué medida. Una diáspora que no era sólo resultado de la precaución sino del terror, y que no podía menos que favorecer la extensión del contagio. De todas formas, muchos contestanos no siguieron al pie de la letra esos tres preceptos enunciados. Por un lado los que se quedaron, por otro los que no huyeron a tiempo ni lo bastánte lejos, quizá por la sencilla razón de que estaban cerrados los caminos en torno a la villa apestada. El caso es que si unos encontraron su fin en la «casa blanca» (...) «altres moriren en fora, en lo camp y en les barraques y casses de les heretats, que per lo mal se'n ixqueren fora» ${ }^{(65)}$.

Pero la huida no estuvo, no podía estar, al alcance de todos, y las autoridades contestanas hubieron de enfrentarse con la epidemia ya declarada. Mercado, en un tratado sobre la peste, propone tres remedios inexcusables:

«Oro, fuego y castigo. Oro para no reparar en costa ninguna que se ofrezca. Fuego, para quemar ropas y casas que ningún rastro quede. Castigo público y grande, para quien quebrase las leyes y orden que se les diere en la defensa y cura de estas enfermedades»(66).

De actuaciones expeditivas tenemos repetidas muestras en estos años; ya fue más difícil obtener el oro para afrontar los gastos necesarios.

La hacienda municipal estaba en crisis total desde 1610 , las deudas contraídas se acumulaban y la presión de los acreedores, que repetidamente recurrían a los embargos ejecutivos, llegó a ser asfixiante pese a las sucesivas concordias firmadas con ellos. En este contexto, la paralización del cobro de las sisas municipales, la condonación de las pagas a sus arrendatarios, las mismas dificultades de las economías familiares, no hicieron sino agravar el problema. De los dispersos datos que sobre el'particular obran, se deduce que fue necesario recurrir, aparte de a las cantidades que existiesen en las exhaustas arcas municipales, a la solicitud a crédito de las medicinas necesarias y a un préstamo de 1.300 libras que aportó el conde ${ }^{(67)}$.

Si la proximidad de la peste había puesto en marcha toda una serie de medidas precautorias, su presencia en la villa hace movilizar los recursos humanos y materiales disponibles con el fin de paliar sus efectos.

La primera medida consistió en habilitar un lugar para los apestados, donde pudieran ser atendidos y aislados. En un principio se asignó la casa de Miguel Vaello en el Pla de la Font, extramuros de la villa. Debió ser insuficiente cuando el contagio alcanzó su máxima extensión. Se tiene igualmente noticia de la utili- 
zación, en el mismo lugar, de la casa de la viuda de Luis Jordá(68). Además, están los locales destinados para convalecientes ubicados en la almazara del mismo Pla de la Font ${ }^{(69)}$, en la ermita de San Cristóbal y en otros lugares(70).

Para dotar de operatividad a estos centros hacía falta personal, alimentos y medicinas; necesidades a las que debían sumar las del resto de los vecinos. Con la huida de la población se produce también la de los arrendatarios de los abastos municipales y tan sólo uno de ellos «procurava en algunes ocasions portar vastiments y favoria així a los de fora com als que restaven en la present vila en lo que

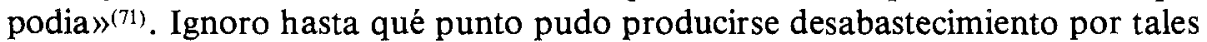
huidas y por la interrupción de las comunicaciones, aunque es de resaltar que, al menos en parte, funcionó la solidaridad entre localidades vecinas: los de Muro, pese a los pleitos que arrastraban desde hacía más de tres cuartos de siglo, socorrieron generosamente a los vecinos de Cocentaina con cargas de la apreciada nieve ${ }^{(72)}$.

El aprovechamiento de medicinas corrió a cargo de Miguel Espinós, apotecari, y es una de las partidas que después de la epidemia aparece como más gravosa: 1.200 libras reclama «per lo gasto que han fet en la cassa blanca, cassa de convalexients, hermites y altres llochs de la present vila y terme de aquella en les enfermetats del contagi y cuarentenes per lo sustento y medicines $)^{(73)}$. Cantidad cuyo cobro se alargará durante años, pese a todas las instancias del interesado.

Pero en ocasiones como ésta puede ser aún más difícil encontrar quiénes arrostrasen la enfermedad. La dirección la asumen los oficiales de la villa junto a los cuatro electos nombrados por el conde. Para el cuidado de los enfermos es contratado como médico a Francisco Pelecha, con una remuneración importante ${ }^{(74)}$. En su cometido será auxiliado por los frailes legos, mientras clérigos franciscanos ayudan a los de las parroquias de la villa a administrar los sacramentos ${ }^{(75)}$; hay también referencias, que sin duda están por debajo de la realidad, a la contratación de enterradores ${ }^{(76)}$. La necesidad hace recurrir a medios poco ortodoxos: Bartolomé Martínez, labrador, «pres y detengut en les presons», el 27 de julio, al comparecer ante el alguacil del procurador general, «promet y prometent se obliga per la ocurrència del temps que servirà en la casa hospital dita blanca per temps de tres mesos als malalts, y servirà en ella en toto lo que serà menester, axí sia cas enterrar los morts, si acàs hi agué, y cremar la robay; en caso de incumplimiento incurriría en la pena de 50 libras, cuyo pago aseguraba con cuatro fianzas ${ }^{(77)}$.

Medidas similares serán tomadas por las autoridades locales de Muro cuando el contagio prenda entre sus vecinos. Momblanch cita la contratación del mismo médico que atendía a los enfermos de Cocentaina, un cirujano, enterradores, formación de una morbería y designación de un lugar aislado para cumplir las cuarentenas ${ }^{(78)}$. Pero ninguna noticia me ha llegado de las tomadas en las otras localidades del condado, lugares con una administración municipal muy poco desarrollada, con recursos económicos limitados y de percepción extraordinaria - un reparto vecinal, fundamentalmente-, que generan un volumen de documentación insignificante y que sólo ha llegado hasta nosotros de forma excepcional.

El cotidiano discurrir de la vida queda interrumpido en el condado durante 
la epidemia y, según se recupera la salud, se intenta la vuelta a la normalidad. Las autoridades de Cocentaina hacen un balance de la situación y buscan soluciones a los problemas derivados de la reciente convulsión: saldan deudas, regularizan el cobro de las sisas ${ }^{(79)}$ y mandan purificar la ermita de San Cristóbal «ab fums de romer y espígol» junto con un blanqueo de cal(80).

Pero, desde nuestra experiencia cotidiana, lo más difícil es llegar a comprender el significado que tuvo la peste para quienes sobrevivieron. Asimilar el impacto que pudo dejar en la sicología individual y colectiva el terror sufrido ante el acoso de la muerte. Un testimonio de ese impacto nos lo afrece la documentación municipal, y puede servir de colofón a un apartado dedicado a las actitudes de la sociedad ante la peste.

Declarada la salud en la villa a principios de diciembre -que resultó provisional, como hemos visto-, los contestanos se ven sorprendidos por un hecho insólito, a todas luces escandaloso para sus conciencias. El seis de diciembre, las autoridades, en pleno, y muchos particulares acuden al Pla de la Font al tener conocimiento de unas noticias que han debido correr como la pólvora. Levantada acta de lo sucedido, con objeto de iniciar las acciones legales pertinentes, el mismo día es dictada sentencia. El mejor relato de lo sucedido nos lo da el bandeig pregonando en la plaza de la Cort:

«Atés y considerat que per lo acte rebut en lo dia de huy consta Balero Trensano, Lluís Botella y Juseph Palasí, fadrins de la present vila habitadors, huy de matí són estats dins de la cassa blanca que està en lo Pla de la Font sonant una guitarra y ballant hon se an mort molta gent -y entre aquells se an mort y estan soterrats en dit puesto pares, mares y germans de dits fadrins - lo qual han fet ab poch temor de Déu y desacato, y per lo perfil que pot haver exint de dita cassa inficionada de dit mal comunicant $a b$ algunes persones es pot tornar a pegar lo mal, del qual per ara per la gràcia de Nostre senyor Déu Jesuchrist està lliure la present vila».

Los irreverentes jóvenes no pueden ser apresados, pues huyen sierra arriba al ver el revuelo originado por su acción, pero ello no detiene a los miembros de la junta de la peste, quienes consideran debe procederse a un castigo ejemplar: de inmediato es publicado su destierro -durante determinado tiempo en concepto de cuarentena «y lo demés que sia convenient»-, pena de 50 libras si desobedecen y de 25 a quien los acoja ${ }^{(81)}$.

Huelga un mayor comentario, simplemente hacer notar cómo las circunstancias excepcionales que estuvieron en el origen de semejante conducta hicieron revocar pronto la pena de destierro, coincidiendo con la inmediata Navidad, «considerant que obeiren dit horde y cascú té nesesitat de donar rahó a ses cases y per la honra de les Santes Pasqües ${ }^{(82)}$.

\subsubsection{El impacto de la peste}

De todo lo dicho hasta aquí se puede colegir la importancia que la peste alcanzó en Cocentaina, aunque parece que la tuvo menor en los demás lugares del condado; el aprehenderla estadísticamente ya es más difícil: faltan las defuncio- 
nes en la parroquia de El Salvador, y en la de Santa María sólo se conserva el libro de albats, aunque podamos conocer el volumen de las defunciones de adultos a través de unos índices elaborados a principios del siglo XIX y los datos recogidos por Arques del Libro Racional de 1648, concordando ambas cifras; en la parroquia de Muro faltan totalmente los registros, y de las demás parroquias del condado sólo se conserva el de La Alcudia para tales fechas.

Son 111 adultos y 28 niños los que murieron de peste en la parroquia de Santa María en 1648, de un total de 183 fallecidos en ese año - 133 adultos y 50 niños- ${ }^{(83)}$. Cifras que suponen una mortalidad total en torno al $153 \%$ y del $116 \%$ directamente atribuible a la peste ${ }^{(84)}$. Con mucho, es la punta de mortalidad más señalada de la centuria (vid. gráfico 1), multiplicándose por cinco el número habitual de las defunciones; y aún cabría notar la falta de los posibles fallecidos de peste en el primer mes de $1649^{(85)}$.

Sin embargo, como sucede a menudo, estamos lejos de poder conocer la significación de tales cifras, pues debemos preguntarnos a qué población corresponde ese número de fallecidos y la calidad del registro en los momentos cumbres de la epidemia. Recordar que muchos habian huido de Cocentaina al declararse la peste, por lo que las tasas de mortalidad serían mayores en la medida que el divisor se redujese; y también en el mismo sentido, ocultando la verdadera incidencia de la epidemia, opera la posibilidad de que se realizasen entierros al margen de todo control, clandestinos o efectuados en el campo ${ }^{(86)}$. Pero es que, además, esos 139 muertos por la peste no deben ser todos parroquianos de Santa María. Dentro del territorio de la parroquia matriz recae el Pla de la Font, razón por la que todos los que murieron en la "casa blanca» debieron anotarse en sus registros. Así, resulta que esas defunciones de apestados deben incluir un número indeterminado de parroquianos de El Salvador y, quizá, de La Alcudia.

Ante semejantes dificultades, es mejor recurrir a una vía indirecta que puede servir para dar una idea del alcance de la tragedia, abriendo el campo de observación al conjunto del condado. El impacto de la peste, las pérdidas demográficas que originase, deben encontrar su reflejo en el número medio de bautismos (cuadro 1).

\section{CUADRO 1.-INCIDENCIA DE LA PESTE}

Medias de bautismo

Cifras absolutas Números índices

1645-1647 $1650-1652 \quad 1645-1647 \quad 1650-1652$

El Salvador

\begin{tabular}{clr}
$\begin{array}{ccc}24,3 \\
50,7\end{array}$ & & 23,3 \\
\cline { 1 - 1 } 75 & & 41,3 \\
& & 64,7 \\
5,7 & & 8,3 \\
3 & & 3,3 \\
9 & & 8,3 \\
\cline { 1 - 1 } 17,3 & & 20
\end{tabular}

100
95,9

Santa María

Cocentaina

a...

Alcocer ............................

Alcudia

Gayanes

Tres Parroquias

17,3

20

$\frac{100}{100}$
81,5 86,3 
Como he apuntado faltan los datos de la parroquia de Muro, que Momblanch ya no pudo consultar, aunque sabemos por este autor que, tras el paso de la epidemia, las actas del consell habian de muchas casas vacías por su causa ${ }^{(87)}$. Sin embargo, debemos tomar con precaución semejante referencia: la peste en Muro se declaró en fechas tardías, tuvo una duración más reducida que en Cocentaina, y las visitas pastorales no permiten hablar de una quiebra importante en la evolución de la población (gráfico 5).

En las parroquias pequeñas he preferido presentar un índice conjunto por su reducida entidad. En ellas, el paso de la epidemia no ha causado aparentemente una pérdida sensible de su población, aunque en La Alcudia se anoten algunos difuntos de peste ${ }^{(88)}$; al contrario, el número medio de bautismos registra un aumento tras la peste.

$\mathrm{La}$ incidencia negativa más visible se encuentra en Cocentaina, y, especialmente, en la parroquia de Santa María. En el total de la villa, hasta un $14 \%$ de la población puede haber desaparecido a causa de la peste. En abril de 1650, al repartir los gastos ocasionados por unos soldados, como se impone una cantidad fija por casa, se plantea la posibilidad de que no sea suficiente lo recaudado «que

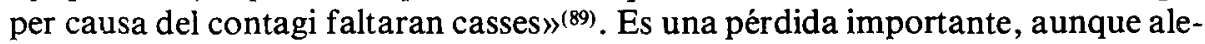
jada de las registradas en Orihuela y Valencia ${ }^{(90)}$, y en la línea de la incidencia general en el reino, que Casey estima entre la séptima y la octava parte de la población ${ }^{(91)}$.

Otra cuestión es la de las consecuencias a medio y largo plazo. Los registros parroquiales nos hablan de que no es posible hacer visiones apocalípticas. A falta de una estimación mejor sobre Muro, nos debemos ceñir a Cocentaina, pues en las demás parroquias, más fáciles de aislar por su escasa entidad poblacional y mayor autarquía, hemos visto su escasa repercusión.

Siguiendo las medias de bautismos (gráfico 4), en la villa condal se diferencian los comportamientos de sus dos parroquias: en la de Santa María, la peste parece abortar una tímida recuperación apenas iniciada una década antes, el número medio de los bautizados seguirá durante un cuarto de siglo oscilando sin una dirección definida; en la parroquia de El Salvador, en cambio, la peste de 1648 parece la señal de partida del aumento de población que preludiará el del XVIII. Además de su mayor o menor impacto, debemos tener en cuenta los propios mecanismos de recuperación demográfica de la sociedad. Es difícil decir si con la peste se ha producido una mortalidad selectiva y si tras ella, desaparecidos los más débiles, el número de defunciones es menor ${ }^{(92)}$; pero es evidente la reacción en el número de matrimonios (gráfico 1) que tienden a recomponer parte de las familias disociadas por la peste y a sustituir a las que faltaron.

En otro orden de cosas, la peste dejará el legado de unas deudas muy gravosas. A partir de noticias dispersas he sumado hasta mil libras por gastos diversos, una cifra que sin duda está por debajo de la realidad ${ }^{(93)}$. Para la economía municipal de Cocentaina es una cantidad importante, aún más que por la cifra en sí por lo caótico de sus finanzas; y a ella cabría añadir las cantidades condonadas a los arrendatarios de las sisas ${ }^{(94)}$. A la desgracia habían intentado sacarle rendimiento, y, desde los momentos de las primeras precauciones, fue arrendado el derecho de expedir y refrendar las patentes de sanidad por 8 sueldos diarios ${ }^{(95)}$, 
pero no es de suponer que su rendimiento compensase las pérdidas sufridas por los distintos conceptos.

Una vez desaparecida la epidemia, la hacienda municipal procura resarcirse de algunos gastos. Así, intentan cobrar la sisa de las transacciones realizadas en tiempo de peste ${ }^{(96)}$; acuerdan que aquellos que estuvieran en la «casa blanca» y lugares de convalecencia, o sus herederos, paguen en la medida de sus posibilidades los gastos ocasionados, en principio asumidos por la villa ${ }^{(97)}$. De todas formas, me atrevo a calificar de mayor la incidencia de la peste en el terreno económico - refiriéndome a las finanzas municipales- que en el demográfico. Buena prueba de ello es el tiempo que se arrastrará la deuda de 1.300 libras contraída con el conde por razón de la epidemia ${ }^{(98)}$.

\subsubsection{De nuevo el miedo}

A partir de enero de 1649 , el temor a que volviese la peste a Cocentaina sigue presente en algunas determinaciones concejiles, aunque las referencias más numerosas aluden a los problemas legados por la epidemia de 1648 . Del escueto mapa trazado por Nadal resulta que, en los años inmediatos, la peste se aleja del reino de Valencia, dejando a su paso la habitual estela de muerte ${ }^{(99)}$. Pero el miedo cobra nueva fuerza con las alarmantes noticias llegadas a fines de junio 1652 de que la peste ha vuelto a hollar el solar valenciano.

Del nuevo brote existen contadas referencias en los trabajos de historia de la población valenciana. Los estudios más conocidos sobre las epidemias de mediados de XVII, como son los relativos a Valencia y Orihuela, limitan su atención a los años 1647-1648, y en otros de carácter local apenas cabía encontrar alguna mención ${ }^{(100)}$, sin aportar mayores precisiones, hasta que la reciente monografia de Santiago La Parra ha analizado con detenimiento la incidencia de la peste en 1652 en Gandía, una de las poblaciones donde se cebó con especial virulencia ${ }^{(101)}$.

Todavía no es posible determinar el origen del contagio en este segundo brote, ni siquiera saber si la peste mantuvo en el reino una existencia atenuada desde 1649 , aunque esto parece poco probable ${ }^{(102)}$. En Gandía se habla de que la peste llegó por mar desde Nápoles a mediados de junio, pero produce una cierta indeterminación el hecho de que viniese precedida por una «fiebre modorra» contagiosa y que encontremos en las actas de sepultura indicaciones como «ia comensa a córrer lo principi de la pesta» ( 7 de febrero) o «comensa la peste per pulgó y tavardillos» (24 de marzo) $)^{(102 b i s)}$.

De todas formas, apuntar que el origen napolitano está fuera de lugar, pues la peste no hizo acto de presencia en esas tierras hasta 1656. Quizá la mencionada barca contrajese la epidemia al recalar en Mallorca, que estaba infectada en $1652^{(103)}$; y ello explicaría también el brote más septentrional de Castellón, que no parece estar en relación con los focos aragoneses, porque en dicho año la peste en Aragón se había retirado al N. del Ebro, lejos de la frontera valenciana ${ }^{(104)}$.

Los primeros informes concretos los transmiten los jurados de Alcoy por carta de 29 de junio de 1652 . Los puntos infectos todavía están lejos; citan sólo a Castellón de la Plana, localidad donde "y a mal contagiós» y de la cual se guardan, habiendo obligado a cumplir cuarentena a dos frailes que venían desde allí(105). 
Pocos días después son registradas las declaraciones de distintos testigos. Las prestadas el dos de julio hablan de las medidas precautorias - cierre de portales y vigilancia permanente - tomadas en Alcoy ${ }^{(106)}$. Al día siguiente, es ampliada con otros viajeros la relación de las localidades sospechosas de estar apestadas: «Benimelis, Sanet, Noguerals, Beniarbeix, Verger, Ondara, Pedreguer y Gata ${ }^{(107)}$. Ante tales noticias, es convocado el día cuatro un consell particular «per a fi y efecte de custodiar y guardar la present vila de perçones y robes de parts infectes y morboses». Su decisión es inmediata: dejar sólo dos portales hábiles al tránsito y colocar en ellos guardias ${ }^{(108)}$.

La peste va ganando terreno. No sé si es por comisión del concejo, pero vemos al doctor Pelecha, que ya cargó con el cuidado de los apestados en 1648, remitir información precisa sobre los avances de la enfermedad y su proximidad en una carta que es interesante recoger:

«Señor justicia y jurados.

Oy sábado a 27 del corriente an benido de Gandía un hombre y muger a esta villa de Pego, y les an echo salir en pena de la vida. El hombre a dicho delante de jurados y muchas personas que en Gandía hay casa blanca y que mueren mucho. El señor duque se sale oy de Gandía, y esto es cosa cierta. Dicho hombre ha dicho delante de mí que los vicarios de Gandía desen a voz pública que no se podía encubrir el mal tanto tiempo porque sería causa de mucho danyo y assí ya se publica por ellos mesmos. En Rafelcosser, cerca de Gandía, ay contagio, que una muger que llevó pollos le ha traído. Lo que conbiene es guardarse. El poco papel es causa de escrivir a V. Ms. tan corto, lo demás a la vista. A quien me guarde el cielo los años de mi dezeo. Y Pego, a 27 de julio de 1652.

Lo doctor Francisco Pelecha» ${ }^{(109)}$.

Volvemos a encontrar en esta relación comportamientos ante la peste documentados repetidas veces: la resistencia a declararla por parte de las autoridades municipales, la huida de los notables, la evidencia empírica de tratarse de una enfermedad contagiosa que puede ser introducida por cualquier persona procedente de un lugar apestado.

Las noticias del foco de Gandía debían ser nuevas, pues los munícipes se apresuran a comunicarlas a sus vecinos de Alcoy. Un día después de haber salido la carta de Pego, ya reciben en Cocentaina las expresiones del más rendido agradecimiento y la promesa de corresponder a sus desvelos: Alcoy también corta su comunicación con las localidades ahora afectadas ${ }^{(10)}$.

Conforme se aproxima la peste, la vigilancia es más rigurosa. El justicia y jurados de Planes piden información sobre la causa del fallecimiento en Benifallím de un hombre procedente de Gandía, el cual también había sido visitado por el doctor Pelecha(1i1). Pero no hay noticia de mayores progresos de la epidemia más allá de algún foco aislado en el valle de Gallinera.

Dos desplazamientos del mencionado Pelecha suscitan reservas entre los contestanos, ante el temor de que pueda ser el introductor de la epidemia en la villa. Parece que el médico había hecho valer su experiencia acumulada en situaciones similares, y entró en contacto con las autoridades de Gandía «per a anar a vi- 
sitar (...) los malalts ferits del contagi» ${ }^{(112)}$. Por ello, el justicia y los jurados prohíben al padre recibirlo en su propia casa sin un previo examen de los certificados que aporte de su salud. Cuando llegue el momento de hacerlo, una simple duda sobre el sello del bol-latí traído por el doctor será razón suficiente para enviar un emisario hasta Gallinera ${ }^{(113)}$.

La carta de los oficiales de este valle, certificando que el doctor Pelecha no ha tenido contacto con ningún apestado, nos proporciona las referencias ciertas sobre el punto de mayor proximidad de la peste en este segundo embate, al tiempo que un relato del drama que el contagio podía suponer para los afectados:

(...) en dita vall no i a malalt nigú, si no és un poblet de dos cassas que-s diu Llombay [en el cual] passant dit doctor i fent son camí en companya de Nicolau Seguí, los fills y muller del home que morí en dies passats, com fan corantena, cridaron-lo que li volien parlar. Y dit doctor anà i de obre de 60 pasas digué què $i$ a de nou. Digué lo fadrí que-stava mal. Diu lo doctor aont vos fa mal. Diu a tal i a tal part. Y lo doctor dius totom sa guarda que's contagi. Y la muller digue-li: senyor no'm dirà ninguna cossa. I el doctor, ia com se'n anava, no's girà sinò que digué: ya u diré. Y luego se'n anàs i donà orda que avisasen tota la vall que's gordasen de dit poblet $(\ldots)^{(114)}$.

A pesar de su experiencia en el trato con los apestados, quizá por ella, el doctor Pelecha no se aproxima al paciente sospechoso de portar el mal. Desde una prudente distancia emite su particular telediagnóstico, el cual interesa más a quienes todavía gozan de salud que a los atacados por la epidemia, pues para éstos es casi una sentencia de muerte.

Las precauciones tomadas ante el nuevo brote de la epidemia parece que surtieron efecto y los focos litorales quedaron aislados, sin extenderse el contagio a las villas del interior; no obstante, la situación de alerta permaneció vigente durante el resto del verano. En Muro acordarán cerrar los portales en una fecha tan tardía como es el 25 de agosto, y -aunque la última mención expresa a la peste en los libros de consells de Cocentaina es del 17 de agosto - todavía una junta del 1 de septiembre discute si dejarían entrar en la villa a una mujer enferma «de fret y febra» en una casa de campo: por mayoría, previa relación del doctor «de que no és mal que es pot pegar ni contagiós» atienden su demanda ${ }^{(115)}$. Pero pronto, a mediados de septiembre de 1652 , el foco pròximo de Gandía recobra la salud ${ }^{(116)}$ y no parece que hubiese nuevos brotes en los años inmediatos.

\subsubsection{Ecos de la última peste de la España moderna}

Durante casi un cuarto de siglo el temor a la peste no encuentra reflejo en la documentación consultada. Los problemas vuelven a ser los cotidianos, y en Cocentaina el paso de la epidemia sólo será recordada a través del empréstito concedido por la condesa para hacerle frente; cuya cuantía no hace sino agravar, aún más si cabe, la bancarrota de las finanzas municipales.

Pero en 1676 vuelven a aparecer en las deliberaciones del consell noticias referentes a la que será la última epidemia de peste que asole el territorio español ${ }^{(117)}$. 
Los primeros datos proceden de Alcoy, de donde comunican el 25 de junio de $1676^{(118)}$ que Alicante ya ha cortado su comunicación con Cartagena, puerto difusor del nuevo brote. La junta particular -órgano ordinario de la administración municipal- decidirá de inmediato concentrar el tráfico de la villa por dos puertas, poner en ellas guardas y dar amplios poderes a los oficiales de Cocentaina ${ }^{(119)}$.

En línea con las precauciones habitualmente tomadas, la junta particular acuerda, cinco dias más tarde, tapiar los huecos de las murallas y cerrar los portales secundarios, procediéndose al nombramiento de seis electos que auxilien a las autoridades en estos momentos ${ }^{(120)}$. Pero la amenaza del contagio no debía sentirse muy próxima cuando, a fines de septiembre, la junta aprobaba - aunque por un escaso margen de 16 contra 13 votos-mantener la convocatoria de la feria de octubre con el concurso de gente de las más diversas procedencias ${ }^{(121)}$. De hecho, este primer embate tuvo escasa incidencia incluso en su centro de difusión ${ }^{(122)}$.

La preocupación por la peste mengua con el invierno, para renacer a la llegada del calor. El dos de mayo de 1677, ante las noticias de estar infecta Murcia, son tomadas medidas similares a las del año anterior, intentando ejercer un mejor control en el despacho de las patentes de sanidad ${ }^{(123)}$. La peste invade las tierras bajas productoras de seda y donde la siega se adelanta respecto a las sierras del interior; esta diferente estacionalidad de los trabajos agrícolas hace que muchos braceros acudan a Murcia y a la Vega Baja en busca de un jornal, temiéndose que su regreso suponga el franqueo por la epidemia del cordón sanitario formado en torno a Orihuela y Alicante ${ }^{(124)}$. Por ello, las órdenes remitidas desde Valencia son estrictas: debe extremarse la vigilancia sobre estos emigrantes estacionales $^{(125)}$.

Y es una preocupación que crece, pues la peste está ya en Elche, Sax y Jumilla a principios de junio ${ }^{(126)}$. Ante esta situación, el día siete del mismo mes es publicada una crida sobre las notícies del contagi(127). Con ella, el justicia y los jurados prohíben recibir forasteros y comprar mercancías extrañas, en especial telas, si no es con su previo examen; y extreman además las comprobaciones sobre la validez de las patentes de sanidad presentadas por los recién llegados a la villa. Las penas impuestas a los contraventores constituyen el más claro reflejo del temor ante la epidemia: cinco años de galeras, confiscación de bienes y otras arbitrarias a criterio del justicia.

Dos días después queda completada la normativa con unas Ordenances que es feren sobre el guardar en lo contaxi de Múrcia y Cartaxena ${ }^{(128)}$ dictadas por la junta de electos, las cuales intentan conseguir un control más efectivo del tráfico de hombres y mercancías.

De nuevo la llegada del invierno apaga los ecos de la peste. Será el 29 de marzo de 1678 cuando renazca la preocupación: el síndico comunica al consell «que les notícies que huí de present se tenen en la present vila del contagi que diguen y a en la ciutat de Oriola són molt males, que es diu clarament que és contaxi»(129). La alarma está justificada, pues si la peste se enseñorea ya de Orihuela significa que ha roto el cordón sanitario establecido dos años atrás. Así, por tercer año consecutivo, en Cocentaina establecen el control de las puertas de la villa, nom- 
bran una junta de seis electos y toman las demás precauciones habituales ${ }^{(130)}$.

Pero el cordón sanitario, en el que tantas esperanzas tenían depositadas las autoridades valencianas, resistió, logrando ser aislado el foco de Orihuela y quedando a salvo el resto del Reino. Precisamente la última mención a la peste en la Cocentaina del Seiscientos será una carta de 10 de agosto de $1678^{(131)}$, remitida por los estaments de Valencia, reclamando las 37 libras y 2 sueldos que le habían correspondido a la villa en el reparto del coste de las medidas profilácticas. El nuevo brote de 1678-1682 dirigirá sus pasos de muerte hacia Andalucía y ya no preocupará más al consell contestano.

\section{OTRAS CRISIS DE MORTALIDAD}

La peste ocupa en primer lugar como origen de las crisis de mortalidad del Seiscientos, al menos por la atención que ha suscitado. En el condado de Cocentaina hemos visto que causa la punta de mortalidad más prominente de la centuria, pero es obvio que no es la única causa de sobremortalidad que incidió sobre la sociedad de la época. Además de la peste se encuentran presentes las «pestilencias», concepto más amplio que incluye factores epidémicos de diverso tipo ${ }^{(132)}, \mathrm{y}$ también hemos visto en los arrendamientos de sisas, de derechos dominicales, de diezmos, en los libros de consells, cómo el abanico de los miedos sentidos por los hombres de otrora se abría a las inclemencias climatológicas - cuya incidencia en los cultivos podía acarrear el hambre - y a la guerra.

Los gráficos 1-3 identifican los momentos en los cuales un fuerte incremento en el número de los difuntos pone en peligro el positivo desarrollo de la población. Hablar de años o períodos de crisis plantea algunos problemas. El primero, es la desigual cobertura de las series, circunstancia que impide, las más de las veces, saber la extensión de determinada sobremortalidad. Esto, junto al carácter localizado del presente trabajo, aconseja ser cauto a la hora de identificar una crisis, puesto que algunas pueden ser puntas locales, atribuibles a circunstancias muy particulares, y, en algunos casos, a la misma reducida entidad de las poblaciones en estudio, originadas entonces por oscilaciones puramente aleatorias de los datos.

En una visión de conjunto, cabe hablar de la poca incidencia de las crisis de mortalidad: 72 años cubren las series de Santa María entre 1610 y 1709, en 16 de ellos la mortalidad superaría el $40 \%$ y sólo en 9 el 50\%, los 17 años de saldos negativos acumulan un pasivo de 404 individuos, 153 de los cuales corresponden a la peste de 1648; en El Salvador, durante 64 años, cabe anotar en 7 ocasiones mortalidades superiores al $40 \%$, de ellas 4 por encima del $50 \%$, los 10 saldos negativos suman únicamente 76 personas - faltan los datos de las mayores crisis- en una parroquia de unos 650 habitantes a mediados de siglo; en La Alcudia registramos 11 años de mortalidad superior al $40 \%$ entre los 70 de los que poseemos datos, siendo en la parroquia de menor vecindario donde hay puntas de mortalidad más señaladas; por último, las series conjuntas de Alcocer y Gayanes, en 26 años, sólo registran en una ocasión una mortalidad superior al 50\%, y en otra está entre el 40 y el $50 \% 0^{(133)}$.

Hemos mencionado las mortalidades calculadas a partir de los datos por año 
civil; pero tampoco, si nos atenemos a los de por años-cosecha, observamos que la fisonomía general de las crisis sufra una modificación sensible, aunque puntualmente alguna pueda quedar diluicha o aparecer otras que antes quedaban enmascaradas ${ }^{(134)}$.

Vemos que sólo son dos los períodos de gran mortalidad que se perfilan con claridad: la peste de 1648, con mucha diferencia, y la primera década del Seiscientos, en especial el año 1707. Habiéndonos referido ya a la peste, conviene detenerse en esa segunda crisis de mortalidad situada a caballo entre dos siglos y en una coyuntura especialmente adversa: La Guerra de Sucesión.

\subsection{7-1708: Guerra y muerte}

La crisis de 1707-1708 viene precedida por una serie de años difíciles, iniciados al poco de doblar la centuria. Los datos por año civil nos hablan de una punta de mortalidad en 1703, cuando el número de óbitos duplica la media del quinquenio anterior, y otra menos señalada en 1706; si acudimos a los datos por añocosecha, vemos aparecer un primer saldo negativo en el de 1701-1702, mientras que la crisis atribuible a la Guerra de Sucesión adquiere un nuevo perfil, al extenderse a los años agrícolas de 1706-1707 y 1707-1708. E interesa hacer un breve análisis comparativo de estos años críticos, por las diferencias en su fisonomía.

En 1701 estamos ante una sobremortalidad que cabalga sobre dos años civiles, y desaparece si tomamos este marco de estudio (gráfico 6). En la parroquia de Santa María, el número de las defunciones empieza a ser más elevado que lo habitual durante el verano, y mantiene esta tónica hasta el primer trimestre de 1702. El aumento de óbitos no es muy señalado, y afecta tanto a las series de adultos como a las de niños; coincidiendo, además, con un descenso notable (c. $70 \%$ ) en el número de concepciones, pero sólo en los tres primeros meses de 1702: podríamos pensar que nos encontramos ante una crisis de subsistencias poco pronunciada, por lo que no incidiría en el número de matrimonios. Pero esta «crisis larvada» no encuentra un especial reflejo en el resto de las parroquias del condado, aunque en la de El Salvador hay un ligero incremento de la defunciones de albats en la primera mitad de 1702 .

En 1703 el aumento de óbitos se debe exclusivamente a una multiplicación de las defunciones de albats. En la parroquia de Santa Maria, si en la década de 1690-1699 los niños suponen el 48\% de las defunciones, en el año que comentamos son el $76 \%$; si los sepelios de cosos aumentan en un $54 \%$ respecto a la media quinquenal, los albats lo hacen en un $246 \%$. Aunque no disponemos de defunciones de adultos en la parroquia de El Salvador, los albats registran un aumento porcentual similar al de Santa María. En ambos casos, las defunciones se concentran en un corto período de tiempo: entre septiembre y noviembre fallecen el $83 \%$ de los albats de ese año en la parroquia matriz y el $73 \%$ en la del arrabal.

La crisis de 1707 tiene una fisonomía diametralmente opuesta. Las defunciones de albats no registran variación significativa en ninguna de las parroquias de la villa, ni tampoco en las de Alcocer y Gayanes ${ }^{(135)}$ : se explica la sobremortalidad por los fuertes aumentos de las defunciones de adultos.

La distribución estacional de los óbitos también difiere sensiblemente de la 
observada en 1703. No están concentrados a fines de verano y principios de otoño, pero tampoco es del todo paralela en las parroquias que conservan el registro. En Alcocer, aumentan los óbitos en diciembre de 1706 y perduran las malas condiciones durante todo el siguiente año; en Gayanes, la crisis está más concentrada entre enero y julio de 1707 , aunque en ambos casos la reducida entidad poblacional de las parroquias provoque una cierta indeterminación. En Cocentaina, según los registros de Santa María, tiene un inicio más temprano y una duración más prolongada: desde agosto de 1706 a julio de 1708 . Pero en los tres primeros meses - de agosto a octubre de 1706 - se trata de una sobremortalidad de albats de desarrollo estivo-otonal, y será sólo a partir de noviembre cuando se inicie un aumento de defunciones de adultos, que durará hasta mayo de 1708 , pues en julio de este año también nos encontramos con una preponderencia de difuntos menores de 7 años. Vemos que en 1707 no estamos ante una de esas típicas sobremortalidades mediterráneas de desarrollo estival, debidas a las enfermedades gastrointestinales y con una fuerte incidencia entre los niños.

Entonces, debemos preguntarnos las causas de la crisis. Estamos en los momentos más duros de la guerra, y Cocentaina sufre las alternativas de la lucha con los sitios de Alcoy hasta su toma el 8 de enero de $1708^{(136)}$. Sin embargo, no aparece en los libros de sepulturas el reflejo de una especial mortalidad por acciones bélicas. Figuran ejemplos aislados, como ese setabense que «murió de las heridas que tenía del sitio de Xátiva»(137), y también varios soldados; pero en modo alguno son suficientes para explicar el incremento de las defunciones.

Los registros parroquiales no ofrecen más elementos de juicio para identificar las causas de la crisis, pero otras fuentes han aportado noticias más explícitas. Pérez Aparicio cita la preocupación existente en Valencia a principios de 1707 por las enfermedades declaradas en Agres, Alfafara,Bocairente, Cocentaina, Onteniente y lugares comarcanos; en febrero de 1707 pagan al doctor Juan Bautista Caudí 20 días de dietas por visitar las localidades afectadas, y en Valencia celebran consultas distintos médicos para analizar el mal(138).

Conocemos el paso del doctor valenciano por Alcoy, la epidemia en esta villa, la contratación de médicos para atender a los muchos enfermos y la constitución de una casa de convalecientes ${ }^{(339)}$. En Cocentaina, la visita de Juan Bautista Caudí da lugar al levantamiento de dos actas notariales que constituyen la fuente más directa para estudiar la epidemia de 1707 , junto a noticias procedentes de un libro de órdenes de pago de los jurados.

El 15 de febrero llega a Cocentaina el citado doctor Caudí, médico ordinario de Valencia, comisionado por la ciudad upara examinar y ver la calidad de la epidemia y enfermedad que al presente padecen los vecinos y moradores de dicha vi-

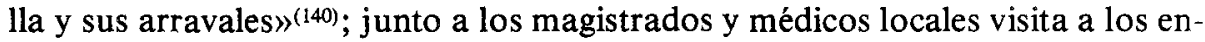
fermos, que están

«(...) padeciendo una calentura podrecida de género ardiente maligna, en unos propria por quitarle luego las fuersas en otros impropria por los muchos accidentes que la acompañan, como son delirios, sopores, puntículas, movimientos convulsivos y en otros gangrenas etc.».

Son 107 los enfermos visitados, tanto en sus casas como en el «hospital de 
portugueses»; pregunta a los médicos que los atienden «si avían adnotado en dicha constitución de enfermedad algunas pústulas malignas de las que acompañan a las enfermedades pernisiosas y pestilentes», y la respuesta es negativa. El comisionado valenciano dicta entonces algunas medidas y delega su autoridad en el doctor José Pujasons: todos los enfermos pobres que no tengan lo necesario para su sustento deberán ser recogidos en una «enfermería» para alimentarlos con más facilidad; a los que hayan superado la enfermedad les será señalado un lugar de convalecencia "para que no comuniquen con nadie, pues el tiempo de la convalecencia se apega con mucha facilidad a los cincunstantes"); aprueba la disposición del «hospital de los portugueses», ubicado en el palacio del conde, «sólo resta se riegue con agua y vinagre y se queme enebro y romero, para que esté purificado y los asistentes no reciban daño».

El doctor Caudí vuelve a visitar Cocentaina el 30 de marzo del mismo año (141), ahora de orden de la ciudad de Valencia y del virrey. Encuentra en cama 27 enfermos «de los naturales» y 35 «en la enfermería de los portugueses», con análogo diagnóstico al emitido el mes anterior, y completa las disposiciones entonces dictadas:

«(...) tengan obligación de asistir a los pobres enfermos con aquello que se requiere para la verdadera curación, y luego que se vaian los soldados portugueses se mande limpiar todas las casas, sacando el estiércol ý cualquier inmundicia que huviere en dichas casas y después aserlas purificar quemando huna poca pólvora y después enebro y romero, y más en donde aya avido enfermos, y después mandar limpiar todas las calles, mandando aser a los vesinos de dicha villa cada uno su frontera, en pena de tres libras (...) Que luego que se vaian los soldados, la enfermería del palacio se purifique en la mesma forma, y la ropa que aya servido en dichos enfermos las mande quemar para que de este modo quede con toda seguridad esta villa; y la que haya servido en los naturales se lave y purifique (...)».

Semejantes disposiciones parecen apuntar a que se vislumbra el fin de la epidemia; sin embargo, los libros parroquiales continúan registrando un número de defunciones superior al habitual hasta mayo del año siguiente, y los libramientos de pago indican que siguen vigentes medidas excepcionales: el 2 de diciembre se satisfacen a Basilia Ferrando 20 sueldos por otros tantos días que han servido a los enfermos del hospital «per no haver hospitaler»; el mismo día, 61 sueldos a los jurados «que se'n an gastat en los malalts del hospital, per no bastar el socorro que els donaven, y dits jurats cuidar de dits malalts per no haver-i mayordom en carn, sucre y ous»; el 26 del mismo mes, 12 sueldos por lavar la ropa de los enfermos del hospital y 9 sueldos a un jurado por ayuda de gasto(142).

La descripción de los síntomas hecha el 15 de febrero apunta a identificar a la epidemia como tifus exantemático(143), una epidemia que no se circunscribió a las localidades antes mencionadas sino que se extendió por un área mucho más amplia ${ }^{(144)}$. El tifus exantemático está en estrecha relación con las crisis alimenticias $^{(145)}$, lo que nos lleva a preguntarnos si existía hambre en Cocentaina en esos momentos.

Es difícil dar una respuesta correcta, puesto que la documentación munici- 
pal es deficiente, como un reflejo más de las alternativas de la guerra. Sabemos que en marzo de 1706 se está vendiendo el trigo a 120 sueldos el cahíz ${ }^{(146)}$, lo que es un precio bajo para los meses finales del año-cosecha; el 23 de mayo los contestanos remiten 20 cahíces de harina a Játiva y ponen a disposición de Baset los que sean menester ${ }^{(147)}$, hay reservas en la villa poco antes de la cosecha; pero no dispongo de otros datos hasta julio de 1709, cuando el cahíz alcanza los 180 sueldos ${ }^{(148)}$, el precio más alto registrado durante décadas no sólo en los meses de cosecha sino incluso en los de soldadura ${ }^{(149)}$. Ahora, carezco de datos locales para los años agricolas de 1706-7 y 1707-8: no sé si es posible hablar de escasez, de hambre, o sólo atribuir la mortalidad a las convulsiones de la guerra y, sobre todo, a la presencia de ese permanente foco infeccioso que constituyen los ejércitos de la época; es sintomática la fuerte incidencia entre los portugueses, soldados del bando austracista ${ }^{(150)}$.

Podríamos intentar el seguimiento de la presencia del hambre en una lectura del componente estacional de las series de matrimonios y, sobre todo, de concepciones (gráfico 7). Sin embargo, los datos no permiten extraer demasiadas conclusiones, pues existen sensibles divergencias entre las distintas series parroquiales. En parte es debido a factores aleatorios, por la reducida entidad de las poblaciones, pero no he querido intentar obviar este problema con la presentación de un gráfico conjunto, pues podía dar una idea de concordancia de comportamientos que dista de ser real.

En la parroquia de El Salvador, la baja pronunciada de las concepciones en el cuarto trimestre de 1706 y el primero de 1707 podía llevar a la conclusión de que nos encontramos ante la amenorrea producida por el hambre, y en el mismo sentido apunta la serie conjunta de Alcocer y Gayanes. En cambio, la serie de Santa María no corrobora semejante baja estacional. Dado que las concepciones desde octubre de 1706 a marzo de 1707 son estimadas a través de los nacimientos de la segunda mitad de 1707, hay que preguntarse si realmente hemos medido una baja de concepciones o la huida de población en el segundo semestre de 1707, cuando las actividades bélicas en la zona están en todo su apogeo; en la parroquia de Santa María de Cocentaina incidiría menos la presencia de los ejércitos en liza y sus saqueos por comprender la parte murada de la villa, donde incluso algunas familias de otras localidades buscarían refugio. En estas condiciones, la única conclusión posible es que las turbulencias de la guerra pueden imponerse a cualquier otra consideración en la configuración estacional de las series, con lo cual es arriesgado una interpretación.

Tampoco en las actas de matrimonio existe demasiada concordancia. Hay bajas en los momentos de la crisis, aunque no demasiado sañaladas. Sin embargo, sí que es significativa la reacción tras la crisis en la parroquia de Santa María, donde entre octubre de 1708 y junio de 1709 se celebran 26 matrimonios -frente a una media anual de 9 en el quinquenio anterior-, y algo menos importante es el incremento de celebraciones en las de Alcocer y Gayanes; por el contrario, en la parroquia del arrabal no aparece semejante movimiento compensatorio.

Hemos hablado de las turbulencias de la guerra como modificadoras del componente estacional de las concepciones aparentes, hay que preguntarse también hasta qué punto enturbian la correcta estimación de la incidencia de la mortalidad. 
En primer lugar, no podemos decir a qué volumen de población se refiere el número de defunciones registrado: los desplazamientos de personas fueron importantes a lo largo de 1707 y primera mitad de 1708 , siendo imposible hacer mayores precisiones; sólo por esta razón la tasa de mortalidad es falsa, sin que podamos decir en qué sentido.

Pero además, como sucede a menudo en las grandes mortalidades, existe la sospecha de una fuerte subestimación en el número de las defunciones. La primera visita del doctor Juan Bautista Caudi, el 15 de febrero de 1707, ofrece también una evaluación de víctimas: «aviendo visto y reconosido el libro racional, se han allado escrito ser muertos desde octubre próximo passado ciento y cinco entre

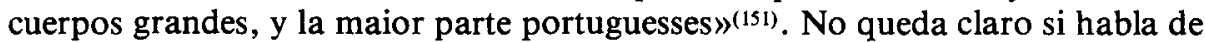
las dos parroquias, pero semejante cifra apunta a que los datos de los registros parroquiales utilizados subevalúan la incidencia de la epidemia: entre octubre de 1706 y febrero de 1707, inclusive, son anotadados 39 difuntos en la parroquia de Santa María, de los cuales 25 son adultos. La diferencia no puede atribuirse a la falta de los registros de El Salvador, especialmente cuando el hospital habilitado entonces -el alcázar condal- está dentro de los límites de la parroquia matriz. Quizá pueda explicarse la diferencia porque no fuesen inscritos en la parroquia los fallecidos en el hospital, mas cuando "siendo la maior parte portuguesses» - es decir, soldados del Pretendiente - acaso escapasen al control parroquial por estar bajo administración castrense. En tal caso, también estarían subevaluadas las muertes en acción bélica.

Ahora, debemos preguntarnos cuáles fueron las consecuencias de la crisis de 1707-1708 en la evolución a medio y largo término de la población del condado de Cocentaina. Sin duda, a la Guerra de Sucesión hay que atribuir esa notable muesca dibujada por el gráfico que representa la evolución de las medias de bautismos (gráfico 4). Una muesca que nos habla de una pérdida de población que trunca el crecimiento iniciado en la segunda mitad de la centuria anterior.

Volvemos a tropezar con la dificultad de la falta de cifras totales de población que enmarquen la crisis y permitan estimar su incidencia. Está el conocido vecindario de Campoflorido, y podríamos recurrir también a otros de carácter local. Pero, por un lado, carecemos de vecindarios para los primeros años del Setecientos y, además, los datos ofrecidos por el vecindario de Campoflorido son rechazados por su nula fiabilidad(152). Ante esta situación, podemos acudir de nuevo al cálculo del impacto de la crisis a través de las medias de bautismos, procedimiento utilizado ya al hablar de la peste de 1648 .

Estos datos nos vienen a dar una idea aproximada de la incidencia demográfica de la Guerra de Sucesión: no la tendría en Gayanes, pese a que la primera mitad del año 1707 registra una importante mortalidad; apenas supondría la pérdida de un $6 \%$ de la población de El Salvador, la parroquia que comprende el antiguo arrabal morisco de Cocentaina; pero, en cambio, las consecuencias son dramáticas en Alcocer y Santa María. Las cifras de las dos parroquias en último lugar citadas tienen una significación muy diferente: Alcocer es un pequeño lugar que parece haber llegado al techo de su expansión demográfica -en todo el XVIII el número medio de los bautismos no supera el nivel alcanzado en 


\section{CUADRO 2.-INCIDENCIA DE LA GUERRA DE SUCESION}

Medias de bautismos

Cifras absolutas

Números índices

1703-1705 1709-1711 1703-1705 1709-1711

El Salvador

\begin{tabular}{|c|c|c|c|}
\hline $\begin{array}{l}47,3 \\
72 \\
\end{array}$ & $\begin{array}{l}44,3 \\
48\end{array}$ & $\begin{array}{l}100 \\
100 \\
\end{array}$ & $\begin{array}{l}93,6 \\
66,6 \\
\end{array}$ \\
\hline 119,3 & 92,3 & 100 & 77,4 \\
\hline 12,3 & 5,7 & 100 & $\begin{array}{r}45,9 \\
\end{array}$ \\
\hline
\end{tabular}

Alcocer

14,7

15,3

104,1

1700-, pero la parroquia de Santa María es la más importante de Cocentaina, donde reside la oligarquía de la villa, e incide de tal manera en el conjunto de la localidad como para que pueda estimarse una pérdida total de casi la cuarta parte de la población.

El ejemplo de Cocentaina dista de ser excepcional, y por doquier, en las parroquias vecinas, la Guerra de Sucesión deja una huella más o menos señalada ${ }^{(153)}$. Pero esta disminución de los efectivos totales no puede ser explicada sólo por los saldos negativos acumulados en los años de crisis - aún cuando pensamos que subvalúan su importancia real- sino que debemos acudir para hacerlo a los movimientos migratorios, sin desechar otros posibles factores ${ }^{(154)}$.

Calcular la importancia de los movimientos migratorios -y más de la emigración - es siempre difícil. Noticias muy vagas hablan de los desplazamientos impuestos por las alternativas de los ejércitos en liza ${ }^{(155)}$, desconociendo su radio y duración. Pero el final de la guerra, por el especial carácter de enfrentamiento civil que tuvo en el reino, no supuso la vuelta inmediata de todos aquellos que se habían visto obligados a abandonar sus hogares, y otros, los del bando austracista, debieron tomar entonces el camino del exilio.

Los datos no son muy precisos: los registros de confiscaciones anotan 145 reos de ayudar al Pretendiente huidos de Cocentaina, algunos con sus familias. Muchos de ellos no van más allá de un provisional refugio en los últimos núcleos de resistencia antiborbónica, y vuelven a lo largo de 1708 aprovechando las garantías ofrecidas por sucesivos bandos publicados con este objeto; aún así, al menos 26 no regresaron y otros 3 pasaron a residir en Muro y Villena(156). Pero a partir de estos datos es difícil conocer el montante definitivo de la emigración.

La despoblación causada directa o indirectamente por la guerra, podía ser importante ${ }^{(157)}$, pero tanto o más podía serlo por la desarticulación económica inmediata: se conjugaron difíciles años en la agricultura, la presencia de importantes contingentes de tropas a las cuales había que mantener y, sobre todo, la introducción de los nuevos impuestos castellanos u otros en sustitución de los mismos; acosados por todo ello, la única salida para muchos fue huir.

Un memorial elevado por la villa de Alcoy, en su nombre y como cabeza de 
una gobernación donde se ubica el condado de Cocentaina, representa las dificultades citadas, por las cuales:

«(...) siguiéndose tantas y tan fatales consecuencias de deserción entera de lugares, como sucede en esta governación de los de Alcoser, Benasau, Alcolecha y Beniafé, y otros que se ven próximos a seguir el mismo triste destino, a dexar sus siempre dulces patrios nidos y buscar en los estraños, con mano mendiga, el corto socorro que les puede subministrar la piedad para el sustento de su miserable vida (...) vaciando las casas de bienes y llenando las cárceles de hombres (...) y lo que se tiene ya por menor mal, las enfermedades epidémicas, las muertes repentinas, efectos todos de la congoxa de el ánimo, causada de la necesidad»(158).

Siempre un memorial solicitando una rebaja de impuestos es sospechoso de parcialidad, pero la huida ante los impuestos viene confirmada en la Instrucción (...) para el repartimiento y cobranza del equivalente de 1718:

"Aviéndose experimentado gran desorden en aver desamparado grande número de vezinos los pueblos de su domicilio por el motivo de éscusarse de pagar el referido equivalente (...) se previene que todas las personas que ayan dexado las vecindades que tenian en cada pueblo desde primero de enero del año de mil setecientos diez y seis, sólo con el motivo expresado de escusarse de pagar el referido equivalente y otros derechos reales, se buelvan a los pueblos de su vezindad y domicilio ${ }^{(159)}$.

La misma Instrucción busca remover alguna de las causas, como puede ser la desigualdad en el reparto - herencia quizá de las rencillas suscitadas en la pasada guerra - pero es dudoso que tuviese gran efectividad, por la sencilla razón de que tras la contienda hay una grave desarticulación económica, si cabe más importante en los lugares de señorío; y a ella hay que atribuir el descenso de la población en las décadas inmediatas más que a los efectos de la elevada mortalidad de los años 1707-1708.

\subsection{Influencia de las crisis de subsistencia}

Carezco para el condado de Cocentaina de series de precios de los productos alimenticios básicos que permitan identificar los años de carestía, cuya inmediata secuela era el hambre afectando a sectores más o menos amplios de la sociedad. Sin embargo, podemos conocer los momentos de especiales dificultades a través de las deliberaciones contenidas en los libros de consells, que cubren, aunque con lagunas, el período que nos interesa.

Una de las funciones primordiales de los jurados era procurar el abastecimiento de la villa, y en los consells y juntas se ocupan a menudo de la compra de trigo, de las dificultades para encontrarlo, de la escasez de la cosecha, de los problemas de la langosta o de las rogativas celebradas ante la adversidad de los elementos. Por mucho que en algunos momentos de su esplendor nos pueda parecer Cocentaina como una villa manufacturera y comercial, ello no supone que viva de espaldas a la actividad agraria. 
No quiero extenderme en una engorrosa enumeración de las múltiples noticias sobre las incidencias de la producción agraria. En lo que ahora interesa, destacar que no aparece una correlación clara entre los años de dificultades en las cosechas y las puntas de mortalidad. A título de ejemplo, valga citar cómo en un consell general celebrado en agosto de 1694, cuando todavía no debía haber finalizado la trilla, hablan de la «poca collita» de ese año y -lo que es un perfecto reflejo de la escasez, por lo inhabitual de decisiones semejantes en tales fechasacuerdan pedir prestadas 2.000 libras para abastecer el almudín local; sin embargo, entre esa fecha y la siguiente cosecha el número de defunciones no se aparta de la media decenal, pese a que en abril de 1695 el síndico exponga al consell «que en la present vila y a molts malals y són perçones de molta vergonya y molt pobres». En marzo de 1696 el párroco del arrabal solicita fondos al consell para «los mols malans (sic) y a en la present vila y la molta nessitat ya y pateixen»; y en junio de 1697 vuelve a hablarse de «res de collita»(160), pero en las series de defunciones no encontramos el reflejo de tales dificultades. Y los ejemplos podrían multiplicarse.

En algunas ocasiones sí que es posible establecer esa relación, aunque no sabemos hasta qué punto es coincidencia: en julio de 1677 el precio del trigo es fijado 150 sueldos el cahíz, a fines de noviembre el consell toma ya medidas proteccionistas y prohíbe su exportación, a fines de diciembre alcanza los 200 sueldos y en abril de 1678 se registran 15 óbitos en la parroquia de Santa María -lo que supone duplicar el número medio de defunciones-y otro tanto sucede en El Salvador ${ }^{(161)}$.

Cabe aducir que un incremento del $40 \%$ en el precio del trigo no es demasiado significativo para la época, aunque el punto de partida sea relativamente alto en comparación con los años inmediatos; sin embargo, destacar que en la documentación municipal no son frecuentes oscilaciones estacionales más importantes ${ }^{162)}$. Podemos entonces ceñirnos a las crisis de subsistencias más importantes localizadas, que son las de 1623 y 1651-1652.

En 1623 hay noticias de fuertes temporales en la primera quincena de marzo - «grans pluges y fortunes de remolins y ayres»-, con tal virulencia como para provocar importantes deterioros en las almazaras, hornos y graneros de la señoría - paredes derruidas y, sobre todo, los tejados en tierra- valorados por expertos en 12.153 sueldos $^{(163)}$. Las consecuencias en las cosechas, presumiblemente, fueron desastrosas.

Tenemos mención de hambre. El 21 de octubre de 1623, el síndico de Cocentaina expone «que en la present vila no y ha vitualles y patixen molta fam, axí los vehins della com los pasatgers» ${ }^{(164)}$.Y también de enfermedades: "per quant a notòria consta que Muro, Selca y demés lochs del present condat estan plens de malalts $)^{(165)}$.

Creeríamos estar ante una crisis de gran magnitud, y que abarcaría varios años, al conocer que en abril de 1623 está despoblado el lugar de Gayanes. Mas cuando la razón argüida es que «los vehins y nous pobladors del dit loch de Gayanes se són morts, y los que restaven han derilinquit del tot lo dit loch per occasió de la mala salut», lo que también habría afectado al vecino lugar de Beniarrés, en el Valle de Perpuchent ${ }^{(166)}$. 
Efectivamente, los registros de defunciones de El Salvador nos hablan de un cierto aumento de defunciones en septiembre, aunque en modo alguno dramático -8 a lo largo del mes, todos albats--; pero después, en los primeros meses de 1624, antes de la nueva cosecha - cuando cabría encontrar las huellas del hambre- el número de defunciones no se aparta de la media. 1624 aparece en el gráfico 2 con una punta de sobremortalidad, pero se explica por los óbitos de septiembre y octubre y no entre enero y mayo, que serían los atribuibles a la pérdida de la cosecha de 1623 .

Esos enfermos de septiembre de 1623 que necesitan de la visita de un médico estarian afectados por una de esas infecciones, con un desarrollo estivo-otonal, tan típicas del área mediterránea. También muy propia de las tierras ribereñas del Mediterráneo es la causa de la despoblación de Gayanes y Beniarrés:

«prop lo loch de Gayanes (...) en part profunda se acostuma fer una gran replega de aygua pluvial y de altres parts, y com ve a estar restanyada y no té ahon discórrer se va a corrompre y infecte lo ayre (...) Del tems que dits lochs estaven poblats de moros hi havia fet uns alcavons per a donar aviament y expedició a la dita aygua restanyada que ve a parar al riu de Alcoy (...) Peró (ahora) estan reblits y enrrunats y se hauran de escurar y netetjar per a que's conseguixca lo benefici del aviament de la dita aygua»(167).

La proximidad de una pequeña cuenca endorreica, cuyos canales de drenaje habían quedado arruinados tras la expulsión de los moriscos, puede constituir razón suficiente como para que la residencia en Gayanes pierda cualquier atractivo: era preciso dar curso a las aguas estancadas para que desapareciese un foco de paludismo que comprometía el éxito de la repoblación inmediata al extrañamiento de los moriscos.

Pero más importancia parece que tiene la crisis de subsistencias de 1651 1652. En diciembre de 1650 el cahíz de trigo ha alcanzado ya los 200 sueldos; poco después, en marzo de 1651, el consell prohíbe la saca de trigo y maíz; pese a lo cual, en mayo aluden a la «molta necesitat y pobres que y ha en la present vila». La cosecha no debe haber sido buena cuando el 25 de junio son aumentadas las penas a quienes intenten sacar granos de Cocentaina; en febrero de 1652 se recurre a un registro de las reservas de granos en poder de particulares y a su puesta a la venta en el almudín municipal; también la villa adquiere 50 cahíces de trigo a 340 sueldos, 25 de maíz a 200 , el 10 de febrero hay una oferta de trigo llegado por mar a Jávea a 260 sueldos $^{(168)}$. Son los precios más altos que tengo documentados para la centuria, y cabría esperar un fuerte aumento de las defunciones, sobre todo en la primera mitad de 1652; sin embargo no es así: El Salvador el número de defunciones está por debajo de la media del decenio, y otro tanto sucede en la de Santa María, donde existe una punta de defunciones en 1651, pero debido exclusivamente a una sobremortalidad de albats.

Son datos dispersos, pero apuntan a que el precio de trigo no es en Cocentaina un «barómetro» demográfico como en el Beauvais ${ }^{(159)}$. Las razones que se pueden aducir son varias. Por un lado existe una producción agraria bastante diversificada, con una relativa importancia de la ganadería y cultivos de huerta menos dependientes de algunos de los caprichos de la metereología mediterránea; ade- 
más, con la introducción del maíz, desde fines del s. XVI se dispone de un cereal panificable con distinto ciclo vegetativo que el trigo. Por otro, al condado llegan los efectos amortiguadores de los precios por la importación de trigo vía marítima; hemos visto cómo la llegada de un barco a Jávea produce la baja de un $25 \%$ en el precio en Cocentaina, en momentos de escasez, y se podrían citar otras situaciones similares; valga como ejemplo uno temprano: a principios de mayo de 1568 los jurados compran 28 cahíces de trigo en Benilloba a 105 sueldos (incluidos portes) y 100 cahíces al colector del conde a 106 sueldos cahíz, «comprat lo qual forment a esdevengut, provehint la misericòrdia divina, que són desembarcades certes naus de forment de Cicília en lo port de la ciutat de Alacant, per les quals és abaxat la formet de la terra a rahó de huytanta sous per cafís e menys ${ }^{(170)}$. En ocasiones, basta la llegada de la noticia precediendo al trigo, los que tienen reservas se apresuran a darles salida bajando los precios.

Todavía se pueden citar otras posibles razones que estarían en el origen de la menor incidencia demográfica de las oscilaciones de la producción cerealista: las diferencias en las fechas de recolección del trigo entre la Montaña y la Vega del Segura, por ejemplo, de que nos habla Escolano(171); la actividad de las autoridades municipales, que no dudan en endeudarse con tal de adquirir las reservas necesarias de grano y hacer los precios asequibles en la medida de lo posible; en el XVII, una mejor distribución de la tierra, que haría que un menor porcentaje de población dependiese normalmente para su sustento de las compras en el mercado; la baja de población, y la mejora de la relación población-recursos, conduciría a una menor sensibilidad a las oscilaciones de las cosechas ${ }^{(172)}$; eso sin olvidar la importancia del arroz en la dieta valenciana ${ }^{(173)}$.

En suma, coincido con la apreciación de Casey: «sembla que la crisi de subsistencies clàssica té menys rellevància per a la història demogràfica del País Valencià que, diguem, per a la de Castella»(174).

Sin embargo, aunque el hambre episódica no tuviese excesiva relevancia, no debemos olvidar la importancia de las disponibilidades habituales de alimentos. Lo difícil es encontrar datos sobre el particular. Su análisis interesa más al capítulo de la mortalidad ordinaria, en la explicación de sus niveles, y de su importancia es buena muestra un texto que pone en relación el hambre, la enfermedad y la desintegración social.

«Per quant en la present vila de Cocentayna y a tot lo present consell és cosa pública y notòria que de algun temps a esta part a vengut molt a menys lo ministeri y exercisi de la perayria, en lo qual se occuparen molts pobres y persones necessitades de naturals y habitadors de la present vila, remediant per est camí sos treballs y necessitat. Y per lo semblant, es cosa pública y notòria que al present se troben en la dita e present vila moltíssimes persones pobres y ab gran necessitat, les quals si no treballen per a altri no podem anidar-se ni sustentar-se, y de partir estes persones y no tenir ab que sustentarse ne an de resultar necessàriament, entre altres, dos inconvenients notables: ço és lo primer que lo comú de la present vila a de affavorir ab moltes charitats entre any a esta gent, senyaladament en lo hospital, perquè $a b$ son mal sustento cauhen en grans malalties; $y$ lo segon que, per occa- 
sió de la molta misèria y necessitat, poden les dites persones descuydar-se en son bon modo de viure y en pendre a fer alguns robos, furts e altres ynsults (...)»)(175).

El texto es de 1607 , es un año de carestía según las series de Hamilton ${ }^{(176)}$, pero aquí no hablan de dificultades coyunturales sino de las derivadas de la crisis de la manufactura contestana, que arroja a la miseria a quienes en ella se ganaban la vida. No importa para ellos que el trigo está caro o barato, son hombres sin tierras, que viven de un jornal, y, si no hay trabajo para poder ganarlo, por mucha abundancia de grano que haya pasarán hambre.

\section{NOTAS}

12.

(1) Pierre CHAUNU Historia y población. Un futuro sin porvenir, F.C.E., México, 1982, p.

(2) Hay autores que tienden a diluir la importancia de las crisis como sujeto de estudio al considerar que, incluso en el caso de las debidas a epidemias como la peste, constituyen una constante en la dinámica habitual de las poblaciones del pasado, en las cuales los años «normales» resultan una excepción (vid. Vicente PEREZ MOREDA: Las crisis de mortalidad en la España interior. Siglos XVI$X I X$. Siglo XXI, Madrid, 1980, pp. 56-58).

(3) No disponemos de una historia actualizada del condado de Cocentaina. Es muy escasa la atención que presta al XVII la clásica de Luis FULLANA MIRA (Historia de la villa y condado de Cocentaina. Monte de Piedad y Caja de Ahorros de Alcoy, Alcoy, $1975-1^{\text {a }}$ ed. de $1920-, 535 \mathrm{pp}$.) e interesan más las obras de Francisco de P. MOMBLANCH Y GONZALBEZ, aunque estudien sólo una de sus localidades: La Segunda Germanía del Reino de Valencia, I.E.A., Alicante, 1957, 161 pp. Historia de la villa de Muro, vol. I (único publicado), I.E.A., Alicante, 1959, $158 \mathrm{pp}$. Sobre el tema de las rentas agrarias, con una sucinta exposición del proceso expulsión-repoblación, puede verse mi trabajo Cartas pueblas valencianas del siglo XVII. I. Cartas pueblas del condado de Cocentaina. Instituto de Estudios «Juan Gil Albert», Alicante, 1985.

(4) P. GUILlaUME y J. P. POUSSOU: Démographie historique. Armand Colin, París, 1970, p. 144.

(5) Vicente PEREZ MOREDA: $O p$. cit., pp. 93 y ss.

(6) Ibid., pp. 100-106. Isabel MOLL y otros: Cronologia de les crisis demogràfiques a Mallorca. Segles XVIII-XIX. Institut d'Estudis Balearics, Palma de Mallorca, 1983, pp. 29-36.

(7) Jean MEUVRET: «Les crises de subsistances et la démographie de la France d'Ancien Régime». Population (Paris), I (1946), pp. 643-650. Véase también Pierre GOUBERT: Beauvais et les beauvaisis de 1600 à 1730. Contribution à l'histoire sociale de la France du XVIIe siècle. Editions de l'Ecole des Hautes Etudes en Sciences Sociales, París, 1982, vol. I, pp. 45 y ss.

(8) Vicente PEREZ MOREDA: Op. cit., p. 72.

(9)) La cosecha del trigo empieza a recogerse, aproximadamente, a mediados de junio en toda esta comarca, de mayor altitud, mientras que en las comarcas meridionales de la provincia de Alicante, al nivel del mar, se adelanta el inicio de la cosecha a principios de mes (Hermann LAUTENSACH: «El ritmo de las estaciones en la Península Ibérica». Estudios Geográficos (Madrid), XVII (1956), p. 457). El momento que los mismos contemporáneos estimaban de precios máximos del trigo era en torno al 20 de mayo, como cabe deducir de las cláusulas contenidas en los contratos de venta al fiado. 
(10) El citar, en concreto, los terremotos es porque en el siglo XVII la comarca estuvo azotada por importantes sismos que causaron daños materiales considerables $\mathrm{y}$, al menos, víctimas en Alcoy (Fernando RODRIGUEZ DE LA TORRE: "Catálogo sísmico de la actual provincia de Alicante (hasta el final del siglo XVIII». Revista del I.E.A. (Alicante), n. ${ }^{\circ} 30$ (1980), pp. 114-115). En el condado no tengo noticia de víctimas, pero sí la confirmación de sus graves consecuencias. Alcocer «a ocasió dels terremotos que $i \mathrm{i}$ aguè en lo any 1617 , resta (...) ab molt poques cases y vasalls y destruït lo terme»; «així mateix, en los terremotos que succehiren en la present ciutat y regne en lo any propassat, succehiren moltes desdiches en lo dit lloch de Alcoseret, de tal manera que a quedat despoblat aquell, sens que hajen restat més de dos o tres cases, y aquelles cassi derrohides (A/rchivo del) R(eino de) V(alencia): Real Audiencia, Procesos, 1/P/1.882, instancia de 28 de agosto de 1644, caps. 8, 17 y 18). Por lo que, a «ocasió dels terremotos que han succehyt en dita baronia se han caygut casi totes les cases de aquella, y estan los dits vasalls sens tenir ahon habitar ni recollir-se» (A.R.V.: Real Audiencia, Procesos, 1/P/1.842, instancia de 17 de diciembre de 1644). Antonio José CAVANILLES (Observaciones sobre la historia natural, geografía, agricultura, población y frutos del reyno de Valencia. Madrid, 1795-1797 - facsímil, Valencia, 1977-vol. I, p. 230) cita los efectos del terremoto de 1645; según este autor, en Cela se hundieron 47 de las 50 casas que tenía y calles enteras en Muro, lo que viene confirmado por el vecindario de 1646, que enumera 13 casas en Cela, «com les demés esten asolades dels terramotos" (A.R.V.: Generalidad, 4.828, cuaderno 437), sin que las relaciones de las demás localidades del condado mencionen pareja circunstancia. Sobre el efecto de los terremotos en Muro, véase Francisco de P. MOMBLANCH Y GONZALVEZ: Historia..., pp. 135-139.

(11) Vicente PEREZ MOREDA: Op. cit., pp. 94-100.

(12) Bartolomé BENNASSAR: Recherches sur les grandes épidémies dans le nord de l'Espagne a la fin de XVI' siècle. Problèmes de documentation et de méthode. S.E.V.P.E.N., Paris, 1969, pp. 65 y ss.

(13) Veánse, los testimonios recogidos por Bartolomé Bennassar en su trabajo antes citado y, con mayor alcance, por Jean Noël BIRABEN: Les hommes et la peste en France et dans las pays européens et méditerranéens. Mouton, París, 1975-1976, 2 vols.

(14) Semejante cláusula es general en todos los arrendamientos, aunque no sé desde qué fecha, el texto está tomado del A(rchivode la) C(atedral de) V(alencia): Protocolos de Antonio Juan Tortrella, año $1656 \mathrm{f}^{\circ} 17 \mathrm{r} .^{\circ} \mathrm{y} v .^{\circ}$.

(15) A(rchivo del) C(olegio del) P(atriarca, Valencia): Protocolos de Guillermo Peris, sig. 1.698, año 1497, sin foliar, escra. de 17 de agosto, cap. 8. A(rchivo) N(otarial de) A(lcoy): Protocolos de Luis Juan Alçamora, 1515, sin foliar, escra. de 2 de enero, cap. 6. Ibíd.; 1516, escra. de 18 de diciembre, cap. 10.

(16) A.R.V.: Real Audiencia, Procesos, 1/P/1.882, doc. A, cap. 19. Ibíd., doc. B, cap. 26.

(17) A(rchivo) D(ucal de) M(edinaceli, Sevilla): Sección Cocentaina, 22/1, ff. ${ }^{\circ} 469$ y ss., cap. 19.

(18) A(rchivo) $\mathrm{M}$ (unicipal de) $\mathrm{C}\left(\right.$ ocentaina): Consells, 5, ff. ${ }^{\circ} 18 \mathrm{r} .{ }^{\circ}-27 \mathrm{v} .{ }^{\circ}$.

(19) El estudio más completo de las epidemias de esta centuria es el de Mercedes GALLENT MARCO: «Valencia y las epidemias del XV». Estudios de Historia Social (Madrid), n. ${ }^{\circ}$ 10-11 (1979), pp. 115-135.

(20) A.M.C.: Consells, 5, f $^{\circ} 27 \mathrm{r} .^{\circ}$.

(21) Agustín ARQUES JOVER: Notas varias y extracto de los notarios, archivos y otros papeles e instrumentos de la villa de Cocentaina, con el principio de la historia de dicha villa y materiales para concluirla. Manuscrito de fines del s. XVIII conservado en el A(rchivo) P(arroquial de) S(anta) M(aría, Cocentaina), vol. I, ff. ${ }^{\circ} 28-29$.

(22) Ibid., vol. $\mathrm{V}, \mathrm{ff} .{ }^{\circ} 60 \mathrm{v} .^{\circ}$ y $64 \mathrm{r} .^{\circ}$ y v. ${ }^{\circ}$.

(23) A.M.C.: Consells, 5 , ff. $.^{\circ} 47 v .^{\circ}-48 \mathrm{r} .^{\circ}$, acta de 23 de junio.

(24) A.M.C.: Consells, $7, \mathrm{f}^{\circ} 11 \mathrm{v} .^{\circ}$.

(25) Bartolomé BENNASSAR: Op. cit., en gen. El análisis más reciente de tal epidemia en Vicente PEREZ MOREDA: $o p$. cit., pp. 257 y ss.

(26) James CASEY: El regne de València al segle XVII. Curial, Barcelona, 1981, p. 23. En este caso, el contagio llegó por vía terrestre, lo cual no quiere decir que no se temiese una posible infección por mar, como lo muestran las medidas pertinentes tomadas en los puertos valencianos. El ejemplo 
de Denia ha sido estudiado por Josep BERNABEU MESTRE: «Epidemia y tráfico marítimo en Denia, 1598: Actes i provisions tocants al morbo o mal contagiós». Comunicación presentada al congreso La Ciudad y el Mar en la Edad Moderna. Murcia/Cartagena, septiembre de 1984..

(27) Juan Bautista PERALES: Décadas de la Historia de la insigne y coronada ciudad y reyno de Valencia escritas por Gaspar Escolano, con gran caudal de notas, ampliaciones aclaratorias y continuada hasta nuestros días por -. Valencia, 1878-1880, vol. III, p. 687. La intervención milagrosa de San Vicente en Agustín ARQUES JOVER: Registro del archivo del convento de San Sebastián de Cocentayna, Manuscrito de fines del s. XVIII conservado en el A.P.S.M., f. ${ }^{\circ} 96 \mathrm{v} .^{\circ}$.

(28) A.M.C.: Consells, 7, ff. $.^{\circ} 207 \mathrm{v} .^{\circ}-208 \mathrm{v} .^{\circ}$.

(29) Agustín ARQUES JOVER: Registro..., f. ${ }^{\circ} 99 \mathrm{r}^{\circ}{ }^{\mathrm{y}} \mathrm{v} .{ }^{\circ}$.

(30) Ibid., f. ${ }^{\circ} 98 \times .^{\circ}$.

(31) El 31 de octubre de 1630 es publicada en Cocentaina la crida con las disposiciones sobre los famosos «polvos» que producían la peste (A.M.C.: Jurats, 1630-1631, f. ${ }^{\circ} 3 \mathrm{v} .^{\circ}$ ). Sobre la actividad de las autoridades valencianas para evitar el contagio, véase Telesforo MARCLAL HERNANDEZ: «Medidas preventivas del reino y de la ciudad de Valencia contra la peste de 1628-1631». Primer congreso de Historia del País Valenciano. Vol. III, Universidad de Valencia, Valencia, 1976, pp. 379-390.

(32) Valencia sería el puerto por el que se introdujo la epidemia en toda la peninsula, según la cronología más comúnmente aceptada a partir del conocido trabajo de JORDI NADAL (La población española. Siglos $X V I$ I $X X$. Ariel, Barcelona, 1976, pp. 41-43). Discrepa en este punto Granjel, quien habla de un primer foco en Andalucía «como reactivación del contagio que en aquella región se mantenía desde 1636" (Luis SANCHEZ GRANJEL: "Las epidemias de peste en la España del siglo XVII". Actas del V Congreso Nacional de Historia de la Medicina. Sociedad de Historia de la Medicina, Madrid, 1977, vol. I, p. 29).

(33) Mariano PESET y otros: «La demografía de la peste de Valencia de 1647-1648». Asclepio (Madrid), n. ${ }^{\circ}$ 26-27 (1974-5), pp. 197-231. La bibliografia sobre esta epidemia, que es la mejor estudiada de las que afectaron al reino de Valencia, cuenta con un buen número de apreciables trabajos cuya referencia se puede consultar en la «Introducción» de Mariano PESET a la obra de Francisco GAVALDA: Memoria de los sucessos particulares de Valencia y su reino en los años de mil seiscientos cuarenta y siete y cuarenta y ocho, tiempo de peste. Valencia, 1651, ed. facsímil, Librerías ParísValencia, 1979. Relación a la que cabe añadir el estudio más reciente de Santiago LA PARRA: Tiempo de peste en Gandía (1648-1652). Ajuntament de Gandia, Gandia, 1984, 109 pp.

(34) A.M.C.: Jurats, 1647-1648, "provisions», ff. ${ }^{\circ} 20 \mathrm{v} .{ }^{\circ}-21 \mathrm{r} .{ }^{\circ}$ Tres dias después, en Muro son celebradas rogativas a San Roque, según las notas tomadas por Francisco de $\mathbf{P}$. Momblanch y Gonzálvez de documentación hoy desaparecida. Notas cuya consulta debo a la amabilidad de su hijo, don Francisco Momblanch García.

(35) A.M.C.: Consells, 12, ff. ${ }^{\circ} 132-134$.

(36) A.M.C.: Jurats, $1647-1648, f .^{\circ} 21 \mathrm{r}^{\circ}$ y v. ${ }^{\circ}$ (12 de septiembre de 1647).

(37) A.M.C.: Cort del procurador, 1647, «memorials», cuadernillo entre ff. ${ }^{\circ} 24$ y 25 . Actuaciones similares en Muro documenta Momblanch, quien habla de una crida publicada en Játiva, Cocentaina y Muro (en septiembre) de la que no tengo otra noticia; quizá sea la general dispuesta por las autoridades de Valencia. Anotar que todavía hay un valenciano refugiado en Muro el 1 de diciembre de 1647 (Francisco de P. MOMBL ANCH Y GONZALVEZ: Historia..., p. 141).

(38) Santiago LA PARRA: Op. cit., p. 39. Luis GARCIA BALLESTER y José M. ${ }^{a}$ MAYER BENITEZ: «La peste de Orihuela de 1648. Nota previa». Primer Congreso de historia del País Valenciano. Vol. III. Universidad de Valencia, Valencia, 1976, pp. 393-394.

(39) Vicente GOZALVEZ PEREZ: «Notas sobre demografia de la provincia de Alicante». Cuadernos de Geografia (Valencia), 11 (1972), p. 30. Santiago LA PARRA: Op. cit., pp. 41 y 101. Luis GARCIA BALLESTER y José M. ${ }^{2}$ MAYER BENITEZ: «La peste...», pp. 393-395.

(40) Agustin ARQUES JOVER: Registro..., ff. $.^{\circ} 93 \mathrm{v} .{ }^{\circ}-94$ r. ${ }^{\circ}$. Es una cita textual del Libro Racional. También en sus Notas..., vol. IV, f. ${ }^{\circ} 249$.

(41) A.M.C.: Consells, $12 \mathrm{ff}^{\circ} 164 \mathrm{r}^{\circ}-165 \mathrm{v}^{\circ}$

(42) Ibid. Días después el 30 de junio, pese a la evidencia del contagio, siguen tomando medidas igualmente drásticas para alejar de Cocentaina a posibles portadores de la peste. En tal fecha son 
expulsados, al no querer cumplir cuarentena, unos arrieros que venían de Játiva y «terres infectes» sin el correspondiente certificado de sanidad. Las penas, de incumplir el mandato, son de tres años de destierro; y para unos de ellos, que es vecino de Cocentaina, la amenaza es la pena de muerte ibid., f. ${ }^{\circ}$ $\left.166 \mathrm{r}^{\circ}{ }^{\mathrm{y} \mathrm{v}} .^{\circ}\right)$.

(43) Ibid., ff. ${ }^{\circ} 165 \mathrm{v} .^{\circ} 166 \mathrm{r} .^{\circ}$.

(44) Ibid., f. ${ }^{\circ} 166 \mathrm{r} .^{\circ}$.

(45) De las dramáticas consecuencias que podía acarrear la incomunicación, condenando al hambre a los vecinos de las localidades sobre las que recaía la sospecha de estar apestadas $-\mathrm{y}$ los intentos para evitarla a toda costa-, pueden encontrarse ejemplos en Henry KAMEN: La España de Carlos II. Ed. Crítica, Barcelona, 1981, pp. 90 y 94. Y en Antonio CARRERAS PANCHON: La peste y los médicos en la España del Renacimiento. Ediciones del Institu to de Historia de la Medicina Española, Salamanca, 1976 , p. 148.

(46) Antonio CARRERAS PACHON: Op. cit., pp. 59-65 Gavaldá menciona discusiones semejantes entre los médicos de Valencia (Francisco GAVALDA: Op. cit., puntos I-III).

(47) A.M.C.: Consells, 12, f. ${ }^{\circ} 169 \mathrm{r} .^{\circ}$.

(48) Agustín ARQUES JOVER: Notas..., vol. IV , f. ${ }^{\circ} 248 \mathrm{r}^{\circ}{ }^{\circ}$, transcribiendo una anotación literal del Libro Racional de 1648 . Poco antes, en el mismo manuscrito (f. ${ }^{\circ} 246 \mathrm{v} .^{\circ}$ ), cita de un «libro de sepulturas» de 1648 la siguiente nota: «en 1 de juny de 1648 entra el mal de la pesta»; demasiada precisión, quizá se refiera a la fecha de defunción de la primera víctima, o también explicarlo porque estas últimas referencias parecen extractos apresurados del texto transcrito.

(49) Pues no es posible conocer las fechas de fallecimiento de los apestados: en el caso de las de adultos porque sólo disponemos de la cita de Arques; en el de las de albats porque en el quinque libri sólo consta una relación de los fallecidos a causa de la peste, indicando que son enterrados -y algunos allí mueren - en la «cassa blanca», sin hacerse cargo de ellos el colector. La única forma de aproximarnos al conocimiento de los momentos de mayor incidencia de la epidemia es a través de la discontinuidad de otras series documentales (vid. infra $\mathrm{n}$. 59).

(50) A.M.C.: Consells, $12, \mathrm{f}^{\circ} 173 \mathrm{v} .^{\circ}$.

(51) Ibíd., f. ${ }^{\circ} 174 \mathrm{v} .^{\circ}$ la referencia a la vuelta de la peste es explícita en el consell de $18 \mathrm{de}$ diciembre: «en algunes cases de la present vila y arraval ha tornat lo mal contagiós»; en el cual también acuerdan satisfacer el salario a quien «a acudit a enterrar algunes persones estos dies, per quemar roba y que sia de dur lo menjar als que estan en Sant Christòfol per lo dit mal contaxiós y altres coses que li toquen a fer». El 8 de enero, la junta de la peste hace saber al clero parroquial que quienes vayan a Benilloba para conducir el cadáver del párroco de ese localidad a Cocentaina, porque «és mort ab perill de mal contaxiós», deberán guardar cuarentena (ibid., ff. ${ }^{\circ} 183 \mathrm{v} .{ }^{\circ}-184 \mathrm{r}^{\circ}$ ). Sobre la duración del nuevo brote, en agosto de 1649 hablan de los gastos originados por el contagio "per a als ferits y malalts (...) en lo any propassat y principi del present any» (ibid., ff. ${ }^{\circ} 208 \mathrm{v}^{\circ} 209 \mathrm{r}^{\circ}$ ).

(52) Ibid., f. ${ }^{\circ} 192$ v. ${ }^{\circ}$.

(53) Francisco de P. MOMBLANCH Y GONZALVEZ: Historia..., , p. 142. Tambièn en su $L a$ Segunda Germanía..., p. 34.

(54) Francisco de P. MOMBLANCH y GONZALVEZ: Historia..., pp. 144-145.

(55) Vid. infra «El impacto de la peste».

(56) Jean Noël BIRABEN: Op. cit., vol. I, cap. IV.

(57) Distintos ejemplos en Bartolomé BENNASSAR: Op. cit., pp. 24, 52 y 76.

(58) En el volumen 12 de consells están en blanco los folios $134 \mathrm{v} .{ }^{\circ}$ a $164 \mathrm{v} .^{\circ}$, laguna que no puede relacionarse directamente con la peste, pues las anotaciones se reinician el 22 de junio de 1648 , cuando la epidemia empieza a manifestarse con todo su rigor.

(59) El impacto de la peste sí que cabe seguirlo en los registros de la curia del justicia -el supremo magistrado local - que quizá estuviese paralizada en los momentos culminantes de la epidemia. Así, ningún embargo ejecutivo es instado entre el 13 de junio y el 6 de octubre, y la serie carece de continuidad desde el 27 de mayo al 22 de octubre. Tampoco consta que el justicia dictase ninguna provisión entre el 17 de julio y el 26 de septiembre (A.M.C.: Cort del justícia, 1648).

(60) A.M.C.: Consells, $12, \mathrm{f}^{\circ} 193 \mathrm{v} .^{\circ}$.

(61) Para celebrar un consell en Muro el 7 de octubre de 1648, el gobernador del condado da la 
preceptiva licencia desde Bocairente, «donde a causa de la peste se había refugiado» (Francisco de $\mathbf{P}$. MOMBLANCH Y GONZALVEZ: Historia..., p. 143).

(62) Agustín ARQUES JOVER: Registro..., f. ${ }^{\circ} 10 \mathrm{r} \cdot{ }^{\circ}$ Sobre la actitud del clero en otras localidades valencianas véase Luis GARCIA BALLESTER y José M. ${ }^{a}$ MAYER BENITEZ: «La peste...», pp. 395-397. Y Mariano PESET y otros: «El clero ante la peste de Valencia de 1647-1648». Anales Valentinos (Valencia), n. ${ }^{\circ} 4$ (1976), pp. 307-343.

(63) A.M.C.: Consells, $12, \mathrm{ff}^{\circ} 169 \mathrm{r} .^{\circ}$ y v. ${ }^{\circ}$.

(64) La frase es de Martínez de Leyva en 1597, pero distintas versiones sobre un mismo mensaje las encontramos con profusión desde la baja edad media hasta el siglo XIX, traspasada entonces la recomendación a la actitud ante el cólera (Antonio CARRERAS PANCHON: Op. cit., pp. 91 y ss. Jean Noël BIRABEN: Op. cit., vol. II, pp. 160-167.

(65) Agustín ARQUES: Notas..., ms., vol. IV, f. $24^{\circ} \mathrm{r} .{ }^{\circ}$, citando textualmente el Libro Racional de la parroquia de Santa María.

(66) Cit, por Antonio CARRERAS PANCHON: Op. cit., p. 94.

(67) Loc. cit. infra nn. 73 y 98.

(68) A.M.C.: Cort del justícia, 1649, «memorials», f. ${ }^{\circ} 22$ r. ${ }^{\circ}$. En Cocentaina existía un hospital administrado por el consell y el párroco, con una situación económica precaria por la dificultad de cobrar los intereses de los censales. No parece que fuese utilizado durante la epidemia de peste, quizá por no ofrecer las condiciones necesarias de aislamiento. De todas formas, decir que era del todo punto insuficiente: los periódicos inventarios elaborados al tomar posesión de su cargo los mayordomos indican un número de camas en torno a la media docena, incluyendo los simples jergones.

(69) A.M.C.: Consells, $\mathrm{n} .{ }^{\circ} 13, \mathrm{f}^{\circ} 6 \mathrm{v} .^{\circ}$.

(70) Ibid., ff. ${ }^{\circ} 171 \mathrm{v},{ }^{\circ}$ y $196 \mathrm{v} .{ }^{\circ}-197 \mathrm{r} .^{\circ}$. He ilevado a cabo la identificación de los lugares destinados a los apestados y convalecientes a través de las posteriores referencias de gastos para su purificación o para compensar a sus dueños de las pérdidas sufridas.

(71) Ibid., ff. ${ }^{\circ} 209 \mathrm{r}^{\circ}-210 \mathrm{v} .^{\circ}$.

(72) Francisco de P. MOMBLANCH: La Segunda Germania..., p. 34.

(73) La cita en A.M.C.: Consells, $12, \mathrm{ff}^{\circ}{ }^{\circ} 209 \mathrm{r} .{ }^{\circ} 210 \mathrm{v} .^{\circ}$; vid. también, en el mismo volumen, ff. ${ }^{\circ} 207$ y v. $^{\circ} 208$ v. $^{\circ}-209$ r $^{\circ} 252$ r. $^{\circ}$ y 282 r. $^{\circ}$.

(74) Según una nota de 21 de mayo de 1649, fue contratado por 3 meses y un salario de 130 libras al mes. Por el posterior brote de diciembre cobró 49 libras, remuneración sensiblemente inferior, quizá por la menor virulencia de la epidemia en estas fechas (A.M.C.: Consells, 12, f. $^{\circ} 192 \mathrm{v}^{\circ}{ }^{\circ}$ ). Como punto de comparación, téngase presente que el gobernador del condado, máximo cargo señorial, percibía 200 libras al año.

(75) Loc. cit. supra n. 62.

(76) A.M.C. Consells, 12, f. ${ }^{\circ} 174 \mathrm{v} .^{\circ}$.

(77) A.M.C. Cort del procurador, año 1648 , «memorials», f. ${ }^{\circ} 14 \mathrm{v} .{ }^{\circ}$. Hay dos casos más (ibíd. ff. ${ }^{\circ} 15 \mathrm{r} .{ }^{\circ}$ y v.$^{\circ}$ ) que se obligan, dando fianzas, a volver a la cárcel siempre que se lo ordenen, aunque no indica que deben prestar servicios en la casa blanca; quizá se trate tan sólo en este caso de eliminar un posible foco de infección en las cárceles. Soluciones semejantes, u otras no menos excepcionales - como el comprar esclavos para servir de morberos-, se repiten en distintas localidades afectadas (véase, para Valencia, Francisco GAVALDA: Op. cit., punto IV).

(78) Francisco de P. MOMBLANCH: Historia..., pp. 143-146.

(79) A.M.C.: Consells, 12 , ff. ${ }^{\circ} 169 \mathrm{r} .{ }^{\circ}$ y v.$^{\circ}$ y $171 \mathrm{v} . \circ$

(80) Ibid., ff. ${ }^{\circ} 196 \mathrm{v}^{\circ}-197 \mathrm{r}^{\circ}$.

(81) Ibid., ff. ${ }^{\circ} 170 \mathrm{v} .^{\circ}-171 \mathrm{v} .^{\circ}$.

(82) Ibíd., f. ${ }^{\circ} 177$.

(83) Agustin ARQUES JOVER: Notas..., vol. IV, f. ${ }^{\circ} 248 \mathrm{r} .^{\circ}$. De todas formas indicar que siempre existe una cierta indeterminación en este tipo de datos, pues no podemos verificar los diagnósticos y conocer su fiabilidad. En estas condiciones, es posible - sobre todo en los primeros momentos de la epidemia - que algunos apestados no fueran identificados como tales $\longrightarrow$ fuese ocultada su enfermedad-; en sentido contrario opera la posibilidad de que los fallecidos por otras enfermedades infecciosas, mal identificadas, fuesen contabilizados entre los apestados. Recordar que Fran- 
cisco GAVALDA (Op. cit., cap. II) habla de que «también tuvo en este tiempo tercianas y otros accidentes, aunque pocos; pero los malignos y mortales sólo fueron los primeros (la peste)».

(84) La estimación de las tasas de mortalidad la he hecho siguiendo la vía ya indicada para calcular la incidencia de las crisis de mortalidad en general.

(85) Hay noticias de que, efectivamente, hubo un cierto número de afectados a principios de 1649 (vid. supra $\mathrm{n}$. 51). De todas formas, la corta duración del nuevo brote y la estación en que se produjo, la misma continuidad de todos los actos de la vida local y la poca atención que le prestan en los consells, hacen suponer que tuvo escasa incidencia; $y$, de hecho, el total de defunciones de 1649 registra valores moderados.

(86) Los apestados no fueron enterrados en la iglesia por el peligro de infección, sino en el Pla de la Font -donde estaba la "cassa blanca»- razón por la cual es cerrado para el ganado (A.M.C.: Consells, $12, \mathrm{f}^{\circ} 171 \mathrm{v} .^{\circ}$ ) y no puede desecharse que quienes murieron en las casas de campo fuesen enterrados en su proximidad, sin otro requisito.

(87) Francisco de P. MOMBLANCH Y GONZALVEZ: La Segunda Germania..., p. 34.

(88) Son cuatro los fallecidos en agosto -el primero el día 3-, uno en septiembre y otro en diciembre. En las respectivas actas, para justificar el sepelio fuera de la iglesia, el párroco menciona la causa de su muerte: «mori de mal de peste», «ser mort en casa empestada» o "ser mort de contagi». En dos ocasiones indica que las disposiciones testamentarias del difunto, «per no aver-i comoditat de notari, en presència de tres testimonis, el rebí yo mosèn Jeroni Barrachina, retor de dit poble»» (A(rchivo) P(arroquial) de La A(lcudia): Quinque libri, 2, «libro de defunciones, año 1648).

(89) A.M.C.: Consells, $12, \mathrm{f}^{\circ} 237 \mathrm{v} .^{\circ}$.

(90) En Valencia perecería entre el 27 y el $34 \%$ de la población (Mariano PESET y otros: «La demografia...», p. 220) y en Orihuela hasta el 50\% (Luis GARCIA BALLESTER y José M.a MAYER BENITEZ: «La crisis demográfica y de subsistencias y las medidas sanitarias de carácter colectivo en la peste de Orihuela de $1648 \%$. Primer Congreso de Historia del País Valenciano, vol. III. Universidad de Valencia, Valencia 1976, pp. 402-403), aunque ésta es una estimación criticada en el trabajo primero citado (pp. 220-221, n. 28) como resultado de datos erróneos, y las pérdidas reales estarían entre el 23 y el $30 \%$. De todas formas, apuntar que tanto en Valencia como en Orihuela es dificil evaluar la mortalidad atribuible a la peste de forma precisa, por los problemas ya mencionados: huida de la población, entierros fuera de todo control.

(91) James CASEY: Op. cit., p. 23. No es necesario insistir sobre lo aproximado de semejante estimación.

(92) En Cocentaina, la peste, dentro de la pobreza de los datos disponibles, afecta sobre todo a los adultos -sólo el 20\% son albats-, aunque no es posible determinar con mayor precisión las edades de los fallecidos. Apuntar que la disminución de las medias de bautizados (cuadro 1) indican que la incidencia de la peste sería menor en la parroquia de El Salvador que en la de Santa María; y es interesante hacerlo porque en ésta residen los de situación económica más desahogada, pero tambien registra un mayor abanico de situaciones socioprofesionales, mientras que en la parroquia de El Salvador viven los inmediatos descendientes de quienes vinieron a sustituir a los moriscos expulsados en 1609.

(93) La partida más importante es la que reclama Miguel Espinós, apotecari: 1.200 libras «per lo preu de les medicines que han servit per a els malalts del contagi en la cassa blanca y en altres parts», que también parece incluir el sustento de los enfermos; una cantidad que los jurados logran que reduzca a 500 libras. Aparte están las 349 libras pagadas al médico, las 29 por los locales de la "casa blanca", 10 libras de alquiler de la almazara para los convalecientes, 36 libras 17 sueldos por gastos de ropa y otras cantidades menores o mal identificadas. En Muro los gastos son menores: 164 libras para el médico y cirujanos, 39 libras 15 sueldos para los enterradores, 30 libras para medicinas y 122 libras 15,5 sueldos por el abasto de la «casa blanca» (loc. cit. supra nn. 60, 68-70, 73-74 y 78).

(94) A.M.C.: Consells, $12, \mathrm{ff}^{\circ} \mathrm{r}^{\circ}-169 \mathrm{v} .^{\circ}$.

(95) Ibid., ff. ${ }^{\circ} \mathrm{r}^{\circ} \mathrm{y} \mathrm{v}^{\circ}$ y $133 \mathrm{v} .^{\circ}-134 \mathrm{r} .^{\circ}$.

(96) Ibid., f. ${ }^{\circ} 171 \mathrm{v} .^{\circ}$.

(97) Ibid., ff. ${ }^{\circ} 207 \mathrm{r}^{\circ}$ y v ${ }^{\circ}$ y $209 \mathrm{r}^{\circ}-210 \mathrm{v} .^{\circ}$. Se cita un memorial de 9 de agosto en el que anotarían los gastos médicos y de mantenimiento de todos los afectados. Sólo nos ha llegado alguna noticia indirecta de las cantidades tachadas, cuando a uno $u$ otro de los acreedores de la villa les son con- 
signadas en pago de su crédito las sumas que los particulares adeudaban por causa del contagio, y algunas de ellas son relativamente importantes.

(98) Al menos hasta 1654, cuando son reclamadas judicialmente junto a los intereses devengados (A.M.C.: Consells, $13, \mathrm{ff}^{\circ}{ }^{\circ} 6,8 \mathrm{v} .^{\circ}-9 \mathrm{r} .{ }^{\circ}, 10 \mathrm{v} .^{\circ}, 30,36 \mathrm{r} .^{\circ}$ y v $.^{\circ}, 43 \mathrm{r} . .^{\circ}$ y v ${ }^{\circ}, 47 \mathrm{v} .{ }^{\circ}-48 \mathrm{v} .^{\circ}, 49$ $v^{\circ}-50 \mathrm{r} .^{\circ}$ y $\left.59 \mathrm{r}^{\circ}\right)$. En Muro también obtuvieron del conde un préstamo de 200 libras para hacer frente a los gastos de la epidemia (Francisco de P. MOMBLANCH Y GONZAL VEZ: Historia..., pp. 143 y 146-147).

(99) Jordi NADAL: Op. cit., p. 42.

(100) Antonio MESTRE SANCHIS: «Estudio de la demografia de Oliva a través de los archivos parroquiales después de la expulsión de los moriscos». Estudis (Valencia), 1 (1972), p. 177.

(101) Emilio LA PARRA: Tiempo de peste en Gandia, ya citado.

(102) En 1651 observamos un aumento de los óbitos especialmente sensible en la parroquia de Santa María, pero que no es atribuible a la peste (vid. infra, 2.2).

(102 bis) Emilio LA PARRA: Op. cit., pp. 42, 65 y 105.

(103) Jordi NADAL: Op. cit., p. 42.

(104) Jesús MAISO GONZALEZ: La peste aragonesa de 1648 a 1654. Departamento de Historia Moderna, Zaragoza, 1982, pp. 41-54.

(105) A.M.C.: Jurats, 1652-1653, correspondencia, f. ${ }^{\circ} 3$ r. ${ }^{\circ}$.

(106) A.M.C.: Consells, $12, \mathrm{ff}^{\circ} 314 \mathrm{r} .{ }^{\circ}-315 \mathrm{r} .^{\circ}$..

(107) Ibid., f. $315 \mathrm{r} .^{\circ} \mathrm{y} \mathrm{v}^{\circ}$.

(108) Ibid., ff. ${ }^{\circ} 316$ y ss. Medidas reiteradas el 11 de agosto, pese a las protestas de los arrendatarios de las sisas.

(109) A.M.C.: Jurats, 1652-1653, correspondencia, f. ${ }^{\circ} 4$ r. $^{\circ}$.

(110) Ibid., f $.^{\circ} 3 \mathrm{r} .{ }^{\circ}$. La vecina villa se declara «agraydísima del mol cuydado y bon sel tenen V. Ms. en fer-nos mersed de avisar-nos del mal de Gandia y Rafelcofer, y per ell los besam la mà».

(111) Ibid., f. ${ }^{\circ} 6 \mathrm{r} .{ }^{\circ}$ (2 de agosto de 1652).

(112) A.M.C.: Consells, $12, \mathrm{f}^{\circ} 319 \mathrm{r} .^{\circ}$.

(113) Ibid., ff. ${ }^{\circ} 319 \mathrm{r}^{\circ}-321 \mathrm{r}^{\circ}$; deliberaciones de 9,11 y 17 de agosto.

(114) A.M.C.: Jurats, 1652-1653, correspondencia, f. ${ }^{\circ} 8 \mathrm{r}^{\circ}$.

(115) A.M.C.: Consells, $12, \mathrm{f}^{\circ} 322 \mathrm{r}^{\circ}$.

(116) Una relación de los fallecidos en la «casa blanca» incluye los óbitos entre el 15 de julio y el 9 de agosto. Quizá sean éstos los momentos de mayor incidencia de la epidemia, pero el duque de Gandía no volverá a su palacio hasta el 27 de septiembre, después de haberse cercionado de la salud de la villa (Santiago LA PARRA: Op. cit., pp. 76 y 105).

(117) Un planteamiento general en Henry KAMEN: Op. cit., pp. 79-90.

(118) Insistir en la rapidez de propagación de las noticias. Es a mediados de junio cuando en Cartagena se detecta un número anormalmente alto de defunciones, y el 23 de junio es un tema que ocupa por primera vez al Consejo de Aragón (Henry KAMEN: Op. cit., pp. 79-80); el 24 del mismo mes los munícipes de Orihuela remiten a Cartagena un médico y un cirujano, y no será hasta el 27 cuando llegue la confirmación de que es una epidemia similiar a la de 1648 (Mario MARTINEZ GOMIS: «La larga espera de la muerte en una ciudad valenciana del siglo XVII (Orihuela ante la peste de 1676-1678)». Anales de la Universidad de Alicante. Historia Moderna (Alicante), 2 (1982), p. 137).

(119) A.M.C.: Consells, $15, \mathrm{f}^{\circ} 691 \mathrm{r}^{\circ}$ y v.$^{\circ}$.

(120) Ibíd., f. ${ }^{\circ} 692 r{ }^{\circ}$. Uno de los electos es el párroco de Santa María, pero no aparece en esta ocasión ningún representante sef́orial; y este nombramiento será ratificado por el inmediato consell general (ibid., f. $\left.{ }^{\circ} 694 \mathrm{r}^{\circ}\right)$.

(121) Ibid., f. ${ }^{\circ} 717 \mathrm{r}^{\circ}$.

(122) Henry KAMEN: Op. cit., pp. 79-80.

(123) A.M.C.: Consells, 15 , ff. $.^{\circ} 742 \mathrm{v}^{\circ}{ }^{\circ}-743 \mathrm{r} .^{\circ}$ y $746 \mathrm{v} \cdot{ }^{\circ}-747 \mathrm{r} .^{\circ}$. Son seis los «elets» para la junta, sin que entre ellos se encuentren representantes del clero o de la administración senorial, aunque después sí que aparezca su intervención (vid. infra $\mathrm{n} .128$ ). 
(124) Para todo lo referente al cordón sanitario véase Mario MARTINEZ GOMIS: Op. cit., pp. 135-166.

(125) A.M.C.: Consells, $15, \mathrm{f}^{\circ} 750 \mathrm{r} .^{\circ}$.

(126) Ibid., f. ${ }^{\circ} 752 \mathrm{r}^{\circ}$.

(127) Ibid., ff. ${ }^{\circ} 743 \mathrm{r}^{\circ}-744 \mathrm{r} .^{\circ}$.

(128) Ibid., f. $.^{\circ} 751 \mathrm{r} .^{\circ}$ y v. ${ }^{\circ}$. Mientras la crida antes citada es publicada exclusivamente de orden del justicia y los jurados, en la elaboración y promulgación de estas ordenanzas interviene una junta compuesta por los oficiales de la villa, electos de la peste, titulares de ambas parroquias y el gobernador señorial.

(129) A.M.C.: Consells, $16, \mathrm{f},{ }^{\circ} 1 \mathrm{r} .^{\circ}$ y v. ${ }^{\circ}$. Debemos tener en cuenta que todavía el 12 de mayo un médico comisionado por Valencia dictaminaba que no era peste, y el 17 aún se discutía sobre la condición de la epidemia (Mario MARTINEZ GOMIS: Op. cit. pp. 146 y ss).

(130) A.M.C.: Consells, $16, \mathrm{ff}^{\circ}{ }^{\circ} 1 \mathrm{v} .^{\circ}-2 \mathrm{r} .^{\circ}$. En esta ocasión son siete los «elects», incluyendo el nombramiento municipal a los párrocos de Santa María y El Salvador y al gobemador del condado.

(131) Ibid., f. ${ }^{\circ} 16 \mathrm{v} .^{\circ}$.

(132) Antonio CARRERAS PANCHON: Op. cit., pp. 59 y ss. Jesús MAISO GONZALEZ: Op. cit., pp. 29 y ss.

(133) En concreto, los años de sobremortalidad en el período 1609-1709 son los siguientes (por año civil y expresados en \%o). En la parroquia de Santa María: $1625=47^{\prime} 9,1627=54,1648=153^{\prime} 1$, $1651=62^{\prime} 4,1658=40^{\prime} 7,1665=50^{\prime} 4,1666=54^{\prime} 3,1668=48,1672=49^{\prime} 8,1678=49^{\prime} 1,1680=40^{\prime} 2$, $1681=48^{\prime} 4, \quad 1703=55^{\prime} 1, \quad 1706=42^{\prime} 2, \quad 1707=85^{\prime} 5$ y $1708=60^{\prime} 8$. Parroquia de El Salvador: $1616=61^{\prime} 1,1619=46^{\prime} 6,1624=48^{\prime} 9,1625=58^{\prime} 9,1651=54^{\prime} 5,1658=44^{\prime} 3,1681=58^{\prime} 3$. Parroquia de La Alcudia: $1643=64^{\prime} 3,1648=60^{\prime} 9,1651=43^{\prime} 5,1658=57^{\prime} 1,1659=100,1664=66^{\prime} 7,1667=53$, $1673=62^{\prime} 5,1678=88^{\prime} 9,1687=54^{\prime} 1$ y $1689=64^{\prime} 3$. Parroquias de Alcocer y Gayanes: $1705=42^{\prime} 6$ y $1707=109^{\prime} 5$.

(134) Parroquia de Santa María: $1625=42^{\prime} 3,1626=51^{\prime} 6,1627=42^{\prime} 4,1672=40^{\prime} 6$, $1677=45^{\prime} 6,1681=41^{\prime} 4,1701=42^{\prime} 2,1703=57^{\prime} 2,1706=85^{\prime} 3$ y $1707=84^{\prime} 8$. Parroquia de El Salvador: $1615=58^{\prime} 2,1619=44^{\prime} 9,1623=42^{\prime} 7,1624=63^{\prime} 4,1625=40^{\prime} 7,1677=51^{\prime} 6,1681=42^{\prime} 5$, $1685=42^{\prime} 2$ y $1688=41^{\prime} 4$. Parroquia de La Alcudia: $1648=63^{\prime} 1,1651=51^{\prime} 5,1658=76^{\prime} 9,1659=58$, $1666=44^{\prime} 1,1672=54^{\prime} 7,1673=41,1678=91^{\prime} 5,1680=48^{\prime} 6,1686=61^{\prime} 2,1689=64^{\prime} 7$ y $1703=46^{\prime} 7$. Parroquias de Alcocer y Gayanes: $1706=90$ '9 y $1707=61$ '2. Sobre la forma de calcular el número de concepciones, matrimonios y defunciones por año-cosecha véase Michel FLEURY y Louis HENRY: Noveau manuel de dépouillement et d'exploitation de l'état civil ancien. Editions de l'Institut National d'Etudes Démographiques, París, 1976, pp. 99-103; aunque con las modificaciones impuestas por la diferencia de fechas de recolección del trigo (vid. supra n. 9).

(135) En la parroquia de La Alcudia no tiene especial reflejo la crisis de 1707, pero sus datos deben ser tomados con las mayores reservas: por un lado en razón de su escasa representatividad estadística, por otro - y principalmente - porque la cabecera parroquial figura como casi despoblada tras la guerra; y así, en la toma de posesión del condado en 1717 se dice que La Alcudia «al presente está derruido y con muy pocas casas» (A.D.M.: Protocolos de Andrés Císter, sig. M/7, ff. ${ }^{\circ} 147$ r. ${ }^{\circ}-149$ r. $\left.{ }^{\circ}\right)$.

(136) Vicente GASCON PELEGRI: La región valenciana en la Guerra de Sucesión. Suc. de Vives y Mora, Valencia, 1956, pp. 173 y ss. Julio BERENGUER BARCELO: Historia de Alcoy. Alcoy, 1977 , vol. I, pp. 393 y ss.

(137) A.P.A.: Quinque libri, 2, libro de defunciones, acta de 5 de julio de 1707.

(138) Carmen PEREZ APARICIO: «La sanidad municipal valenciana en el período 1\%051709). III Congreso Nacional de Historia de la Medicina, vol. II. Sociedad Española de Historia de la Medicina, Valencia, 1971, p. 203.

(139) Julio BERENGUER BARCELO: Op. cit., vol. I, pp. 391-392 y 396.

(140) A(rchivo) N(otarial de) C(ocentaina): Protocolos de Roque Reig, vol. 1706-1707, año 1707 , ff. ${ }^{\circ} 66 \mathrm{v} \cdot{ }^{\circ}-68 \mathrm{v} .^{\circ}$. Todas las citas a esta visita pertenecen a la misma acta.

(141) Ibid., ff. ${ }^{\circ} 130 \mathrm{r} .^{\circ}-131 \mathrm{v} .^{\circ}$. 
(142) A.M.C.: Libro de libramientos y mandatos, años 1707-1732 (iniciado con la nueva administración filipista), sin foliar, mandatos nn. ${ }^{\circ} 24,26$ y 36.

(143) Agradezco a D. Josep Bernabeu Mestre, del Departamento de Historia de la Medicina de la Universidad de Alicante, las indicaciones para la identificación de la epidemia.

(144) Kamen recoge el diagnóstico de un médico de la época sobre la epidemia que afectaba en 1707 a las ciudades de Cartagena, Murcia y Orihuela: «en estas tres ciudades las en fermedades son de una misma especie, epidemia de calenturas perniciosas malignas (... con) muchos sudores, pintas de varios colores, rubias, oscuras y negras, sin carbunco ni bubón» (Henry KAMEN: La Guerra de Sucesión en España. 1700-1715. Grijalbo, Barcelona, 1974, p. 393). Y en Alicante «los enfermos comenzaban por sentir un accidente en la cabeza que acababa por privarles el sentido" (Rafael VIRAVENS PASTOR: Crónica de la muy ilustre y siempre fiel ciudad de Alicante. Alicante, 1876 -ed. facsímil, 1976- p. 290). Vemos que la relación de los síntomas coincide con la del doctor Caudi para Cocentaina. Sobre la posible incidencia del tifus en el centro de Castilla, en relación con ese foco endémico que suponen los ejércitos de la época, véase Vicente PEREZ MOREDA: Op. cit., pp. 329 y ss. Dada la extensión de esta crisis, destaca que en Mallorca no encuentre especial reflejo (Isabel MOLL y otros: Op. cit., pp. 51 y ss.).

(145) Vicente PEREZ MOREDA: Op. cit., pp. 71-72.

(146) A.M.C.: Consells, $18, \mathrm{f}^{\circ} 363 \mathrm{v}^{\circ}$.

(147) Ibid., f. ${ }^{\circ} 365 \mathrm{r}^{\circ}$.

(148) A.M.C.: Acuerdos, 1, f. $^{\circ} 1$.

(149) Recordar que nos encontramos en unos momentos de carestía generalizada en Europa debido a la pérdida de las cosechas. Carestía agravada en Valencia por los efectos de una guerra cuyos rescoldos aún no se han apagado del todo, con la presencia de importantes efectivos militares viviendo sobre el terreno, la incidencia de las confiscaciones y composiciones pecuniarias, la introducción de un nuevo sistema fiscal y una nueva organización administrativa, lo cual lleva, por ejemplo, a problemas de competencias sobre elabastecimiento triguero que no hacían sino empeorar la situación (Algunas de estas cuestiones en Carme PEREZ APARICIO: De l'alcament maulet al triomf botifler. Eliseu Climent, editor, Valencia, 1981, pp. 91-136. Véase también José Miguel PALOP RAMOS: Hambre y lucha antifeudal. Las crisis de subsistencias en Valencia (siglo XVIII). Siglo XXI, Madrid, 1977 , pp. 73 y ss.).

(150) En el mismo sentido apuntan los datos disponibles sobre Alicante: fallecieron 3.500 paisanos y 6.000 soldados ingleses entre septiembre de 1707 y julio de 1708 a causa de la epidemia (Rafael VIRAVENS PASTOR: Op. cit., p. 290).

(151) Doc. cit. supra n. 140.

(152) Francisco BUSTELO GARCLA DEL REAL: «El vecindario general de España de 171217 o Censo de Campoflorido". Revista Internacional de Sociología (Madrid), 7-8 (1973), pp. 83-103 y 11-2 (1974), pp. 7-35.

(153) Primitivo J. PLA ALBEROLA: «La población alicantina en los siglos XVI al XVIII», en Antonio MESTRE SANCHIS (dir.): Historia de la provincia de Alicante, vol. IV. Ed. Mediterráneo, Murcia, 1986, pp. 26-27.

(154) Como pueden ser un descenso de los nacimientos por la separación provisional de las familias o un retraso en la edad al contraer matrimonio las mujeres debido a las dificultades coyunturales del momento.

(155) A.N.C.: Protocolos de Roque Reig, vol. 1708-1710, año 1708, ff. ${ }^{\circ}$ 8-9. A.M.C.: Consells, 18, ff. $^{\circ} 355-366$.

(156) Agradezco estas noticias a D. ${ }^{a}$ Mila Insa Ribelles, quien prepara un estudio sobre las confiscaciones a los austracistas de Cocentaina, del que ya adelantó algunos planteamientos en su comunicación «La Guerra de Sucesión en Cocentaina: los austracistas». Actas de las II Jornadas de Metodología y Didáctica de la Historia. Historia Moderna. Cáceres, 1983, pp. 377-387.

(157) Algunos ejemplos en Henry KAMEN: La Guerra..., pp. 398-399.

(158) A.M.C.: Cartas y órdenes, $1, \mathrm{f} .{ }^{\circ} 157 \mathrm{r} .^{\circ}$.

(159) A.M.C.: Real equivalente, 1 , sin foliar.

(160) A.M.C.: Consells, 18, respectivamente ff. $0^{\circ} 98 \mathrm{v} .^{\circ}-99 \mathrm{v} .^{\circ}, 114 \mathrm{v} .^{\circ}, 137 \mathrm{v} .^{\circ}$ y $155 \mathrm{r} .^{\circ}-156$ 
r. ${ }^{\circ}$. El citar, en concreto, estos ejemplos es por coincidir con afios dificiles bastante generalizados (Vicente PEREZ MOREDA: Op. cit., p. 307. Pierre GOUBERT: Beauvais...,pp. 45 y ss).

(161) A.M.C.: Consells, 15, ff. ${ }^{\circ} 760 \mathrm{r}^{\circ}-761 \mathrm{r} .^{\circ}, 777 \mathrm{v} .^{\circ}-778 \mathrm{r} .^{\circ}$ y $793 \mathrm{v} .^{\circ}$.

(162) En repetidas ocasiones se ha puesto de relieve que los precios del trigo registran en Valencia menores oscilaciones que en otras áreas peor comunicadas; circunstancia atribuible a la importancia que en el abasto del reino tiene la importación por vía marítima. El trabajo fundamental sobre los precios valencianos, aunque referido al siglo XVIII, es el de José Miguel PALOP RAMOS: Fluctuaciones de precios y abastecimiento en la Valencia del siglo XVIII. Institución Alfonso el Magnánimo, Valencia, 1977, $330 \mathrm{pp}$. Aparte, es obligada la consulta de los datos de Earl J. HAMILTON: (El tesoro americano y la revolución de los precios en España, 1501-1650. Ariel, Barcelona, 1975, 462 pp. Véase también James CASEY: Op. cit., pp. 42-43).

(163) A.M.C.: Cort del procurador, 1623 , «memorials», ff. $.^{\circ} 7 \mathrm{r}^{\circ}-10 \mathrm{v} .^{\circ}$.

(164) Ibid., f. ${ }^{\circ} 36 \mathrm{r}^{\circ}$.

(165) Ibíd., f. ${ }^{\circ} 31 \mathrm{r}^{\circ}$ y v$^{\circ}$ (13 de septiembre de 1623). El aludir a esas enfermedades es para justificar la excarcelación del médico. Pese a las protestas del síndico de la villa, el gobernador concede al médico un permiso de cuatro horas diarias para poder visitar a los enfermos que requieren sus servicios.

(166) A.R.V.: Real Audiencia, Procesos, 1/C/614.

(167) Ibid. Los problemas de salubridad pública ocasionados por las aguas estancadas han sido abordados por una serie de interesantes trabajos, entre ellos el de Armando ALBEROLA ROMA: «Una enfermedad de carácter endémico en el Alicante del XVIII: las fiebres tercianas», publicado en esta misma revista, donde se puede encontrar referencia a una bibliografía más amplia.

(168) A.M.C.: Consells, 12 , ff.$^{\circ} 261$ v. $.^{\circ}-262$ r. $^{\circ}, 270$ r. ${ }^{\circ}, 281$ r. $^{\circ}, 282$ r. ${ }^{\circ}$ y v. ${ }^{\circ}, 298$ v. ${ }^{\circ}-299$ r. ${ }^{\circ}$ y $300 \mathrm{r} .{ }^{\circ}-301 \mathrm{r} .^{\circ}$. Los resultados del registro domiciliario de las reservas de grano en A.M.C.: Jurats, 1651-1652, «provisions», sin foliar. El hecho de que se encuentren 16 cahíces de trigo y 148 de maíz es un buen exponente de la importancia que tenía este cereal en los momentos de dificultades.

(169) Pierre GOUBERT: Beauvais..., pp. 75-76.

(170) A.M.C.: Consells, 5, f. $^{\circ} 242 \mathrm{r}^{\circ}$ y v. ${ }^{\circ}$.

(171) «Ni es menos de considerar el compás que naturaleza va guardando en fructificar y dar de comer a los de este reyno; pues para que no puedan perecer, quando en la una parte estrema del se va acabando el pan de la cosecha vieja, en la otra del otro cabo, azia lo de Alicante, Origuela y Elche, adelanta la sazón de la nueva; de suerte que siegan cevadas y trigos por abril y mayo. Y derribados éstos en una y otra parte, suceden las cosechas de la adaças y maíz. Y todo el año se anda sin intermissión cogiendo ya unos panes ya otros, lo que basta para el sustento ordinario (Gaspar ESCOLANO: Década primera de la historia de la insigne y coronada ciudad y reyno de Valencia. Valencia, 16101611 -facsimil, Departamento de Historia Moderna, Valencia, 1972-, lib. IV, col. 673).

(172) Vicente PEREZ MOREDA: Op. cit., pp. 316 y ss.

(173) José Miguel PALOP RAMOS: Fluctuaciones..., pp. 38-40.

(174) James CASEY: Op. cit., p. 43.

(175) A.M.C.: Consells, 9, f. ${ }^{\circ} 32$ (25 de noviembre de 1607).

(176) Earl J. HAMILTON: El tesoro..., p. 402. 
APÉNDICE GRÁFICO 








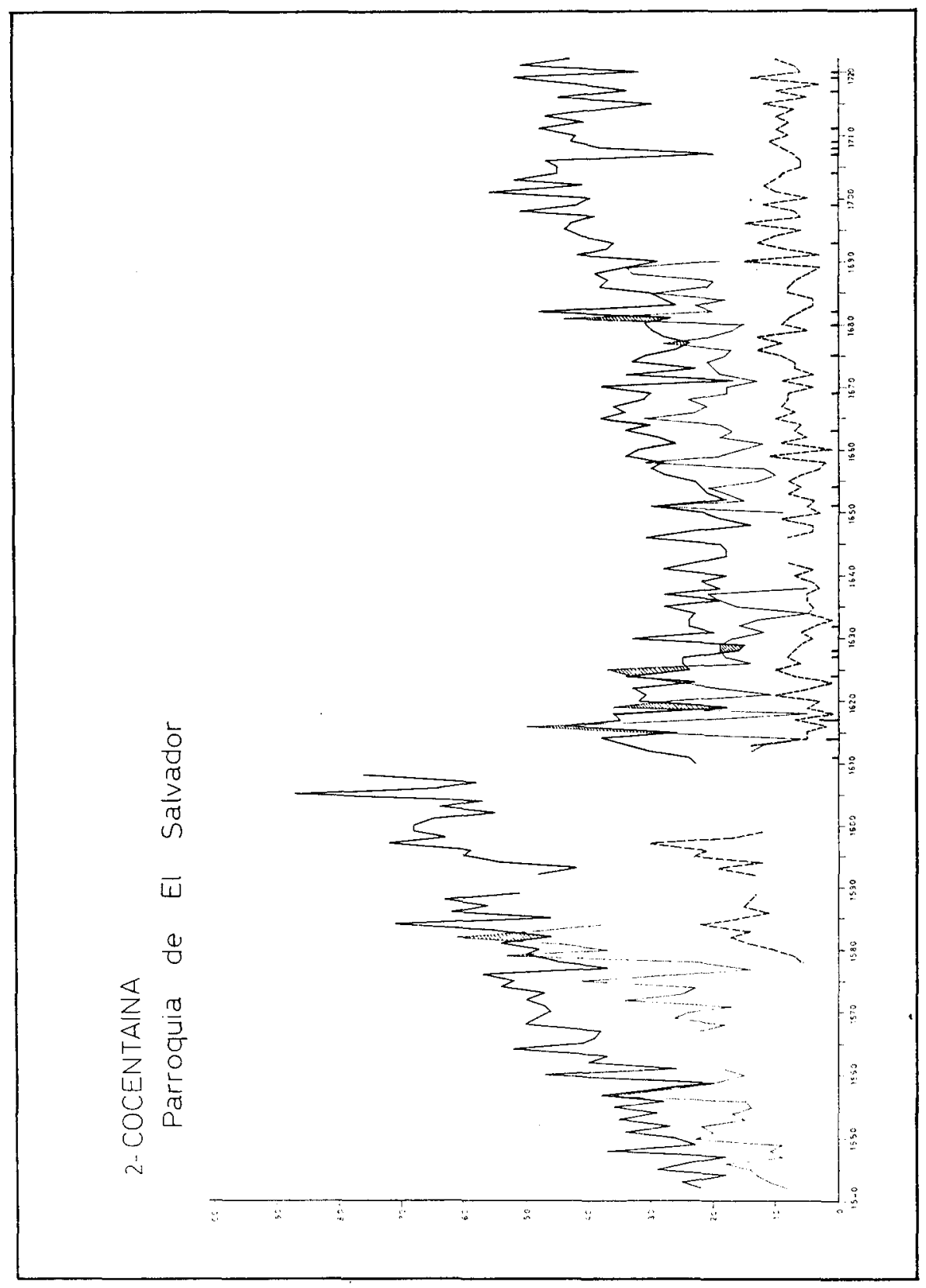


3-
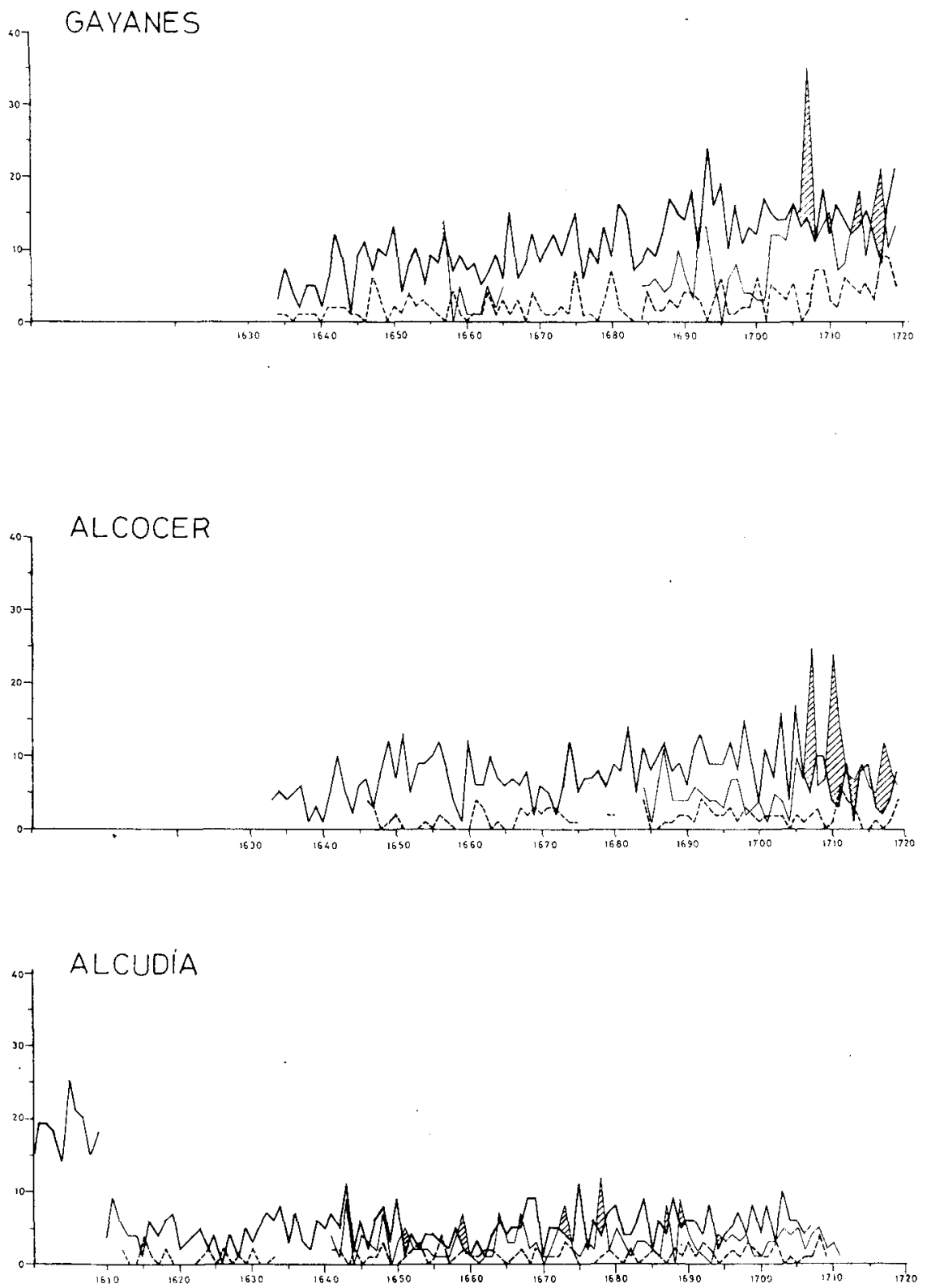


\section{4-MEDIAS ANUALES DE BAUTISMOS POR DECENIOS MONTADOS.}

Alcocer

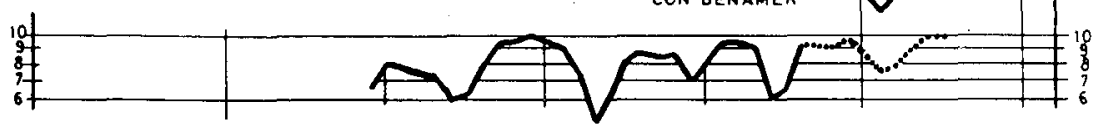

Alcudia
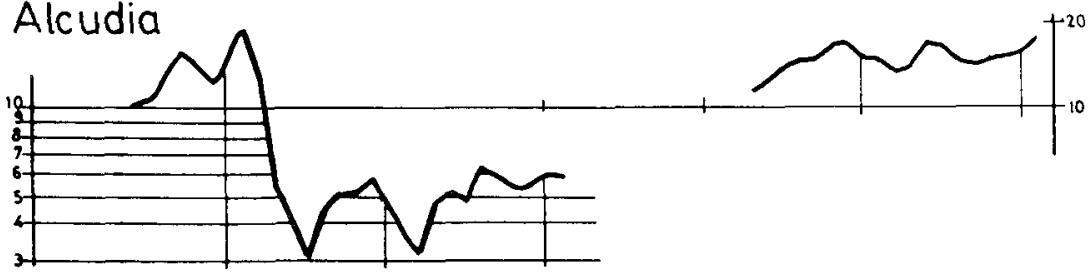

Cocentaina

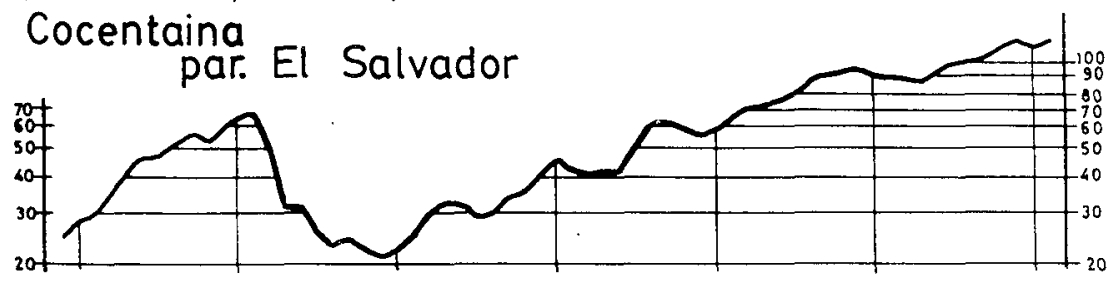

Cocentaina

par. Santa María

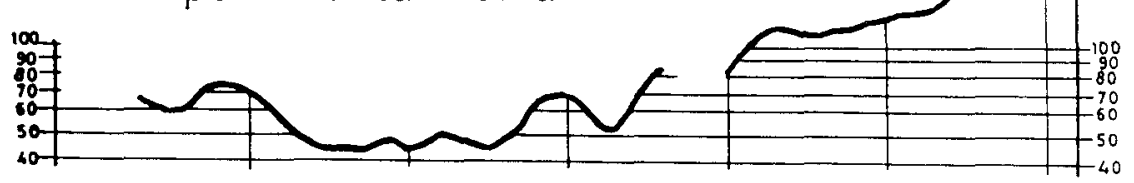

Gayanes

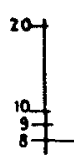

$\frac{1}{1550}$

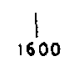

$\frac{1}{1650}$

$\int_{1700}^{1}$

1750

$\frac{1}{1800}$

1850 


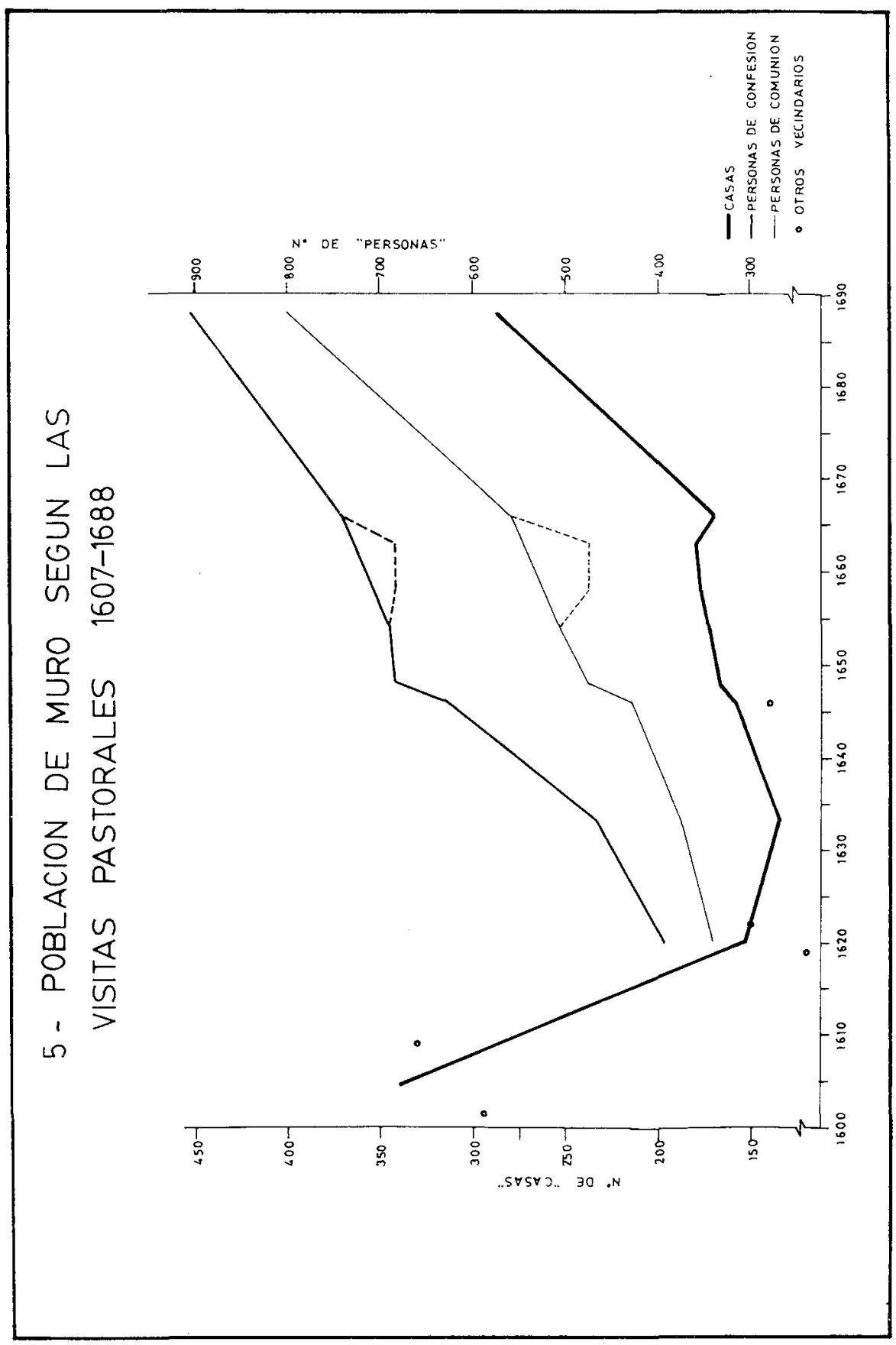




\section{6 -CRISIS DE 1701 Y 1703.}
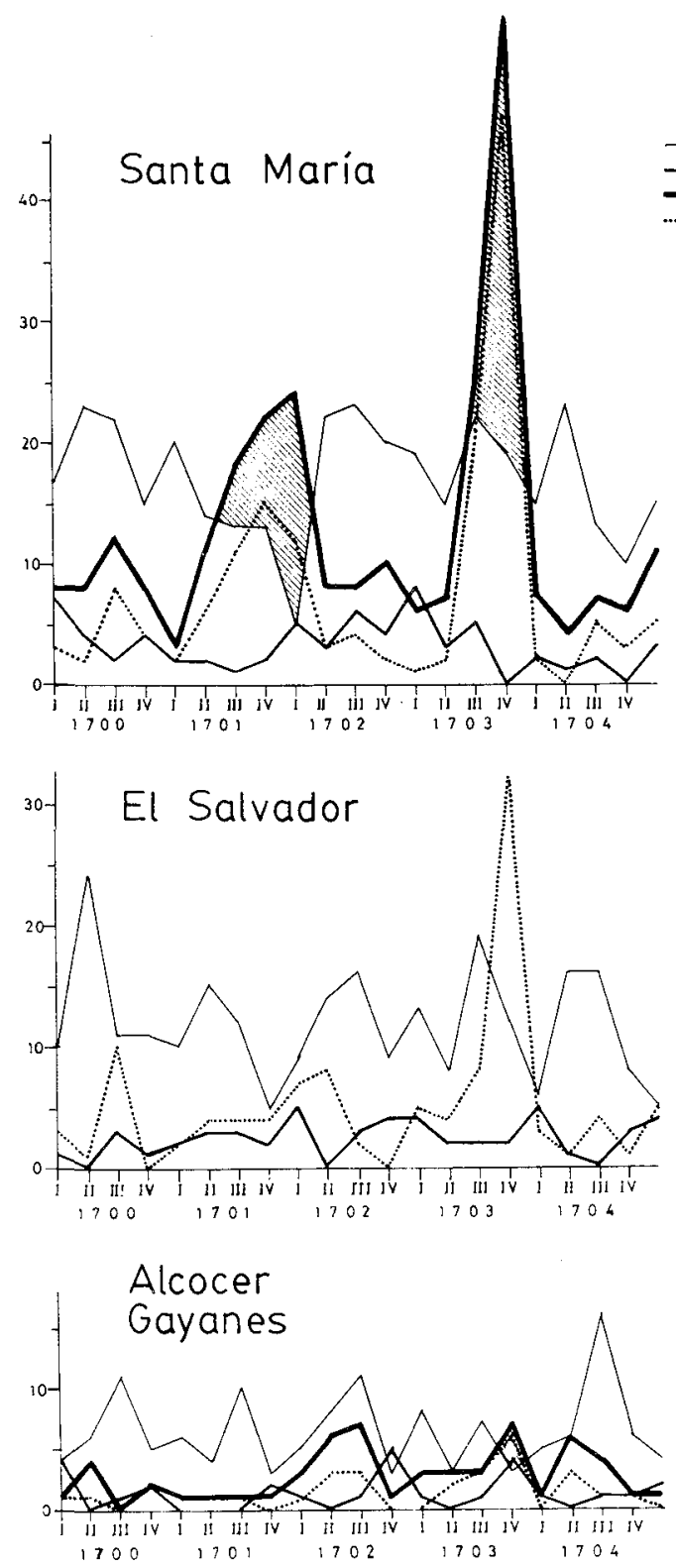


\section{7 -CRISIS DE 1706-1708.}
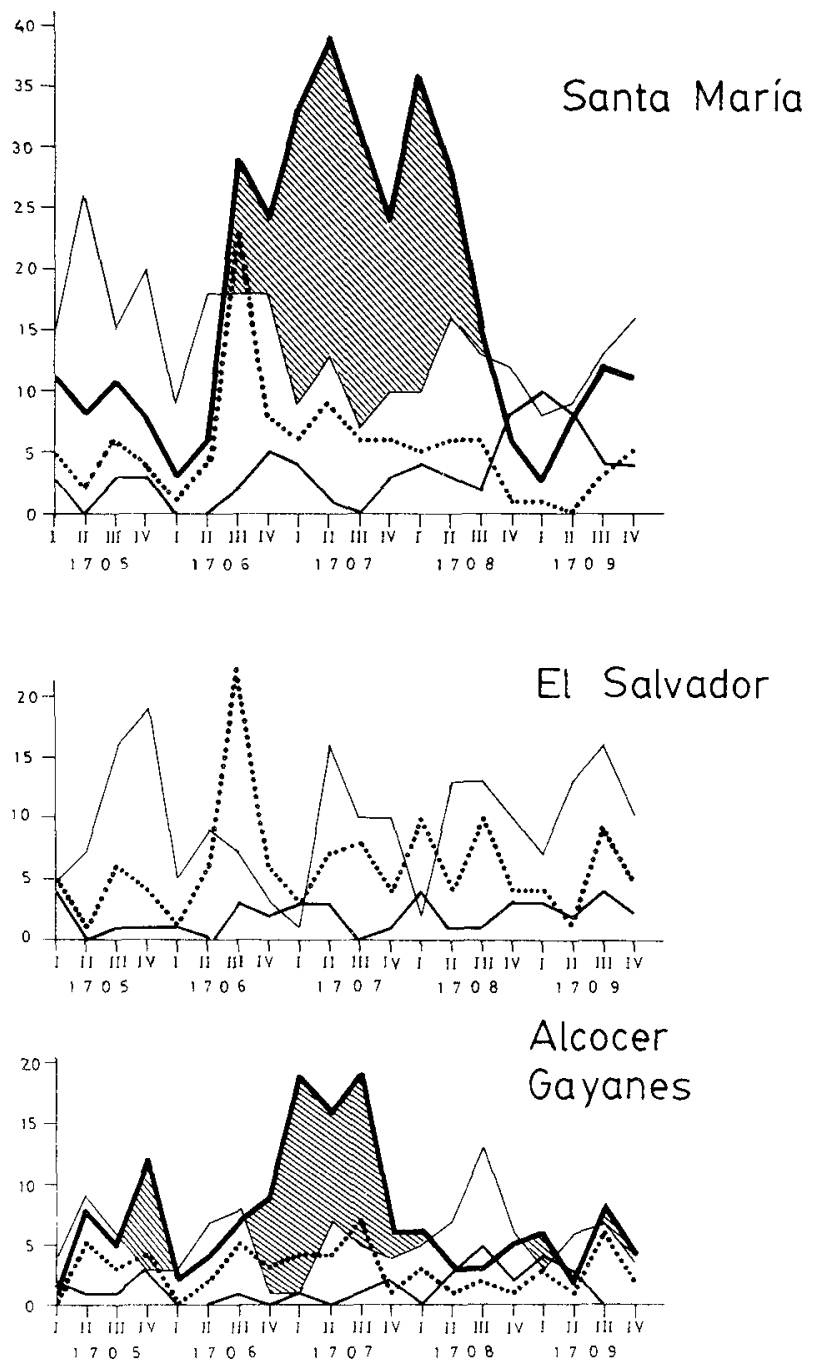

APÉNDICE ESTADÍSTICO 



\section{OBSER VACIONES SOBRE LAS FUENTES}

Aunque sin pretender sustituir un estudio de la significación y fiabilidad de los registros parroquiales -en concreto, de los del condado de Cocentaina-, considero oportuno hacer algunas advertencias sobre las series que sustentan el presente trabajo y que ofrezco a continuación.

En la parroquia de El Salvador no es posible certificar la acuracidad de los datos de defunciones de moriscos (hasta 1609) sin un análisis nominal, porque la brevedad de las actas no permite determinar, por ejemplo, la proporción de difuntos albats o si están inscritos los enterrados amore Dei. Entre diciembre de 1599 y 1609 quien registra las actas de matrimonio anota las fechas de las amonestaciones, pero no la del desposorio; al incluir también las amonestaciones de aquellos que contraen matrimonio en otras parroquias - sin poder discernir siempre ambos casos- he preferido no presentar esos datos.

La parroquia de Santa María sólo conserva el registro de difuntos adultos desde 1668. Para fechas anteriores es posible reconstruir el total anual a partir de unos índices elaborados a principios del siglo XIX; pero, al desconocer su distribución por meses, no podemos calcular el número de difuntos por año-cosecha.

Los registros de las parroquias de Alcocer y Gayanes conservan actas desde principios de la década de los veinte del XVII, aunque su discontinuidad y estado de conservación aconsejan no tomarlas en consideración hasta 1634.

Los datos seguidos por un asterisco deben ser tomados con ciertas reservas por el riesgo de que subestimen la realidad, por la posibilidad de incluir pequeñas lagunas temporales.

El guión indica la ausencia de datos; en las series por año civil, el «O» significa que el registrador anota, de forma explícita, que no se produjeron sucesos en ese año o también que están inscritas otras actas -caso de actas de amonestaciones en los libros de matrimonio o de misas testamentarias en los de sepulturasque evidencian la continuidad del registro. De todas formas, en las series de las pequeñas parroquias cuyo número de actas habitual es reducido, la ausencia de datos (-) en un año aislado no cabe identificarla con una laguna en el registro. 
BAUTISMOS, MATRIMONIOS Y SEPULTURAS POR AÑO CIVIL (A) Y CONCEPCIONES, MATRIMONIOS $Y$ SEPUITURAS POR AÑNO COSECHA (B) EN LAS PARROQUIAS DEL CONDADO DE COCENTAINA

1. Partoquias de El Salvador y Santa Maria de Cocentaina y La Alcudia

LI. SAI.VAIOR

SANTA MARIA

LA ALCUDIA

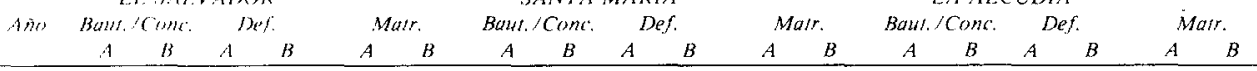

\begin{tabular}{|c|c|c|c|c|c|c|c|c|c|c|c|c|c|c|c|c|c|c|}
\hline 1541 & $\cdots$ & 24 & - & - & - & - & - & - & - & - & - & - & - & - & - & - & - & - \\
\hline 1542 & 22 & 18 & 8 & 13 & - & - & - & - & - & $\ldots$ & - & - & - & - & - & - & - & - \\
\hline 1543 & 25 & 24 & 11 & 8 & - & - & - & - & - & - & - & - & - & - & - & $-\cdots$ & - & - \\
\hline 1544 & 18 & 30 & 13 & 13 & - & - & - & - & - & - & - & - & - & - & - & - & - & - \\
\hline 1545 & 29) & 21 & 14 & 19 & - & - & - & - & - & - & - & - & - & - & - & - & - & - \\
\hline 1546 & 24 & 23 & 18 & 11 & - & - & - & - & - & - & - & - & - & - & - & - & - & - \\
\hline 1547 & 18 & 34 & 9 & 11 & - & - & - & - & - & - & - & - & - & - & - & - & - & - \\
\hline 1548 & 37 & 19 & 11 & 14 & - & - & - & - & - & - & - & - & - & - & - & - & - & - \\
\hline 1549 & 23 & 32 & 9 & 8 & - & -- & $\cdots$ & - & - & - & - & - & - & - & - & - & - & - \\
\hline 1550 & 26 & 31 & 23 & 27 & - & - & - & - & - & - & - & - & - & - & - & - & - & - \\
\hline 1551 & 34 & 31 & 20 & 17 & - & - & - & - & - & - & - & 一 & - & - & - & - & - & - \\
\hline 1552 & 27 & 31 & 22 & 20 & - & - & - & - & - & - & - & - & - & - & - & - & - & - \\
\hline 1553 & 35 & 36 & 15 & 17 & - & - & - & - & $\ldots$ & - & - & 一 & - & - & - & - & - & - \\
\hline 1554 & 29 & 26 & 17 & 15 & $\ldots$ & - & - & - & - & - & - & - & - & - & - & - & - & - \\
\hline 1555 & 36 & 3.3 & 14 & 18 & - & - & - & - & - & - & - & - & - & - & - & - & - & - \\
\hline 1556 & 28 & 32 & 15 & 14 & - & - & - & - & - & - & - & - & - & - & - & - & - & - \\
\hline 1557 & 38 & 28 & 37 & 45 & - & - & - & - & - & - & - & - & - & - & - & - & - & - \\
\hline 1558 & 28 & 32 & 27 & 24 & - & - & - & 60 & - & - & - & - & - & - & - & - & - & - \\
\hline 1559 & 20 & 38 & 20 & 15 & - & - & 56 & 54 & - & - & - & - & - & - & - & - & - & - \\
\hline 1560 & 47 & 34 & 15 & 12 & - & - & 53 & 75 & - & - & - & - & - & - & - & - & - & - \\
\hline 1561 & 26 & 44 & 18 & $17^{\prime}$ & - & - & 73 & 75 & - & - & - & - & - & - & - & - & - & -- \\
\hline 1562 & 40 & 27 & 6? & $4^{\prime}$ & - & - & 77 & 71 & - & - & - & - & - & - & - & - & - & - \\
\hline 1563 & 37 & 58 & $5^{\prime}$ & $5^{\prime}$ & - & - & 69 & 75 & - & - & - & - & - & - & - & - & - & - \\
\hline 1564 & 52 & 38 & $3^{\prime}$ & $2^{\prime}$ & - & - & 74 & 66 & - & - & - & - & - & - & - & - & - & - \\
\hline 1565 & 41 & 38 & $3^{\prime}$ & $4^{\prime}$ & - & - & 65 & 71 & - & - & - & - & - & - & - & - & - & - \\
\hline 1566 & 39 & 45 & $7^{\prime}$ & $21^{\circ}$ & - & - & 74 & 75 & - & - & - & - & - & 13 & سم- & - & - & - \\
\hline 1567 & 38 & 44 & 22 & 15 & - & - & 71 & 70 & - & - & - & - & 9 & 14 & - & - & - & - \\
\hline 1568 & 50 & 54 & 18 & 25 & - & - & 69 & 69 & - & - & - & - & 15 & 10 & - & - & - & - \\
\hline 1569 & 48 & 46 & 26 & 26 & - & - & 62 & 69 & - & - & - & - & 7 & 10 & - & - & - & - \\
\hline
\end{tabular}

$\begin{array}{rrrlllllllllllllllll}1570 & 46 & 51 & 24 & 17 & - & - & 74 & 57 & - & - & - & - & 13 & 9 & - & - & - & - \\ 1571 & 47 & 47 & 17 & 21 & - & - & 66 & 64 & - & - & - & - & 10 & 12 & - & - & - & - \\ 1572 & 50 & 47 & 34 & 34 & - & - & 57 & 59 & - & - & - & - & 8 & 5 & - & - & - & - \\ 1573 & 47 & 56 & 25 & 23 & - & - & 67 & 65 & - & - & - & - & 9 & 11 & - & - & - & - \\ 1574 & 54 & 46 & 23 & 35 & - & - & 63 & 53 & - & - & - & - & 10 & 8 & - & - & - & - \\ 1575 & 52 & 52 & 41 & 26 & - & - & 57 & 56 & - & - & - & - & 11 & 14 & - & - & - & - \\ 1576 & 57 & 35 & 27 & 25 & - & - & 54 & 68 & - & - & - & - & 10 & 16 & - & - & - & - \\ 1577 & 37 & 56 & 14 & 24 & - & - & 70 & 57 & - & - & - & - & 18 & 3 & - & - & - & - \\ 1578 & 45 & 50 & 22 & 27 & 6 & 3 & 55 & 61 & - & - & - & - & 4 & 13 & - & - & - & - \\ 1579 & 50 & 42 & 53 & 45 & 7 & 12 & 59 & 52 & - & - & - & - & 13 & 18 & - & - & - & - \\ & & & & & & & & & & & & & & & & & - \\ 1580 & 48 & 56 & 37 & 40 & 10 & 7 & 59 & 71 & - & - & 13 & 13 & 11 & 14 & - & - & - & - \\ 1581 & 54 & 53 & 44 & 49 & 14 & 20 & 52 & 72 & - & - & 17 & 18 & 18 & 19 & - & - & - & - \\ 1582 & 46 & 50 & 61 & 54 & 17 & 18 & 85 & 64 & - & - & 23 & 25 & 17 & 15 & - & - & - & - \\ 1583 & 55 & 74 & 48 & 49 & 14 & 17 & 64 & 82 & - & - & 10 & 1 & 17 & 13 & - & - & - & - \\ 1584 & 71 & 44 & 38 & 27 & 22 & 15 & 79 & 78 & - & - & 9 & 13 & 11 & 18 & - & - & 5 & 4 \\ 1585 & 46 & 64 & 37 & 45 & 16 & 15 & 67 & 88 & - & - & 18 & 17 & 12 & 21 & - & - & 2 & 5 \\ 1586 & 62 & 57 & 38 & 37 & 11 & 14 & 89 & 68 & - & - & 15 & 16 & 24 & 16 & - & - & 5 & 4 \\ 1587 & 56 & 65 & 19 & 19 & 15 & 12 & 73 & 80 & - & - & 19 & 18 & 21 & 13 & - & - & 5 & 3 \\ 1588 & 63 & 47 & 25 & 24 & 14 & 17 & 76 & 66 & - & - & 11 & 9 & 13 & 12 & - & - & 2 & 3 \\ 1589 & 51 & - & 30 & - & 13 & - & 82 & 80 & - & - & 14 & 19 & 13 & 11 & - & - & 3 & 6\end{array}$


EL SALV VADOR

SANTA MARIA

LA ALCUDIA

Año BautllConc. Def. Matr. Baut./Conc. Def.

Matr. Baut./Conc. Def

\begin{tabular}{|c|c|c|c|c|c|c|c|c|c|c|c|c|c|c|c|c|c|c|}
\hline \multirow[b]{2}{*}{ (2) } & \multicolumn{2}{|c|}{ ( } & & & & & & & & \\
\hline & $A$ & $B$ & $A$ & $B$ & $A$ & $B$ & $A$ & $B$ & $A$ & $B$ & $A$ & $B$ & $A$ & $B$ & A & $B$ & $A$ & $B$ \\
\hline 1590 & - & 36 & - & - & - & - & 73 & 81 & - & - & 12 & 15 & 12 & I 4 & - & - & 6 & 3 \\
\hline 1591 & 48 & 44 & - & - & - & - & 79 & 70 & - & - & 15 & 10 & 11 & 11 & - & $\rightarrow$ & 3 & 4 \\
\hline 1592 & 42 & - & - & $m$ & 13 & 15 & 73 & 73 & - & - & 13 & 18 & 14 & 15 & - & - & 3 & 0 \\
\hline 1593 & 54 & - & - & - & 19 & 15 & 69 & 81 & - & - & 21 & 28 & 12 & 14 & - & - & 6 & 7 \\
\hline 1594 & - & 58 & - & - & 12 & 19 & 77 & 69 & - & - & 24 & 13 & 11 & 14 & - & - & 4 & 4 \\
\hline 1595 & 60 & 63 & - & - & 23 & 23 & 78 & 81 & - & - & 24 & 30 & 18 & 14 & - & - & 2 & 6 \\
\hline 1596 & 59 & 72 & - & - & 21 & 26 & 73 & 78 & - & - & 18 & 13 & II & $11^{\prime}$ & - & - & 8 & 3 \\
\hline 1597 & 72 & 69 & - & - & 30 & 25 & 80 & 84 & - & - & 10 & 10 & $12^{\prime}$ & 12 & - & - & $6^{\prime}$ & $13^{\circ}$ \\
\hline 1598 & 63 & 64 & - & - & 17 & 10 & 87 & 66 & - & - & 14 & 10 & 17 & 11 & - & - & $8^{\prime}$ & $2^{\circ}$ \\
\hline 1599 & 68 & 71 & - & - & 12 & - & 62 & 73 & سـ & - & 13 & 19 & 8 & 19 & - & - & $4^{\prime}$ & 4 \\
\hline
\end{tabular}

$\begin{array}{lllllllllllllllllll}1600 & 68 & 59 & - & - & - & - & - & 81 & 65 & - & - & 17 & 12 & 15 & 19 & - & - & 4\end{array}$

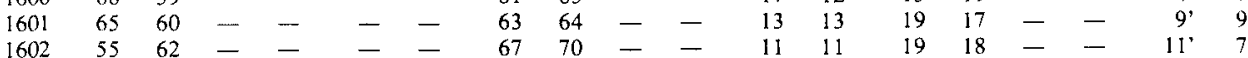

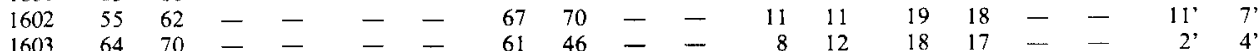

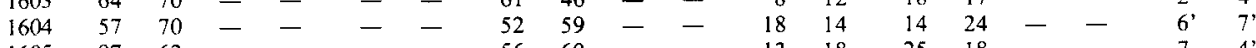

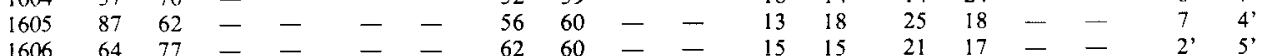

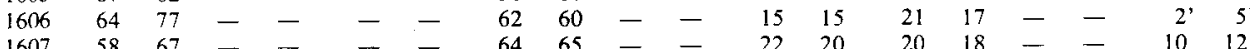

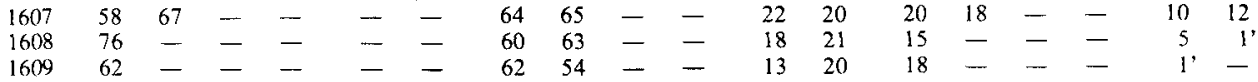

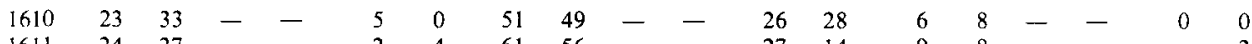

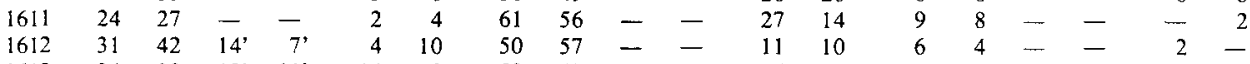

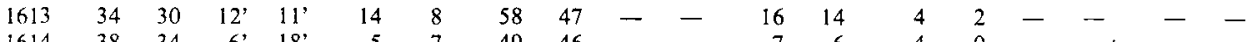

$\begin{array}{rrrrrrrrrrrrrrrr}1614 & 38 & 34 & 6 & 18 & 5 & 7 & 49 & 46 & - & - & 7 & 6 & 4 & 0 & - \\ 1615 & 26 & 37 & 31 & 47 & 5 & 3 & 40 & 55 & - & - & 12 & 18 & 1\end{array}$

$\begin{array}{rrrrrrrrrrrrrrrrrr}1615 & 26 & 37 & 31 & 47 & 5 & 3 & 40 & 55 & - & - & 12 & 18 & 1 & 8 & - & - & 4 \\ 1616 & 44 & 34 & 50 & 32 & 2 & 4 & 53 & 41 & - & - & 13 & 6 & 6 & 5 & - & -\end{array}$

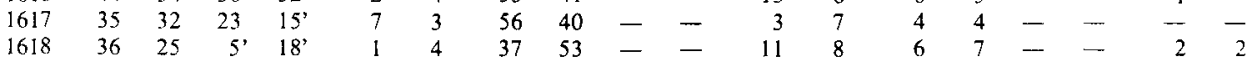

$\begin{array}{rrrrrrrrrrrrrrrrrrrr}169 & 18 & 30 & 36 & 34 & 5 & 4 & 49 & 39 & - & - & 9 & 12 & 7 & 2 & -\end{array}$

$\begin{array}{lllllllllllllllllllllll}620 & 32 & 28 & 27 & 23 & 3 & 8 & 40 & 47 & - & - & - & 9 & 9 & 2 & 6 & -\end{array}$

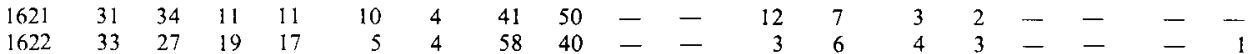

$\begin{array}{lllll}1623 & 23 & 26 & 26 & 28\end{array}$

$\begin{array}{lllll}1624 & 34 & 28 & 33 & 40\end{array}$

$\begin{array}{lllll}1625 & 24 & 26 & 37 & 26\end{array}$

$\begin{array}{lllll}1626 & 25 & 21 & 14 & 16\end{array}$

$\begin{array}{lllll}1627 & 25 & 16 & 18 & 21\end{array}$

$\begin{array}{lllll}1628 & 16 & 21 & 19 & 18\end{array}$

$\begin{array}{lllll}1629 & 15 & 31 & 19 & 14\end{array}$

$\begin{array}{lllll}1630 & 33 & 16 & 17 & 17\end{array}$

$\begin{array}{lllllll}1631 & 20 & 28 & 12 & 14 & 4 & 5\end{array}$

$\begin{array}{rrrrr}34 & 52 & - & 10 & 8 \\ 55 & 45 & - & 5 & 12\end{array}$

$\begin{array}{llllll}44 & 44 & 55 & 49 & 15 & 12\end{array}$

$\begin{array}{llllll}52 & 54 & 42 & 59 & 14 & 20\end{array}$

$\begin{array}{llllll}55 & 44 & 62 & 48 & 15 & 7\end{array}$

$\begin{array}{rrrrrr}33 & 39 & 38 & 35 & 6 & 9 \\ 40 & 49 & 33 & - & 11 & 12\end{array}$

$\begin{array}{lllll}1632 & 24 & 21 & 16 & 13\end{array}$

$\begin{array}{lllll}1633 & 24 & 28 & 13 & 12\end{array}$

$\begin{array}{lllll}56 & 45 & - & 15 & 16\end{array}$

$\begin{array}{lllll}43 & 35 & -\quad 14\end{array}$

$\begin{array}{lllll}1634 & 23 & 24 & 6 & 13\end{array}$

$\begin{array}{lllll}1635 & 28 & 24 & 16 & 15\end{array}$

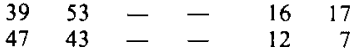

$\begin{array}{lllll}1636 & 19 & 22 & 19 & 16\end{array}$

$4646-46$

$\begin{array}{lllllll}1637 & 28 & 18 & 21 & - & 5 & 5\end{array}$

$\begin{array}{llll}1638 & 19 & 23 & -\end{array}$

$\begin{array}{lllll}43 & 47 & - & 6 & 6\end{array}$

$41 \quad 37-6-6 \begin{array}{rrr}7 & 6\end{array}$

$\begin{array}{rrrrrr}40 & 48 & - & - & 12 & 11 \\ 42 & 47 & - & - & 9 & 12\end{array}$

$\begin{array}{lllll}1639 & 22 & 21 & - & -\end{array} 4$

$\begin{array}{lllllll}1640 & 18 & 24 & - & - & 7 & 7\end{array}$

$49 \quad 49-\quad-\quad 15 \quad 10$

$\begin{array}{rrrrrrr}1641 & 28 & 23 & - & - & 4 & 2 \\ 1642 & 23 & 20 & - & - & 8 & -\end{array}$

$\begin{array}{lllllll}1643 & 18 & 17 & - & - & - & -\end{array}$

$\begin{array}{lllllll}1644 & 18 & 19 & - & - & - & - \\ 1645 & 19 & 28 & - & - & - & -\end{array}$

$\begin{array}{lllllll}1646 & 31 & 38 & - & - & 8\end{array}$

$\begin{array}{lllllll}1647 & 23 & 17 & - & - & 4\end{array}$

$\begin{array}{lllllll}1648 & 14 & 25 & - & - & 4 & 9 \\ 1649 & 19 & 20 & - & - & 9 & 4\end{array}$

$\begin{array}{rrrlrr}52 & 57 & - & - & 11 & 12 \\ 59 & 44 & - & - & 12 & 8 \\ 45 & 53 & 31 & - & 8 & 13 \\ 50 & 44 & 23 & - & 6 & 4 \\ 46 & 61 & 35 & - & 5 & 8 \\ 55 & 46 & 29 & - & 9 & 6 \\ 51 & 31 & 42 & - & 10 & 10 \\ 30 & 48 & 183 & - & 7 & 11 \\ 47 & 41 & 32 & - & 15 & 14\end{array}$


EL. SAL.VADOR

SANTA MARIA

LA ALCUDIA

Año Baut $/$ Conc. Def. Matr. Baut./Conc. Def.

Def. Matr. Buth.KOnc. Def

\begin{tabular}{|c|c|c|c|c|c|c|c|c|c|c|c|c|c|c|c|c|c|c|}
\hline & A & $B$ & $A$ & $B$ & $A$ & $B$ & $A$ & $B$ & $A$ & $B$ & $A$ & B & $A$ & $B$ & $A$ & $B$ & $A$ & $B$ \\
\hline 1650 & 22 & 28 & 9 & 22 & 3 & 6 & 44 & 46 & 24 & - & 14 & 10 & 9 & 3 & 3 & 3 & - & - \\
\hline 1651 & 30 & 17 & 29 & 21 & 5 & 5 & 46 & 37 & 68 & - & 7 & 7 & $l$ & 2 & 5 & 5 & 1 & 1 \\
\hline 16552 & 18 & 23 & 15 & 17 & 4 & 3 & 34 & 48 & 15 & - & 7 & 8 & 4 & 4 & 2 & 2 & 2 & 3 \\
\hline 1653 & 21 & 20 & 18 & 23 & 8 & 6 & 44 & 44 & 35 & - & 7 & 12 & 2 & 2 & 2 & 1 & 3 & 2 \\
\hline 1654 & 22 & 21 & $2 I$ & 17 & 6 & 10 & 49 & 49 & 30 & - & 12 & 8 & 4 & 6 & 2 & 2 & - & - \\
\hline 1655 & 23 & 31 & 13 & 4 & 8 & 5 & 47 & 38 & 19 & - & 11 & 14 & 4 & 1 & - & i & 1 & 3 \\
\hline 16.56 & 28 & 33 & 10 & 12 & 6 & 6 & 44 & 64 & 25 & - & 12 & 11 & 3 & 5 & 1 & 1 & 4 & 2 \\
\hline 1657 & 30 & 26 & 12 & 18 & 3 & 3 & 55 & 42 & 22 & - & 9 & 4 & 2 & 3 & 1 & 2 & 0 & 0 \\
\hline 1658 & 28 & 39 & 31 & 27 & 2 & 5 & 49 & 59 & 50 & - & 7 & 12 & 5 & 2 & 4 & 6 & 1 & 1 \\
\hline 1659 & 34 & 29 & 19 & 26 & 11 & 8 & 56 & 50 & 42 & - & 11 & 11 & 2 & 0 & 7 & 4 & 2 & 3 \\
\hline
\end{tabular}

$\begin{array}{rrrrrrrrrrrrrrrrrrrrrrr}1660 & 32 & 25 & 16 & 6 & 1 & 5 & 47 & 47 & 40 & - & 11 & 13 & 1 & 3 & 1 & 0 & 1 & 1 \\ 1661 & 26 & 36 & 12 & 21 & 9 & 6 & 45 & 49 & 26 & - & 10 & 9 & 3 & 1 & 0 & 0 & 1 & 1 \\ 1662 & 29 & 29 & 19 & 18 & 5 & 7 & 51 & 60 & 36 & - & 11 & 13 & 1 & 7 & 1 & 2 & 2 & 2 \\ 1663 & 34 & 33 & 17 & 15 & 7 & 5 & 65 & 49 & 29 & - & 16 & 12 & 4 & 3 & 1 & 4 & 2 & 2 \\ 1664 & 30 & 33 & 19 & 32 & 6 & 6 & 46 & 48 & 36 & - & 9 & 9 & 6 & 5 & 7 & 4 & 1 & 0 \\ 1665 & 38 & 28 & 31 & 22 & 10 & 11 & 44 & 49 & 62 & - & 12 & 12 & 4 & 4 & 3 & 2 & 0 & 0 \\ 1666 & 34 & 48 & 23 & 19 & 7 & 10 & 55 & 53 & 67 & - & 10 & 16 & 5 & 11 & 3 & 6 & 1 & 3 \\ 1667 & 36 & 22 & 21 & 24 & 9 & 8 & 57 & 41 & 24 & - & 14 & 8 & 5 & 4 & 7 & 4 & 2 & 0 \\ 1668 & 31 & 40 & 24 & 22 & 8 & 8 & 29 & 48 & 56 & - & 9 & 11 & 9 & 8 & 2 & 4 & 0 & 1 \\ 1669 & 30 & 28 & 18 & 14 & 8 & 5 & 51 & 51 & 35 & 41 & 11 & 14 & 9 & 4 & 3 & 1 & 2 & 2\end{array}$

$\begin{array}{lllllllllllll}1670 & 38 & 18 & 18 & 16 & 4 & 6 & 47 & 28 & 27 & 27 & 16 & 13\end{array}$

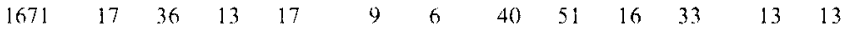

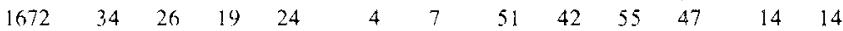

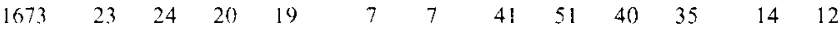

$\begin{array}{rrrrrrrrrrrrr}1674 & 33 & 36 & 21 & 17 & 7 & 8 & 46 & 47 & 33 & 37 & 12 & 18 \\ 1679 & 31 & 28 & 18 & 18 & 9 & 15 & 44 & 42 & 33 & 22 & 14 & \end{array}$

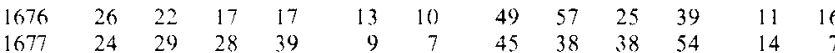

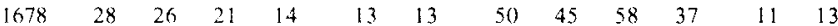

$\begin{array}{llllllllllll}1679 & 30 & 37 & 17 & 15 & 5 & 7 & 41 & 53 & 24 & 33 & 14\end{array}$

$\begin{array}{rllllllllllllllllll}1680 & 31 & 29 & 15 & 21 & 9 & 10 & 53 & 37 & 48 & 45 & 12 & 13 & 8 & 4 & 5 & 7 & 1 & 1 \\ 1681 & 27 & 41 & 44 & 34 & 8 & 6 & 45 & 56 & 59 & 49 & 16 & 15 & 4 & 6 & 3 & 0 & 0 & 1 \\ 1682 & 48 & 22 & 20 & 23 & 6 & 5 & 53 & 36 & 37 & 43 & 11 & 9 & 4 & 5 & 1 & 1 & 2 & 1 \\ 1683 & 26 & 38 & 23 & 24 & 4 & 5 & 41 & 52 & 32 & 34 & 7 & 11 & 6 & 8 & 3 & 3 & 0 & 0 \\ 1684 & 28 & 28 & 18 & 15 & 4 & 8 & 53 & 52 & 47 & 45 & 19 & 16 & 9 & 4 & 3 & 5 & 1 & 3 \\ 1685 & 30 & 38 & 30 & 36 & 8 & 7 & 58 & 57 & 40 & 51 & 9 & 12 & 2 & 6 & 2 & 0 & 2 & 1 \\ 1686 & 38 & 38 & 21 & 14 & 8 & 4 & 49 & 57 & 53 & 37 & 16 & 22 & 6 & 3 & 1 & 9 & 1 & 0 \\ 1687 & 37 & 34 & 20 & 27 & 7 & 6 & 58 & 65 & 33 & 35 & 21 & 16 & 4 & 9 & 8 & 0 & 0 & 0 \\ 1688 & 39 & 36 & 33 & 37 & 5 & 5 & 62 & 65 & 47 & 50 & 17 & 13 & 9 & 7 & 0 & 1 & 2 & 3 \\ 1689 & 34 & 32 & 34 & 24 & 3 & 9 & 65 & 61 & 52 & 45 & 15 & 11 & 5 & 3 & 9 & 9 & 1 & 1\end{array}$

\begin{tabular}{|c|c|c|c|c|c|c|c|c|c|c|c|c|c|c|c|c|c|}
\hline 1690 & 29 & 46 & 19 & - & 15 & 8 & 61 & 81 & 26 & 32 & 8 & 20 & 6 & 8 & 4 & 3 & 3 \\
\hline 1691 & 42 & 39 & - & - & 3 & 7 & 71 & 73 & 34 & 23 & 22 & 14 & 6 & 3 & 2 & 3 & 1 \\
\hline 1692 & 37 & 31 & - & - & 9 & 13 & 76 & 60 & 18 & 43 & 11 & 11 & 4 & 7 & ] & 0 & 3 \\
\hline 1693 & 36 & 42 & - & - & 13 & 8 & 61 & 70 & 43 & 28 & 11 & 19 & 8 & 4 & 0 & 1 & 2 \\
\hline 1694 & 41 & 46 & - & - & 10 & 11 & 71 & 68 & 42 & 42 & 18 & 14 & 2 & 2 & 4 & 3 & - \\
\hline 1695 & 44 & 41 & - & - & 6 & 7 & 80 & 66 & 39 & 44 & 12 & 13 & 4 & 6 & 3 & 5 & 1 \\
\hline 1696 & 43 & 40 & $\ldots$ & - & 15 & 15 & 58 & 65 & 46 & 43 & 16 & 16 & 5 & 6 & 4 & 2 & 2 \\
\hline 1697 & 39 & 59 & - & - & 6 & 4 & 62 & 77 & 61 & 56 & 19 & 13 & 7 & 7 & 3 & 5 & 1 \\
\hline 1698 & 51 & 28 & - & - & 7 & 11 & 80 & 60 & 34 & 35 & 9 & 17 & 4 & 5 & 4 & 2 & 3 \\
\hline 1699 & 42 & 55 & - & - & 12 & 6 & 62 & 72 & 43 & 45 & 21 & 21 & 8 & 6 & 1 & 2 & 2 \\
\hline 1700 & 40 & 47 & - & - & 5 & 9 & 67 & 71 & 36 & 34 & 18 & 10 & 4 & 6 & 1 & 1 & 1 \\
\hline 1701 & 56 & 40 & - & - & 10 & 10 & 80 & 53 & 54 & 72 & 7 & 11 & 8 & 5 & 3 & 5 & 1 \\
\hline 1702 & 41 & 46 & - & - & 12 & 13 & 45 & 78 & 50 & 31 & 18 & 21 & 3 & 9 & 3 & 0 & 3 \\
\hline 1703 & 52 & 53 & - & - & 10 & 10 & 84 & 78 & 93 & 91 & 16 & 8 & 10 & 6 & 5 & 7 & $\ldots$ \\
\hline 1704 & 45 & 36 & - & - & 9 & 7 & 71 & 64 & 24 & 32 & 5 & 5 & 6 & 5 & 4 & 3 & 1 \\
\hline 1705 & 45 & 49 & - & - & 6 & 3 & 61 & 62 & 38 & 28 & 9 & 6 & 6 & 6 & 5 & 4 & - \\
\hline 1706 & 47 & 27 & - & - & 6 & 11 & 70 & 55 & 62 & 124 & 7 & 12 & 3 & 5 & 2 & 4 & 1 \\
\hline 1707 & 20 & 35 & - & - & 7 & 6 & 60 & 43 & 126 & 119 & 8 & 10 & 6 & 一 & 4 & 3 & 1 \\
\hline 1708 & 38 & 43 & - & - & 9 & 9 & 40 & 42 & 85 & 32 & 17 & 28 & 3, & $\cdots$ & 5 & 5 & 4 \\
\hline 1709 & 43 & 41 & - & - & 11 & 11 & 49 & 48 & 34 & 35 & 26 & 11 & - & - & 2 & - & 1 \\
\hline
\end{tabular}


Baut./Conc. Defunciones Matrimonios Baut./Conc. Defunciones Matrimonios

$\begin{array}{llllllllllll}\text { A } & \text { B } & \text { A } & \text { B } & \text { A } & \text { B } & \text { A } & \text { B } & \text { A } & \text { B } & \text { A } & \text { B }\end{array}$

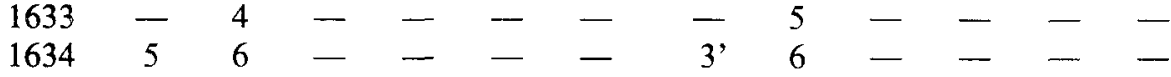

$\begin{array}{lllllllll}1635 & 4 & 4 & - & - & - & 7\end{array}$

$\begin{array}{llllllll}1636 & 5 & 5 & - & - & - & 4\end{array}$

$\begin{array}{llllllll}1637 & 6 & 1 & - & - & - & -\end{array}$

$\begin{array}{lllllll}1638 & 1 & 3 & - & - & -\end{array}$

$\begin{array}{lll}1639 & 3 & 4\end{array}$

$\begin{array}{lllllll}1640 & 1 & 7 & - & - & -\end{array}$

$\begin{array}{lllllll}1641 & 5 & 8 & - & - & -\end{array}$

$1642 \quad 10 \quad 3^{\prime}$

$1643 \quad 5 \quad 1$

$1644 \quad 2$ '

$\begin{array}{lllll}1645 & 6 & 4 & - & 2\end{array}$

26

$\begin{array}{llllll}1646 & 7 & 5 & - & - & 4\end{array}$

$\begin{array}{lllllll}1647 & 3 & 9 & - & - & 3\end{array}$

$\begin{array}{llllllll}1648 & 8 & 10 & - & - & 0 & 1 & 10\end{array}$

$1649,12 \quad 10 \quad-\quad-$

$\begin{array}{rrrllllrrrrrr}1650 & 7 & 10 & - & - & 2 & 2 & 13 & 5 & - & - & 2 & 2 \\ 1651 & 13 & 6 & - & - & 0 & 0 & 4 & 7 & - & - & 1 & 0 \\ 1652 & 5 & 13 & - & - & 0 & 0 & 8 & 11 & - & - & 4 & 4 \\ 1653 & 9 & 7 & - & - & 0 & 0 & 10 & 4 & - & - & 2 & 5 \\ 1654 & 9 & 10 & - & - & 1 & 1 & 5 & 11 & 3 & 3 & 3 & 1 \\ 1655 & 10 & 13 & - & - & 0 & 1 & 9 & 11 & 1 & - & 2 & 2 \\ 1656 & 12 & 3 & - & - & 2 & 1 & 8 & 8 & - & - & 1 & 0 \\ 1657 & 8 & 5 & - & - & 1 & 1 & 12 & 8 & 14 & 14 & 0 & 0 \\ 1658 & 4 & 5 & - & - & 0 & 0 & 7 & 9 & - & - & 4 & 5 \\ 1659 & 1 & 10 & - & - & 0 & 0 & 9 & 5 & 5 & 5 & 1 & 0\end{array}$

$\begin{array}{lllllllllllll}1660 & 12 & 4 & - & - & 0 & 3 & 7 & 8 & 1 & 1 & - & 1\end{array}$

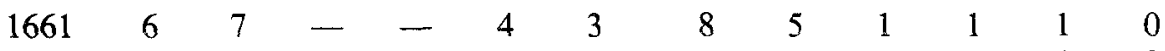

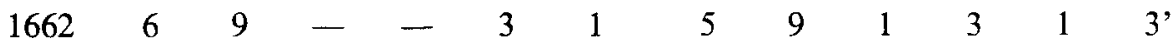
$\begin{array}{lllllllllllll}1663 & 10 & 7 & - & - & 0 & 0 & 7 & 8 & 5 & 3 & 4 & 2^{\prime}\end{array}$ $\begin{array}{lllllllllllll}1664 & 7 & 9 & - & - & 1 & 1 & 9 & 8 & 2 & 5 & 1 & 2\end{array}$ $\begin{array}{lllllllllllll}1665 & 6 & 5 & - & - & 0 & 0 & 6 & 11 & 5 & 2 & 3 & 2\end{array}$ $\begin{array}{llllllllllll}1666 & 7 & 6 & - & - & 0 & 2 & 15 & 7 & 1 & - & 1\end{array}$ $\begin{array}{llllllllllll}1667 & 6 & 6 & - & - & 3 & 6 & 11 & -\end{array}$ $\begin{array}{lllllllllll}1668 & 8 & 2 & - & 2 & 4 & 8 & 12 & - & 0 & 0\end{array}$

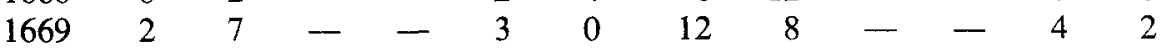


Baut./Conc. Defunciones Matrimonios

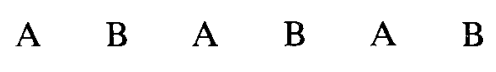

1677 1672
1673

1674

1675

1676

1677

1679

1680

$\begin{array}{llll}1681 & -9 & 9\end{array}$

$\begin{array}{lll}1682 & 14 \quad 8\end{array}$

$\begin{array}{lll}1683 & 5 & 11\end{array}$

$1684 \quad 11$

$\begin{array}{lll}1685 & 8 & 12\end{array}$

$\begin{array}{llll}1686 & 10 & 11 & 7\end{array}$

$\begin{array}{llll}1687 & 12 & 7 & 11\end{array}$

$\begin{array}{llll}1688 & 8 & 8 & 4\end{array}$

$\begin{array}{llll}1689 & 9 & 9 & 4\end{array}$

$\begin{array}{llll}1690 & 6 & 9 & 4\end{array}$

$\begin{array}{llll}1691 & 11 & 12 & 6\end{array}$

$\begin{array}{llll}1692 & 13 & 10 & 5\end{array}$

$\begin{array}{llll}1693 & 9 & 10 & 4\end{array}$

$\begin{array}{llll}1694 & 9 & 9 & 4\end{array}$

$\begin{array}{lllll}1695 & 9 & 15 & 3\end{array}$

$\begin{array}{llll}1696 & 12 & 5 & 7\end{array}$

$\begin{array}{llll}1697 & 8 & 16 & 7\end{array}$

$\begin{array}{llll}1698 & 15 & 6 & 2\end{array}$

$\begin{array}{llll}1699 & 9 & 6 & 3\end{array}$

$\begin{array}{llll}1700 & 4 & 9 & 4\end{array}$

$\begin{array}{llll}1701 & 11 & 10\end{array}$

$\begin{array}{llll}1702 & 7 & 13 & 5\end{array}$

$\begin{array}{llrr}1703 & 16 & 5 & 4\end{array}$

$\begin{array}{llll}1704 & 4 & 21 & 1\end{array}$

$\begin{array}{lllll}1705 & 17 & 1 & 10 & 6\end{array}$

$\begin{array}{lllll}1706 & 8 & 8 & 7 & 13\end{array}$

$\begin{array}{lllll}1707 & 5 & 8 & 25 & 20\end{array}$

$\begin{array}{lllllll}1708 & 10 & 12 & 6 & 4 & 3 & 2\end{array}$

$\begin{array}{lllllll}1709 & 10 & 2 & 7 & 6 & - & 0\end{array}$
Baut./Conc. Defunciones Matrimonios

$\begin{array}{llllll}\text { A } & \text { B } & \text { A } & \text { B } & \text { A } & \text { B }\end{array}$

$\begin{array}{rrrr}8 & 12-2 \\ 10 & 8 & -2\end{array}$

$\begin{array}{lllll}12 & 11 & - & 1\end{array}$

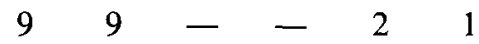

$1213--13$

$157-26$ ?

$6 \quad 11-21,1$,

$108-21,0$

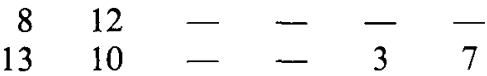

$915-274$

$1613--22$

$149--10$

$79-2-0$

$\begin{array}{llllll}8 & 8 & 5 & 4 & - & 0\end{array}$

$\begin{array}{llllll}10 & 11 & 5 & 6 & 4 & 5\end{array}$

$\begin{array}{llllll}9 & 13 & 6 & 4 & 2 & 1\end{array}$

$\begin{array}{llllll}12 & 18 & 4 & 5 & 2 & 4\end{array}$

$\begin{array}{llllll}17 & 10 & 5 & 8 & 3 & 2\end{array}$

$\begin{array}{llllll}15 & 21 & 10 & 9 & 2 & 1\end{array}$

$\begin{array}{llllll}14 & 14 & 6 & 5 & 4 & 5\end{array}$ $\begin{array}{llllll}18 & 14 & 3 & 12 & 4 & 4\end{array}$

$\begin{array}{llllll}10 & 23 & 13 & 8 & 3 & 2\end{array}$ $\begin{array}{llllll}24 & 18 & 13 & 10 & - & 2\end{array}$

$\begin{array}{llllll}16 & 12 & 5 & 2 & 3 & 3\end{array}$

$\begin{array}{llllll}19 & 12 & 0 & 2 & 6 & 5\end{array}$

$\begin{array}{llllll}10 & 15 & 6 & 5 & 1 & 0\end{array}$

$\begin{array}{llllll}16 & 10 & 8 & 10 & 1 & 1\end{array}$

$\begin{array}{llllll}11 & 16 & 4 & 2 & 2 & 2\end{array}$

$\begin{array}{llllll}13 & 9 & 4 & 6 & 2 & 6\end{array}$

$\begin{array}{llllll}12 & 17 & 3 & 2 & 6 & 2\end{array}$

$\begin{array}{llllll}17 & 16 & 3 & 7 & - & 0\end{array}$

$\begin{array}{llllll}15 & 12 & 12 & 12 & 5 & 6\end{array}$

$\begin{array}{llllll}14 & 16 & 12 & 13 & 4 & 4\end{array}$

$\begin{array}{llllll}14 & 15 & 11 & 7 & 3 & 4\end{array}$

$\begin{array}{llllll}16 & 18 & 16 & 17 & 5 & 3\end{array}$

$\begin{array}{llllll}13 & 11 & 15 & 38 & - & 1\end{array}$

$\begin{array}{llllll}14 & 13 & 35 & 14 & 2 & 3\end{array}$

$\begin{array}{llllll}11 & 15 & 11 & 12 & 7 & 12\end{array}$

$\begin{array}{llllll}18 & 13 & 13 & 12 & 7 & 1\end{array}$ 